\title{
ANTROPOLOGÍA Y HUMANISMO EN EL SOCIALISMO DEL SIGLO XXI. SUS
}

ANTECEDENTES EN EL JOVEN MARX

JAVIER DE JESÚS ROJAS ROJAS

\section{UNIVERSIDAD SANTO TOMÁS}

FACULTAD DE FILOSOFÍA Y TEOLOGÍA MAESTRÍA EN FILOSOFÍA LATINOAMERICANA BOGOTÁ 2017 


\title{
ANTROPOLOGÍA Y HUMANISMO EN EL SOCIALISMO DEL SIGLO XXI. SUS
} ANTECEDENTES EN EL JOVEN MARX

\section{JAVIER DE JESÚS ROJAS ROJAS}

Trabajo de grado como requisito para optar el título de Magister

Director:

DAMIÁN PACHÓN SOTO

\author{
UNIVERSIDAD SANTO TOMÁS \\ FACULTAD DE FILOSOFÍA Y TEOLOGÍA \\ MAESTRÍA EN FILOSOFÍA LATINOAMERICANA \\ BOGOTÁ 2017
}


El socialismo del siglo XXI tiene sus antecedentes en el joven Marx, los cuales se le articulan para hacer un socialismo adaptado a las realidades sociales y filosóficas de este

siglo. 


\section{AGRADECIMIENTOS}

A Dios Papá y Mamá, hijo Jesús, Dios hecho realidad humana sufriente en los sin nombres, Espíritu Santo, quien en Jesús actualizado en cada hoy de la historia; mi madre la compleja Iglesia Católica; mi madre Victoria y padre José, mi hermana Nancy y mis hermanos José y Ernesto, sobrinos y sobrinas; mis hermanos y hermanas y mis hijos e hijas de la vida; profesores y amigos; toda mi gente sencilla, quienes son socialismo del siglo XXI. 


\section{ANTROPOLOGÍA Y HUMANISMO EN EL SOCIALISMO DEL SIGLO XXI. SUS ANTECEDENTES EN EL JOVEN MARX}

\section{Resumen}

La antropología y humanismo del socialismo del siglo XXI es una continuación de los escritos del joven Marx. Las realidades del tiempo de Marx son distintas a las de este siglo, por lo que se tiene que pensar filosóficamente este nuevo socialismo para buscar encuentros y desencuentros de este con el joven Marx, lo cual ayuda a construir este socialismo del siglo XXI, en una dialéctica materialista constante y perfeccionadora de las realidades filosóficas y materiales.

Palabras Claves: Comunismo, Dialéctica Materialista, Joven Marx, Latinoamérica, Movimientos Sociales, Siglo XXI, Socialismo. 


\section{TABLA DE CONTENIDO}

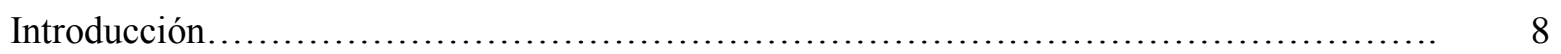

1 Antropología y humanismo en el socialismo del joven Marx.......................... 18

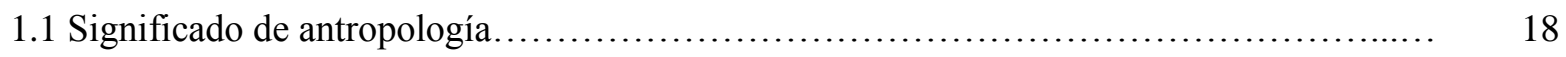

1.2 Significado de humanismo............................................... 19

1.3 Concepto de socialismo marxista........................................... 20

1.3.1 Concepto de socialismo en general........................................ 20

1.3.2 Socialismo Marxista....................................................... 22

1.4 Trabajo enajenado....................................................... 32

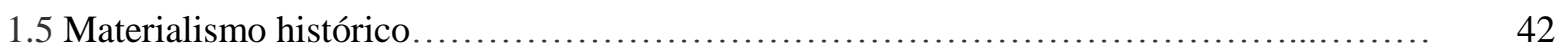

2 Antropología y humanismo en el socialismo del siglo XXI......................... 48

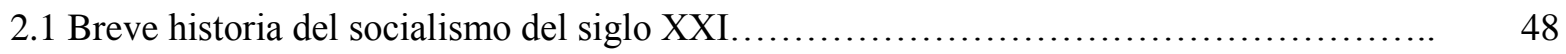

2.2 Emancipación de la mujer como signo del socialismo del siglo XXI.................. 52

2.3 Indígenas y socialismo del siglo XXI............................................... 54

2.4 Campesinas, campesinos y socialismo del siglo XXI........................... 63

2.5 Socialismo del siglo XXI y movimientos sociales.............................. 66

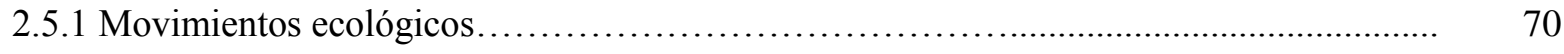

2.5.2 Movimiento de la educación popular......................................... 72

2.6 Trabajadoras, trabajadores y socialismo del siglo XXI como economía de equivalencias

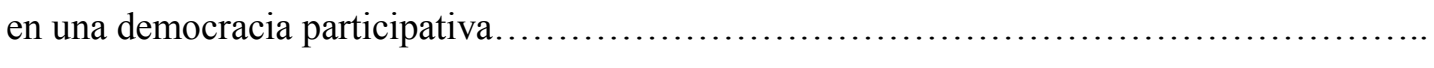


2.7 Socialismo del siglo XXI construido desde abajo en los consejos comunales.............. 78

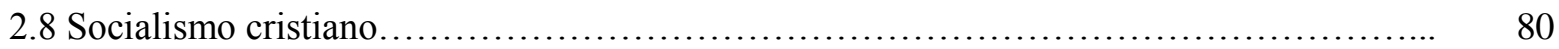

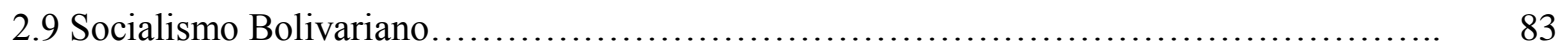

2.10 Socialismo e interculturalidad ................................................ 85

2.11 Socialismo del siglo XXI e integración latinoamericana........................... 88

3 Encuentros teóricos entre el socialismo del joven Marx y el socialismo del siglo XXI......... 91

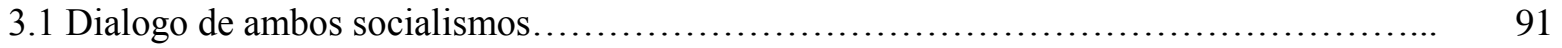

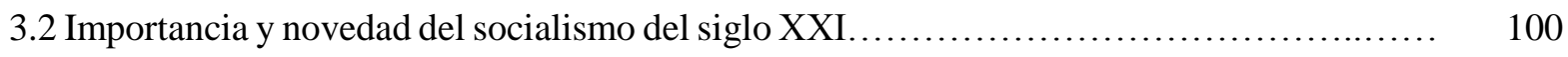

Referencias bibliográficas......................................................... 103 


\section{Introducción}

El socialismo marxista analiza a la historia como la lucha de clases producto del antagonismo de intereses de los dueños de los medios de producción y de los trabajadores. Como forma de establecer un sistema político socialista, propone la llamada dictadura del proletariado, a través de un proceso revolucionario que cambie a la burguesía en el mando y coloque al pueblo obrero en su lugar, con el fin de colectivizar la propiedad de los medios de producción.

La aplicación del socialismo se concretó en la segunda década del siglo XX cuando Lenin toma el poder en Rusia por medio de una lucha armada, agrupando regiones ligadas históricamente y formando la Unión Soviética, país que existió hasta 1991, cuando se disolvió. Este país influyó en el mundo no sólo por el poderío militar sino por su fuerza económica, derivada de la capacidad para extraer las extraordinarias reservas de petróleo, y además de producir rubros agrícolas y pecuarios que le permitían hacer exportaciones, convirtiéndose de esta manera en una potencia mundial. Estas fortalezas le sirvieron para impactar a las naciones vecinas, siendo el polo de referencia internacional del sistema socialista e influenciando a la mayoría de países llamados de la Europa del Este, los cuales adoptaron el comunismo como base de su sistema de gobierno, estatal y económico.

De la misma manera, países como Vietnam del Norte (en la actualidad Republica socialista de Vietnam), Corea del Norte y China, siguieron los pasos de la Unión Soviética, agregándose a los países del sistema socialista. Es importante resaltar que estas naciones todavía son socialistas con sus características propias en el ámbito económico y social. En el caso del continente americano, se habla de Cuba, un país del Caribe que tiene un sistema comunista desde el 01 de enero de 1959. Este país es un centro de difusión de la ideología socialista para toda la América, pero con más influencia en el mundo latinoamericano. 
En Venezuela en el año 2005 el presidente Hugo Chávez hizo la propuesta de construir el socialismo del Siglo XXI con características de la realidad venezolana. Invitaba en ese entonces a construirlo partiendo de las ideas de Carlos Marx, pero no aplicándolas de manera dogmática, sino interpretándolas y releyéndolas desde Venezuela, desde el cristianismo, bolivarianismo, indigenismo, desde las ideas de Robinson (Simón Rodríguez) y desde la participación del pueblo venezolano. También el presidente Chávez decía que el socialismo venezolano pretendía unir todas las corrientes de pensamiento y movimientos populares de lucha por la ecología, participación de la mujer, economía popular, teología de la liberación, movimientos sindicales, clases medias, entre otros más. Citaba a Mariátegui diciendo que el socialismo venezolano no podía ser calco y copia de otros socialismos. ${ }^{1}$

Desde 1999 en América Latina se vienen desarrollando gobiernos de izquierda, que si bien formalmente no hablan de un socialismo del siglo XXI como Venezuela, Ecuador y Bolivia, han apuntado hacia una incorporación de los pueblos, fuente principal del socialismo del siglo XXI. El foro de Sao Paulo en la declaración final de su encuentro del año 2017 describe esta irrupción de la izquierda, de manera autocrítica, en los gobiernos latinoamericanos. Dice este importante y obligado referente foro:

En el primer decenio de elecciones y sucesivas reelecciones de gobiernos de izquierda y progresistas (1999-2009), la necesidad de transformar o reformar la sociedad desde los espacios institucionales recién ocupados, descuidó el desafío de construir hegemonía popular, única fuente de poder capaz de dotarlos de la fuerza necesaria para derrotar los predecibles intentos del imperialismo y las oligarquías criollas de restablecer su antiguo dominio monopólico del Estado, y la vacuna para inmunizarlos contra insuficiencias, desviaciones y errores que provocan desacumulación social y política. En el tiempo transcurrido del segundo decenio de la actual etapa de luchas (2009 hasta hoy) es ese desafío el que dificulta el reconocimiento de la oportunidad para transformar o reformar nuestras sociedades. Donde las fuerzas de izquierda y progresistas perdieron el control del Poder Ejecutivo (Honduras, Paraguay, Argentina y Brasil) los pueblos arrecian la batalla contra la nueva oleada neoliberal, y se reorganizan para

\footnotetext{
${ }^{1}$ Dieterich (citado por Molano Camargo, 2008) interpreta la democracia participativa, que se ha desarrollado en Venezuela con la aprobación de la nueva constitución en el año 1999, como socialismo del siglo XXI. “¿Ha llegado el momento histórico para construir e implementar un nuevo proyecto socialista, es decir, la democracia real participativa?" (p. 141.)
} 
reconquistar los espacios perdidos. Y donde resisten la ofensiva destinada a cerrar los espacios democráticos y revertir las transformaciones sociales, en Venezuela, Bolivia, Ecuador, Uruguay, Nicaragua y El Salvador, nuestras fuerzas siguen trabajando en función de la transformación social por alcanzar su plena y definitiva emancipación, por construir un genuino sistema de integración regional, y por coadyuvar a la construcción de un mundo multipolar en el cual impere una correlación de fuerzas favorable a los pueblos. ${ }^{2}$

Hasta aquí se ha hablado del contexto de este tema. Ahora se pasa a ver el problema. Se comienza diciendo que para desarrollar esta investigación se tiene que primero estudiar a Marx, quien en sus escritos establece una visión emancipadora del ser humano y una antropología emancipadora. Quiere superar esa visión del ser humano obrero como mercancía, explotado por el mismo hombre, para convertirlo en protagonista y artífice de su propia historia. Propone Carlos Marx el llamado socialismo o comunismo.

El socialismo del siglo XXI pretende lo mismo, sueña que el ser humano oprimido (llámese obrera y obrero, campesina y campesino, mujer, indígena, profesional, homosexual, afrodescendiente, etc.) sea protagonista de sus transformaciones al construir la justicia social y la participación de todo ser humano distinto al modelo cultural impuesto por el capitalismo. Quiere superar esa concepción del ser humano consumista esclavo del mercado. Es un nuevo socialismo en perfecta concordancia con la justicia social, con los derechos humanos y la eficiencia económica. Es un humanismo con eficiencia económica, o viceversa, eficiencia económica con humanismo (Guadarrama González, 2012) $^{3}$ Y cuando se habla de eficiencia económica no se dice en el sentido del neoliberalismo puro, sino en apostar por un sistema socialista que procure ganancias económicas que sean redistribuidas en beneficios sociales. Es una eficiencia más allá de la rentabilidad o es una rentabilidad con justicia social. Se le pudiera llamar un socialismo con eficiencia económica ética. Sería un equilibrio entre justicia

\footnotetext{
2 Recuperado de http://forodesaopaulo.org/declaracion-final-del-xxiii-encuentro-del-foro-de-sao-paulomanagua-2017/

3 “En la trayectoria del ideario de orientación socialista desde sus primeras manifestaciones predominó inicialmente, y se ha mantenido en muchas de sus manifestaciones contemporáneas, una mayor preocupación por la lucha de la justicia social y la conquista de derechos para los sectores marginados de la población como intento de conversión del humanismo abstracto en humanismo real, pero, por lo regular, sin atender debidamente el imprescindible desarrollo de la eficiencia económica para cumplir con tales objetivos." (Guadarrama González, 2012, p. 590). Como reza el dicho "primum vivere postea philosophari", "vive primero y luego haz filosofía", es decir la filosofía socialista tiene ayudar a producir bienes y servicios para la justicia social.
} 
social y eficiencia económica y queda abierta la pregunta si este camino conduciría hacia un mundo sin clases sociales. Dice Guadarrama González (2012):

La contradicción fundamental entre el capitalismo real y el socialismo real se ha desempeñado a través del conflicto entre eficiencia económica y justicia social. La experiencia indica que cuando se produce el predominio desproporcionado de uno de estos dos pilares, inmediatamente se afecta el estatus y la estabilidad del otro, porque se producen necesariamente situaciones de crisis que no siempre resultan favorables a los proyectos socialistas. (p. 587-588)

No es un socialismo productivista porque no se puede reducir a la producción cayendo en una economía tipo capitalismo de estado. Borón (2014) hace esta crítica aclarando que el socialismo del siglo XXI no siendo productivista no descuida una producción para el bienestar de todas y todos:

El productivismo en que cayeron gran parte de los experimentos socialistas del siglo xx a la larga terminó socavando las posibilidades de construir una sociedad socialista. Por eso tiene razón Lebowitz cuando afirma que el "socialismo no puede ser el culto por la tecnología. Esta fue una patología para el marxismo, y que se manifestó en la Unión Soviética como minas, fábricas y granjas colectivas inmensas, que supuestamente lograban los beneficios de la economía de escala", pero al precio de burocratizar el proceso de toma de decisiones, desincentivar el protagonismo popular y destruir el medio ambiente. Vale la pena aclarar que la crítica al productivismo no significa desentenderse de la imperiosa necesidad de que una economía socialista sea productiva y eficiente, requisitos indispensables para elevar las condiciones materiales de vida de la población. El productivismo, en cambio, puede ser definido como la ciega e irracional confianza depositada en el desarrollo de las fuerzas productivas, concebidas como capaces de resolver por sí solas todas las necesidades de la nueva sociedad. El deterioro del medio ambiente o el despotismo tecnocrático dentro de la empresa socialista han sido dos de los subproductos más perniciosos del productivismo. Por otra parte, sería un gravísimo error pensar que la productividad y la eficiencia son rasgos que solo definen a una economía capitalista. (p. 244-245)

Hasta aquí se puede decir que, si ambos socialismos buscan la emancipación del ser humano, quiere decir que tienen un fundamento humanista y una visión del ser humano distinta de ser una maquina o producto del mercado; y de un ser humano feliz, así no 
concuerde con el statu quo de la sociedad capitalista: consumista a costa de dejar sin recursos a una gran mayoría.

Así las cosas, se reafirma que el socialismo marxista del Joven Marx es una búsqueda de un humanismo al querer la emancipación de la obrera y obrero, por estar formulado en un ambiente industrial del Siglo XIX. De igual forma, el socialismo del siglo XXI es una búsqueda de un humanismo al querer la emancipación, pero no solo de la obrera y obrero, sino también de la campesina y campesino, profesional de clase media, de todo ser humano constituido en colectivo cultural y de diversidad sexual, por estar propuesto en el ambiente latinoamericano, no solo industrial sino campesino, indígena, de clases medias oprimidas, de diversidad de orientaciones sexuales excluidas, de diversidad cultural. El foro de Sao Paulo, en su declaración final de su encuentro del año 2016 cita estas luchas latinoamericanas, no solo obreras, que pueden ampliar el concepto socialista original:

Es necesario que el Foro de Sao Paulo fortalezca los esfuerzos por la construcciones de un frente político y social continental, integrado por movimientos políticos, sociales y populares de nuestra región, abarcando a amplios sectores de la sociedad, entre ellos aquellos que exigen el respeto a sus derechos personales y colectivo, como por ejemplo, sus orientaciones sexuales en el caso de los grupos LGBT, los sectores de la juventud, las luchas de género por la igualdad de derechos entre hombres y mujeres, los pueblos originarios, los afrodescendientes, que no necesariamente actúan partidariamente, pero que luchan en las calles por sus derechos y el ejercicio de sus expresiones culturales. Todos los partidos de izquierda debemos garantizar espacios en nuestras luchas y en nuestras estructuras a estos sectores. ${ }^{4}$

Al confrontar el humanismo socialista del siglo XXI con el humanismo del Joven Marx surge la pregunta de la similitud de ambos socialismos en su visión del ser humano; por eso cabe la pregunta: ¿Cuál humanismo y visión antropológica del joven Marx están presentes en el socialismo del siglo XXI? Se pregunta su similitud ya que la diferencia es evidente: Marx responde a una realidad europea netamente obrera explotada del siglo XIX, y el socialismo del siglo XXI responde no solo a una realidad obrera sino a todas las realidades

\footnotetext{
${ }^{4}$ Recuperado de http://forodesaopaulo.org/declaracion-final-del-xxii-encuentro-del-foro-de-sao-paulo-san-
} salvador-2016/ 
de discriminación del siglo XXI de latinoamericana, atrás citadas (obrera, obrero, campesina, campesino, mujer discriminada, indígena, profesional, excluido por su orientación sexual, afrodescendiente, etc.).

A partir de esta pregunta sobre la similitud de ambos socialismos se puede captar el objetivo de esta investigación: analizar la antropología filosófica y humanismo del socialismo del siglo XXI, con sus antecedentes en el Joven Marx. Y para lograr este gran objetivo, primero se tiene que analizar la antropología filosófica y humanismo del socialismo del Joven Marx. Luego descubrir la antropología filosófica y humanismo del socialismo del siglo XXI en su realidad latinoamericana indígena, campesina, de movimientos sociales, entre otras más. Y por último investigar la similitud existente entre ambos, y de esta manera establecer la antropología filosófica y humanismo del Joven Marx presentes en el socialismo del siglo XXI.

Más adelante, también a partir de la pregunta de investigación, se quiere reflexionar sobre la importancia de la validez del socialismo XXI como continuación del socialismo del Joven Marx, en cuanto su humanismo y antropología emancipadora. Por lo que todo ser humano que se considera cosa u objeto, debe superar ese estadio de su vida para ser realmente quien es: ser humano y no máquina.

Para avanzar este trabajo de grado vamos a dividirlo en tres capítulos: El primer capítulo se refiere a la antropología y humanismo del socialismo del Joven Marx. El segundo se llama antropología y humanismo del socialismo del siglo XXI. El tercero es un capitulo conclusivo para profundizar la relevancia del nuevo socialismo en el contexto actual y los encuentros teóricos de ambos socialismos. La metodología a utilizar es cotejo de textos, la comparación de textos tanto de Marx como del socialismo del siglo XXI y el método hermenéutico. 
Ahora se va a hablar de la justificación de esta tesis. Esta investigación sobre el socialismo del siglo XXI, se realiza en medio de sus críticas que lo califican con una utopía. El socialismo del siglo XXI es una utopía posible. La utopía es una doctrina o sistema optimista que aparece como irrealizable en el momento de su formulación. Fijémonos que la utopía es una realidad que puede realizarse, por ende, no imposible, a pesar de que al momento de su planteamiento se ve como algo inviable. La utopía al plantearse no está realizada, de lo contrario no sería utopía sino realidad. Algunos, en nombre de sus intereses dicen que la utopía no se realiza. Existe un gran malentendido con esta palabra, porque se cree que utopía es igual a imposible. Así ocurre con el socialismo como utopía. Dicen sus opositores que el socialismo ha traído atraso. Se basan ellos en la experiencia del llamado socialismo real, como el establecido en la extinta Unión Soviética, con su carga negativa, obviando por supuesto sus aportes positivos. Carmen Bohórquez (2012) defiende lo positivo de la experiencia soviética:

Quizás en parte por esta inducida reducción de la experiencia socialista a lo que fue la Unión Soviética y en parte porque las profundas transformaciones políticas que hoy florecen en América Latina tienen sus propias peculiaridades y han tomado cuerpo con el cambio de siglo, se ha dado en llamar a estos nuevos intentos de construir una sociedad centrada sobre la persona humana y no sobre el capital, Socialismo del siglo XXI; denominación que busca subrayar la diferencia con cualquier otra experiencia anterior. Sin embargo, tal calificativo no debe implicar que su novedad o sus particularidades nos autoricen a borrar la historia o a marcar un radical parteaguas con las experiencias socialistas que cubrieron el siglo XX. Pues con todo y los graves errores y desviaciones que se pudieron haber cometido, necesario es subrayar que el Socialismo real que encarnó la Unión Soviética hizo históricamente posible no sólo los otros proyectos socialistas que ya mencionamos, sino también este nuevo socialismo; incluso aunque sólo fuera por el hecho de haber logrado contener durante 70 años la voracidad del imperio. Los desmanes cometidos a partir de entonces por los Estados Unidos y sus aliados sobre el resto del mundo, parecen darnos la razón. (p. 104)

Otros fundamentan su argumento de fracaso socialista en el socialismo cubano, el cual no ha sido derrotado, sino que está desarrollándose. La idea es una cosa y otra es los seres humanos que la realizan. ¿Podemos decir entonces que el cristianismo ha fracasado por la mala actitud de los cristianos? El cristianismo es una teoría, acción y fe, practicada por varios millones de seres humanos. De la misma manera, porque se haya utilizado la idea socialista 
para querer hacer dictadura, como lo fue la Unión Soviética ${ }^{5}$, no quiere decir que no sirva de fundamento para una utopía de equidad social. En el caso cubano podemos decir que, en medio de sus contradicciones, su socialismo ha sido atacado por un bloqueo económico de los Estados Unidos que no le ha permitido avanzar en lo económico. Y son ejemplo que seguir, porque en medio de sus faltas de recursos se han mantenido firmes sin entregarse al dominio extranjero y muestran avances en educación y salud (la misión médica de los cubanos en el mundo ha sido reconocida por la Santa Sede de la Iglesia Católica). Y la misión médica cubana en Venezuela ha sido excelente. Es una medicina humanitaria y gratuita, presente en los Centros de Diagnóstico Integral (CDI).

En Bolivia se relaciona el socialismo del Siglo XXI con el socialismo comunitario. Este socialismo, según García Linera, actual vicepresidente del Estado Plurinacional de Bolivia se basa en las experiencias tradicionales comunitarias de los pueblos originarios presentes en este país que siguen influyendo en gran parte en la vida ética, social y laboral del mismo.

\footnotetext{
5 “No debemos caer en los errores del pasado. Debemos aprender de las experiencias de otros partidos. Miren, aquí, en estos libros, está parte de la historia. Y en éste, de Marta Harnecker; Reconstruyendo la izquierda que recomiendo- vemos qué pasó, con algunas excepciones, con los partidos de izquierda del siglo XX en América Latina. Copiaron el modelo bolchevique de partido. Era lógico que así ocurriera porque el modelo bolchevique de partido tuvo un gran éxito en el nacimiento de la Unión Soviética, en la revolución de octubre de 1917. Como sabemos, ahí había un gran debate entre los bolcheviques y los mencheviques, que dividió al movimiento revolucionario, y al final fue el partido bolchevique de Vladimir llich Lenin el que logró impulsar aquel pueblo a la revolución. Luego, ese partido sufrió una desviación, la desviación stalinista. Lenin no pudo evitarla por que enfermó y murió muy joven; murió a los pocos años del triunfo revolucionario. Y aquel partido se desnaturalizó y terminó siendo un partido antidemocrático. Y aquella maravillosa consigna que decía: "iTodo el poder a los soviets!" terminó transformándose en la realidad en 'Todo el poder para el partido'. Ese es mi modesto criterio. Y eso ocurrió casi al comienzo de la revolución socialista que dio nacimiento a la Unión Soviética. Y vean el resultado 70 años después: cuando cayó la Unión Soviética, ¿qué trabajador salió a defender ese proceso? Y se supone que era el poder de los trabajadores. Y los trabajadores no salieron a defenderlo. Qué cosa tan extraña, ¿no? Ese régimen se convirtió en un régimen elitesco que no pudo construir el socialismo." (Chávez, 2006, Discurso de la unidad). Recuperado de http://www.manuelugarte.org/modulos/biblioteca/c/chavez/chavez.htm
} 
Existen quienes llaman a este socialismo comunitario como teoría del buen vivir de manera simple y unilateral, cuando este aspecto es uno de varios del socialismo comunitario (Katz, 2014). El buen vivir se refiere a vivir en armonía con la naturaleza.

Se ha reflexionado si se puede hacer alguna conexión entre los movimientos originarios y el marxismo. Algunos dogmáticos piensan que no. Otros como García Linera, actual vicepresidente de Bolivia piensa que sí. García Linera dice que la cohesión de los movimientos indígenas se debe al diálogo con los marxistas.

Finalmente, es necesario explicar la importancia de esta investigación. En tiempos en que pareciera que lo único viable para la producción es el libre mercado, con sus presiones a la clase trabajadora y a los movimientos sociales, surge con nuevas fuerzas la idea emancipadora del socialismo esta vez con el nombre de socialismo del siglo XXI. Como dice Marx primero es la realidad y luego la conciencia, constatamos la pobreza de millones de seres humanos en Latinoamérica y esto estimula la conciencia y las ideas de ellos para buscar alternativas distintas al modelo capitalista (alternativas que se traducen en movimientos sociales, feministas, indigenistas, campesinos). Ciertamente que las experiencias socialistas llamadas socialismo real no han sido son perfectas, pero este hecho no justifica la inacción en la búsqueda del progreso y la justicia social del llamado socialismo del siglo XXI. Las ideas marxistas están más vigentes que nunca, las condiciones objetivas están dadas para un cambio histórico. Como dice Dieterich (2017), socialismo del siglo XXI o con otro nombre, es la salida alterna para superar el capitalismo:

Las grandes protestas contra el agotado orden capitalista mundial se dirigen hacia sus tres pilares: la economía crematística de mercado, la democracia plutocrática liberal y el consumismo trivializador. Esta protesta la llaman los medios de comunicación hegemónicos demagógicamente la protesta contra la globalización. La protesta no es contra la globalización, sino contra la plutocracia burguesa que la implementa y se beneficia con ella. En otras palabras, son protestas por una democracia real y una economía solidaria, es decir, una sociedad trans-capitalista. El único paradigma científico existente para esa nueva sociedad es el del 
Socialismo del Siglo 21. Con este nombre u con otro, la especie humana luchara por una nueva sociedad, mejor que la actual. Este anhelo humano, nunca se extinguirá. ${ }^{6}$

${ }^{6}$ Recuperado de http://www.panorama.com.ve/experienciapanorama/Heinz-Dieterich-a-PANORAMAGobierno-y-oposicion-son-igualmente-incapaces-20170112-0001.html 


\section{Antropología y humanismo en el socialismo del joven Marx}

A continuación, se describirá las características de la antropología y humanismo en el socialismo del joven Marx. Para desarrollar este trabajo se comienza por explicar el significado de antropología y el de humanismo. Estos conceptos se explican de manera separada por razones didácticas, ya que son una sola realidad intelectual y práctica. Luego se revisará el concepto del socialismo marxista, para luego finalizar con los aspectos destacados de la antropología y humanismo del mismo, como lo son: el trabajo enajenado, materialismo histórico y la concepción del ser humano.

\subsection{Significado de antropología}

La palabra antropología viene del griego anthropos, es decir, hombre, y logos, tratado. Es la ciencia que se refiere a los fenómenos del ser humano femenino y masculino. Ella estudia al ser humano en su integridad: cultura, historia, costumbres, organización social, economía, evolución, razas. Cuando se dedica a los aspectos sociales se le llama antropología cultural. Cuando estudia la evolución del ser humano y sus variaciones físicas se le llama antropología física. Suardia (2001) dice que esta ciencia tiene un carácter ambivalente: "tiene valor como ciencia natural al referirse su estudio a los aspectos biológicos del hombre, y es ciencia social, puesto que se ocupa de los aspectos culturales y del comportamiento del hombre en el seno de la sociedad" (p. 14). Cuando se unen los aspectos físicos y sociales del ser humano para buscar el sentido último y esencia del mismo, la antropología pasa a ser filosófica. Y ella se pregunta que es el ser humano y para que vive. García Cuadrado (2010) 
dice que la antropología filosófica "es un estudio sistemático del hombre por sus causas últimas y principios esenciales del ser y obrar humanos" (p. 24).

En esta investigación se hablará de la antropología marxista del joven Marx y del socialismo del siglo XXI, esto quiere decir que se estudiará como ambas teorías filosóficas abordan los aspectos antropológicos culturales del ser humano. Este componente social y cultural interesa para este trabajo de grado, y de esta manera analizar la visión del ser humano en el joven Marx y en el socialismo del siglo XXI. En este capítulo, se profundizará la teoría marxista en sus inicios y sus recomendaciones para lograr la revolución obrera como forma novedosa de organización social al servicio de la liberación de los pueblos. Más adelante en el segundo capítulo de este estudio, se hablará de la propuesta socialista del presente siglo como forma de una nueva economía, no solo con los obreros sino con todos los movimientos sociales. Se trata de mirar al ser humano desde el Joven Marx y el socialismo nuevo en sus posturas antropológicas filosóficas, de tal manera que las realidades de los seres humanos puedan trasformar sus ideas de dominación y sometimiento en ideas de construcción de su propio destino. Estas son las propuestas filosóficas para cambiar el mundo ya que la filosofía no es un refugio para alejarse de las injusticias sociales ${ }^{7}$.

\subsection{Significado de humanismo}

El humanismo se refiere a la búsqueda de la dignidad del ser humano. Es una tarea filosófica de situarlo como centro y como fin en sí mismo ${ }^{8}$. Y esta tarea se refiere a la búsqueda de la dignidad humana. Es una ética del ser humano, quien lucha por no ser usado como objeto. Es una preocupación por sus potencialidades. Mirará esta investigación como Marx valora al ser humano al denunciar la injusticia del trabajo enajenado, y la propuesta de una sociedad dirigida por los obreros para que desaparezca la explotación. El humanismo de

\footnotetext{
${ }^{7}$ Como dice Marx (2010) en Ad Feuerbach (11 tesis sobre Feuerbach), tesis número 11: “Los filósofos sólo han interpretado diferentemente el mundo, se trata de cambiarlo o transformarlo". (p. 19)

8 "Kant sostuvo que el hombre no puede ser utilizado como medio para un fin. El hombre es un fin en sí mismo". (Botero Uribe, 2004, p. 204)
} 
Marx es materialista, el cual no es un hedonismo sino una satisfacción de las necesidades materiales del ser humano, es un situar su historia desde la realidad social. Fromm (1978) afirma de este materialismo histórico que:

La interpretación "materialista" o "económica" de la historia no tiene nada que ver con un supuesto impulso "materialista" o "económico" como el impulso fundamental del hombre. Significa que el hombre, el hombre real y total, "los individuos realmente vivos" -no las ideas producidas por estos "individuos"- son el tema de la historia y de la comprensión de sus leyes. La interpretación marxista de la historia podría llamarse una interpretación antropológica de la historia, si se quisiera evitar las ambigüedades de los términos "materialista" y "económico". (p. 24-25)

Más adelante se hablará de este humanismo materialista. También se estudiará, en el capítulo II como el socialismo del siglo XXI quiere construir un humanismo con derechos humanos.

\subsection{Concepto de socialismo marxista}

Al hablar de socialismo es necesario distinguir el socialismo marxista en contraste con los socialismos antes y después de Marx. Han existido socialismos que en nombre de Marx han hecho revoluciones, como el caso de la antigua Unión Soviética, pero que ya no son considerados del Joven Marx.

\subsubsection{Concepto de socialismo en general}

El socialismo realiza el ideal de justicia, es decir la equidad de una sociedad. Socialismo es, por lo tanto, justicia social y justicia social es equidad. Bunge (2010) define de esta manera el ideal socialista: 
Este ideal se justifica tanto ética como científicamente. En efecto, la igualdad social pone en práctica el principio de equidad o justicia; contribuye poderosamente a la cohesión social y es fisiológicamente beneficiosa, como lo sugieren experimentos recientes, que muestran que la exclusión causa estrés, el que a su vez debilita el sistema inmunitario al punto de enfermar... (p. 19)

En consecuencia, la exclusión en una sociedad además de poner a los seres humanos fuera de sus derechos elementales: salud, educación, alimentación, vivienda propia, vestido, etc., los pone en una situación de estrés, quien es un paso a un estado de ansiedad, y de un estado de ansiedad, se está un paso de estado de depresión, la cual determina al desánimo a un ciudadano excluido para luchar por sus derechos. Y un estado de depresión que no se cura, es la muerte total en vida.

Bunge (2010) explica que la igualdad o justicia puede ser entendida literal y calificada, o "meritocrática". Es decir, ser iguales no implica desestimar al que tiene un mérito para ocupar un puesto de responsabilidad. Y el que tiene ese mérito para ocupar ese puesto debe hacerlo sin privilegios y sin privilegiar a nadie por su insignificante capricho. En otras palabras, la igualdad es calificada y meritocrática ${ }^{9}$. Es una igualdad donde se debe trabajar y contribuir con la sociedad o comunidad para superar esa mala visión de un socialismo sin méritos, o un mal llamado socialismo o sistema socialista que fomenta el no trabajar en nombre de una igualdad, para superar así un socialismo populista.

Esta igualdad siempre será en lo económico, de tal manera que, si no se logra, por más que un país, grupo, o partido se llame socialista, y ni siquiera tome acciones que propendan a esta igualdad, no se puede llamar socialista. Bunge (2010) dice acerca de la igualdad económica lo siguiente:

En cualquiera de sus versiones, el igualitarismo implica la igualdad económica y, a su vez, ésta implica una limitación drástica de la propiedad privada de los

\footnotetext{
9 “El socialismo meritocrático practica la divisa propuesta por Louis Blanc en 1839: 'A cada cual, conforme a sus necesidades, y de cada cual según sus capacidades'. Blanc llamó 'proporcionalidad' a esta forma de igualitarismo calificado o meritocrático. Esa fórmula se complementa con la divisa de la Primera Internacional Socialista: "Ni deberes sin derechos, ni derechos sin deberes". (Bunge, 2010, p. 19.)
} 
medios de producción, intercambio y financiación. En otras palabras, el socialismo incluye la socialización de dichos medios. (p. 19)

\subsubsection{Socialismo Marxista}

La teoría de Marx se le llama socialista por buscar la equidad en la vida social y no solo en la esfera económica sino también en el espiritual que abarca lo cultural.

Para encontrar el verdadero socialismo marxista es necesario adentrarse en sus escritos y sobre todo en sus manuscritos de 1844, que fueron publicados por primera vez, y por ende descubiertos, a principios del siglo XX, en 1932. Marcuse (1971), dice que este descubrimiento causo un revuelo en la visión que se tenía de Marx:

La publicación de los Manuscritos económicos-filosóficos de Marx, escritos en 1844, debe convertirse en un acontecimiento determinante en la historia de la investigación marxista. Estos manuscritos podrían ofrecer una nueva base para la discusión en torno al origen del materialismo histórico y para toda la teoría del "socialismo científico; permiten además un enfoque más fecundo y más rico en perspectivas acerca de las relaciones exactas entre Marx y Hegel. (p. 9)

Antes de la publicación de estos manuscritos, algunos de sus críticos y opositores tenían la idea de que Marx solo era un economista y no un filósofo, por lo menos a final de su vida. A partir de este descubrimiento se termina de entender el materialismo histórico como visión del mundo a partir de las realidades concretas del ser humano, especialmente del ser humano obrero en dialogo con la industria que lo explotaba. Es una dialéctica materialista. En este dialogo de las realidades materiales del obrero surge la idea y praxis revolucionaria.

En los manuscritos, Marx fundamenta su socialismo con base a una interpretación filosófica del ser humano, no como mercancía, como lo concibe el capitalismo, sino como actor de una nueva historia emancipada. Marx (2013) explica filosóficamente la explotación del obrero partiendo de la realidad para llegar a la idea o teoría: "La enajenación del trabajador en su objeto se expresa, según las leyes económicas, de la siguiente forma: cuanto más produce el trabajador, tanto menos ha de consumir, cuantos más valores crea, tanto más sin 
valor, tanto más indigno es él" (p. 137). Esta es la realidad del obrero, es enajenado de lo que produce, solo trabaja para subsistir, y no para disfrutar del producto de su trabajo. Esta enajenación solo es superada por el comunismo, que es lo mismo que socialismo marxista:

El comunismo como superación de la propiedad privada en cuanto autoextrañamiento del hombre, y por ello como apropiación real de la esencia humana por y para el hombre; por ello como retorno del hombre para sí en cuanto hombre social, es decir humano; retorno pleno, consciente y efectuado dentro de toda la riqueza de la evolución humana hasta el presente. Este comunismo es, como completo naturalismo $=$ humanismo, como completo humanismo $=$ naturalismo; es la verdadera solución del conflicto entre el hombre y naturaleza, entre el hombre y el hombre, la solución definitiva del litigio entre existencia y esencia, entre objetivación y autoafirmación, entre libertad y necesidad, entre individuo y género... (Marx, 2013, p. 173-174).

El comunismo, como teoría y praxis revolucionaria es producto de la dialéctica entre la clase burguesa, dueña de la propiedad, y la clase proletaria expropiada de la mercancía producida por ella misma. Marx aplica filosóficamente el método dialectico de Hegel a la realidad histórica. Va a superar la dialéctica idealista para fundar la dialéctica materialista. Con esta superación de Hegel, podemos ver la relación que tenía Marx con él y así aclarar la idea de que Marx estaba alejado de Hegel. Y esta aclaración también se debe a la salida a la luz de los Manuscritos. De la relación de Marx con Hegel, dice Marcuse (1971): “...La gran importancia de los nuevos manuscritos se debe al hecho de que son el primer documento en el cual se expone claramente la polémica de Marx respecto a la Fenomenología del espíritu de Hegel...” (p. 10). Y Marx (2013) dirá en estos manuscritos que la Fenomenología del espíritu de Hegel, es la “...fuente verdadera y secreto de la filosofía hegeliana” (p. 226). Entonces, si conocía muy bien a Hegel.

Para la burguesía, la dialéctica estaba cerrada o completada con el estado burgués. Con la dialéctica idealista quería superar las contradicciones entre proletariado y burguesía, 
aplicando el método de Hegel de reconciliar la realidad con el concepto ${ }^{10}$. Pretendían resolver el problema de la pobreza proletaria con solo ideas, para así resolverlo solo en la mente con su propuesta de estado burgués, como concepto absoluto reconciliado falsamente con la realidad obrera. Pero con la dialéctica de Marx se avanza, como hemos dicho, desde la realidad hasta llegar a la idea. Korsh (1978) dice de la dialéctica de Marx lo siguiente:

...la esencia de la nueva "dialéctica materialista" de la clase proletaria consistirá precisamente en eliminar de hecho la contradicción material entre la riqueza burguesa (el "capital") y la miseria proletaria, mediante la abolición de esta sociedad de clases burguesa y de un Estado burgués clasista en la realidad de la sociedad comunista sin clases... (p. 177)

Marx, de forma genial, pondrá a dialogar la clase burguesa con sus antítesis, la clase proletaria, para llegar a la idea y praxis conjunta de la sociedad comunista, pero no como un fin cerrado, sino siempre dialécticamente abierto a la revolución, como proceso nunca terminado sino dinámico. Por este motivo se puede hablar de revolución dentro de la revolución.

En los manuscritos de 1844 se habla del ser humano como ser social, sin renunciar a la individualidad. Entonces, el socialismo marxista no es un colectivismo donde se niega a reconocer la dignidad y libertad de cada quien (la Unión Soviética impuso su marxismoleninismo diferente del marxismo del Joven Marx, por lo tanto, es cuestionable ese método); sino que las circunstancias históricas conllevan a la revolución, para que esta valore la dignidad de cada ser humano por separado, pero haciéndole entender, que cada persona o individuo es un ser social, porque cada uno es sociedad así este solo; así alguien viva solo en una zona inhóspita, es un ser social porque depende de otros, y porque lo que haga y deje de hacer influye en los otros. Fromm (1962) explica que para Marx “...cada individuo representaba a la sociedad, es decir, a la humanidad como un todo, la universalidad del

10 “...si a Hegel le interesaba la reconciliación del concepto con la realidad, lo cual solo se da con el saber absoluto, a Marx le interesa algo más que eso. Como ha dicho Umberto Cerroni: 'explicar el mundo para él no basta', por eso era necesario pasar a la praxis, a la revolución...”. (Pachón Soto, 2013, p. 33) 
hombre..." (p. 60). Por lo tanto, socialismo no es una abstracción para dominar. Marx (2013), explica como lo social no está reñido con lo individual:

...El individuo es el ser social. Su exteriorización vital (aunque no aparezca en la forma inmediata de una exteriorización vital comunitaria, cumplida en unión de otros) es así una exteriorización de la vida social. La vida individual y la vida genérica del hombre no son distintas, por más que, necesariamente, el modo de existencia de la vida individual sea un modo más particular o más general de la vida genérica, o sea la vida genérica una vida individual más particular o general. (p. 177)

Por lo tanto, socialismo no es una abstracción, es una concreción porque el ser humano por razones prácticas necesita del otro, y todo lo que realiza influye en los otros. Y el ser individual y particular es el sujeto de la sociedad:

El hombre así, por más que sea un individuo particular (y justamente es su particularidad la que hace de él un individuo y un ser social individual real), es, en la misma medida, la totalidad, la totalidad ideal, la existencia subjetiva de la sociedad pensada y sentida para sí, del mismo modo que también en la realidad existe como intuición y goce de la existencia social y como una totalidad de exteriorización vital humana. (Marx, 2013, p. 178)

En el manifiesto comunista, otro escrito de Marx, pero acompañado de Engels, se desarrolla también el pensamiento socialista del Joven Marx. En este manifiesto se confirma la teoría materialista de la historia con su dialéctica. Por este motivo, Marx y Engels dicen que las condiciones políticas y sociales a partir de la revolución burguesa o revolución industrial ocurrida a partir del siglo XVIII en Europa, van a generar la revolución proletaria. En el punto donde describen la actitud de los comunistas ante los diferentes partidos de oposición, indican la posición del partido comunista alemán, quienes conocen muy bien la teoría revolucionaria. Esto es lo que escriben en el manifiesto comunista:

Pero jamás en ningún momento, se olvida este partido de inculcar a los obreros la más clara conciencia del antagonismo hostil que existe entre la burguesía y el proletariado, a fin de que los obreros alemanes sepan convertir de inmediato las condiciones sociales y políticas que forzosamente ha de traer consigo la dominación burguesa en otras tantas armas contra la burguesía, a fin de que tan 
pronto sean derrocadas las clases reaccionarias en Alemania, comience inmediatamente la lucha contra la misma burguesía. (Marx y Engels, 2007, p. 48).

Como las ideas siempre han estado unidas a las condiciones de vida, entonces las condiciones que surgen a partir de la revolución burguesa van a producir la idea de la revolución proletaria. El manifiesto dice de la relación de la idea con la realidad:

\begin{abstract}
¿Acaso se necesita una gran perspicacia para comprender que con toda modificación en las condiciones de vida, en las relaciones sociales, en la existencia social, cambian también las ideas, las nociones y las concepciones, en una palabra, la conciencia del hombre? (Marx y Engels, 2007, p. 31)
\end{abstract}

Fromm (1962) va a explicar muy bien lo dicho por Marx que primero es la realidad y luego la conciencia, y esto es el materialismo histórico, pero en el sentido de que la realidad mueve al ser humano a buscar su liberación y a no a ser esclavo de lo material como desviadamente interpretan a Marx: “ “...en realidad, el materialismo histórico no es en absoluto una teoría psicológica; sostiene que el modo de producción del hombre determina su pensamiento y sus deseos y no que sus principales deseos sean la de obtener la máxima ganancia material..." (p. 23-24). Y de la realidad de pobreza del trabajador por producir en condiciones infrahumanas, va a surgir, por su propia reflexión, una conciencia de clase capaz de mirar las contradicciones con la burguesía. Y de los deseos e ideas de máxima ganancia del burgués dueño de los medios de producción, determinados por el modo de producción, surge su deseo de explotación y su visión del trabajador como cosa y no como humano, producto de su ganancia fácil.

La prevalencia de la realidad social sobre la conciencia no quiere significar para Marx y Engels (2007) una renuncia a la fuerza de las ideas, quien afirma: “...Las ideas dominantes en cualquier época no han sido nunca más que las ideas de la clase dominante” (p. 31). Es tal la fuerza de la idea que siempre se han conseguido en la historia del capitalismo obreros con mentalidad burguesa. Por este motivo, cuando existen estas ideas falsas el papel de la filosofía es construir ideas a partir de la realidad social y en el caso de los obreros construir una idea y deseos que puede hacerlos superar su explotación y así ser liberados. También es necesario 
líderes que promuevan el cambio material para que se dé paralelamente el cambio de conciencia. Fromm (1962) explica lo que piensa Marx de las ideas falsas:

En primer lugar, hay que advertir que Marx, como Spinoza y más tarde Freud, creía que la mayor parte de lo que los hombres piensan conscientemente es conciencia "falsa", ideología y racionalización; que las verdaderas fuentes de los actos del hombre son inconscientes. [...] según Marx, se originan en toda la organización del hombre, que dirige su conciencia en determinadas direcciones y le impide que cobre conciencia de determinados hechos y experiencias. (p. 32)

Por lo tanto, Marx, quería reconciliar la idea con la realidad como se ha afirmado, pero a partir de la realidad social emancipada. Toda esta relación de la idea, de la conciencia con la realidad produce el comunismo o la revolución proletaria a partir de la coincidencia de circunstancias con la conciencia: "La coincidencia del cambio de las circunstancias y de la actividad humana o cambio o transformación de sí mismo solo puede concebida y comprendida racionalmente como praxis revolucionaria” (Marx 2010, p. 15, tesis número 3 sobre Feuerbach). La actividad humana o cambio de los hombres no es más que la realidad, es decir la conciencia, en otras palabras, la realidad social.

Marx (2010) dice, en la segunda tesis sobre Feuerbach, que verdad y practica deben corresponder: "En la praxis tiene el ser humano que comprobar la verdad, es decir, la realidad efectiva y el poder, la terrenidad, de su pensamiento" (p. 14). Para Marx la idea comunista coincide con la práctica comunista, ya que esta práctica es social. Lo que quiere decir que toda idea debe realizarse en la práctica y que idea de la burguesía es idealista porque no se realiza en la práctica social, sino en un reducido mínimo de personas y en la mente de millones, pero como idea y no como práctica. ${ }^{11}$

\footnotetext{
${ }^{11}$ La octava tesis sobre Feuerbach de Marx (2010) dice: "Toda vida social es esencialmente práctica. Todos los misterios que inducen a la teoría al misticismo encuentran su solución racional en la praxis humana y en la compresión de esta praxis" (p. 18). La novena tesis sobre Feuerbach de Marx (2010) dice lo siguiente: "A lo máximo que llega el materialismo contemplativo o intuitivo, es decir, el materialismo que no concibe la sensibilidad o lo sensible como actividad práctica, es a la contemplación o intuición de los individuos singulares y de la sociedad civil-burguesa" (p. 18). El materialismo de Feuerbach es idealista, no critica la burguesía, sino que la mira como algo sensible para contemplar y no para transformarla o para que desaparezca. $Y$ ve los individuos como singulares, existentes en lo concreto, pero de manera aislada y no social.
} 
Hasta aquí hemos explicado cómo se llega al socialismo comunista o marxista. Ahora vamos explicar que significa. El comunismo para Marx es la superación del trabajo enajenado (más adelante hablaremos del tema). Fromm (1962) dice que el fin del socialismo marxista o comunismo es el hombre:

...Es crear una forma de producción y una organización de la sociedad en que el hombre pueda superar la enajenación de su producto, de su trabajo, de sus semejantes, de sí mismo y de la naturaleza; en que pueda volver a sí mismo y captar el mundo con sus propias facultades, haciéndose uno, así con el mundo... (p. 69)

Es la apropiación de los medios de producción por parte de los proletarios. El manifiesto comunista establece que el comunismo se empieza con un periodo de derrocamiento violento del proletariado para luego dar paso a un gobierno de ellos, que siempre se ha interpretado como una dictadura, pero que a la larga será una democracia, ya que el mismo Marx y Engels (2007) habla de tomar la democracia: “...el primer paso de la revolución obrera es la elevación del proletariado a clase dominante, la conquista de la democracia” (p. 33). Este dominio de la clase proletaria se concreta en su organización como estado para expropiar la propiedad privada, uso de la renta de la tierra, nacionalizar los bancos en uno solo, centralización de los medios de transportes, impulso de creación de fábricas, empleos de las tierras, obligación de trabajar para todos por igual, desaparición de la diferencia entre ciudad y campo con la integración de industria y agricultura, educación pública gratuita para niños y eliminación del trabajo de ellos, educación para producir y con producción material. Todas estas medidas las tomaría la clase obrera con vistas a crear una sociedad sin clases en contradicción. Igualmente seguiría la dialéctica materialista por las contradicciones que surgirán en esa clase única.

La propiedad privada es superada en el comunismo primero por la propiedad general. Marx (2013) plantea que el comunismo surge de la contradicción entre trabajo y capital, porque "La esencia subjetiva de la propiedad privada, la propiedad privada como actividad 
para sí, como sujeto, como persona, es el trabajo...” (p. 163), y “...el capital, el trabajo objetivo como exclusión del trabajo..." (p. 169), o el capital como objetivación del trabajo. Se produce aquí una exclusión del trabajador, sujeto de la propiedad privada, del capital (en teoría serian lo mismo propiedad privada y capital, y estos, resultados del trabajo del obrero) y por tanto la oposición trabajo-capital. Sujeto de la propiedad privada porque es quien trabaja para que otro se apropie del producto de su trabajo, y, por lo tanto, con derecho a ser dueño de la propiedad privada, ya que no posee nada y es negado como ser humano, por la citada contradicción entre trabajo y capital. Sujeto de la propiedad privada porque ella es capital extrañado al trabajador o extrañamiento del fruto del trabajo del obrero ${ }^{12}$. Entonces el comunismo al convertir la propiedad privada en propiedad general es síntesis de esta contradicción: “...El comunismo, finalmente, es la expresión positiva de la propiedad privada superada; es, en primer lugar, la propiedad privada general...” (Marx, 2013, p. 170). Quiere decir que esta primera superación es un avance que Marx llama comunismo "grosero e irreflexivo" porque es llevar el deseo de propiedad desordenado o codicia y la propiedad real a toda la comunidad de hombres y mujeres. Este comunismo "grosero e irreflexivo" es una crítica de Marx al mismo para luego poder llegar al comunismo verdadero defendido por él: “...El comunismo grosero no es más que el remate de esta codicia y de esta nivelación a partir del mínimo representado..." (Marx, 2013, p. 171). Primero es una nivelación fruto de la codicia ("comunismo grosero e irreflexivo") y luego una nivelación fruto de la comunidad humana (comunismo del joven Marx).

El comunismo es igual a decir comunidad o vida en comunidad. Una comunidad que se apropia de las cosas para que tengan todos por igual. Pero como se dijo con Marx, primero se establece un comunismo "grosero e irreflexivo" para pasar a un comunismo o "comunidad positiva", que hace ver al ser humano en una relación humana con la naturaleza y con sus semejantes desde la necesidad verdadera ${ }^{13}$ y no de necesidades creadas y falsas del ser

\footnotetext{
12 “La relación de la propiedad es trabajo, capital y relación entre ambos” (Marx, 2013, p. 161).

13 Según Leopold (2012), Marx incorpora y amplía las necesidades verdaderas para vivir (necesidades no volitivas básicas) en necesidades sociales menos básicas: "De los primeros escritos se puede extraer una lista razonablemente amplia de necesidades sociales menos básicas. El joven Marx alude a la necesidad humana de esparcimiento (salir 'a tomar algo', a 'bailar', a 'practicar esgrima', a 'cantar'), a la necesidad de cultura ('ir al teatro'), de educación y ejercicio intelectual ('pensar', 'teorizar', 'comprar libros', 'aprender'), de expresarse
} 
humano, aunque individual, pero con un sentido colectivo. Fromm (1962) dice que para comprender el comunismo hace falta distinguir entre necesidades verdaderas y artificiales, para de esta manera, fundar una sociedad al servicio del ser humano y no del capital, ya que este último solo busca reproducirse a costa de falsas necesidades: “...Solo podrá entenderse la concepción del socialismo de Marx si se comprende la distinción que hace Marx entre verdaderas necesidades del hombre y las necesidades sintéticas, artificialmente producidas" (p. 72).

El comunismo se puede entender desde el objeto como realización de la individualidad del ser humano, para sí mismo y para el otro. Y desde el objeto apropiado por el ser humano individual y social se comprende mejor el comunismo. Y a partir de tener claridad del hombre como ser social se concluye en el comunismo. Marx dice que a partir del material de trabajo y del hombre como sujeto y punto de partida se deduce la necesidad histórica de la propiedad privada, y luego el surgimiento del comunismo como síntesis de la contradicción entre la propiedad privada y la enajenación de la misma. Y en este movimiento histórico de la propiedad privada surge el comunismo.

Anteriormente se dijo que el primer comunismo es "grosero e irreflexivo" por qué solo desea poseer por poseer, de manera egoísta y codiciosa, por este motivo, Marx (2013) plantea filosóficamente el comunismo como apropiación social de la propiedad privada de tal manera que no solo el ser humano desee poseer, sino que vea que todas sus facultades son sociales y no egoístas:

artísticamente ('pintar'), de realizarse emocionalmente ('amar'), y de gozar placer estético (Marx sostiene que 'el oído musical, la percepción de las belleza de las formas' es una de las capacidades y de las facultades humanas esenciales)" (p. 248). Marx (2013) de forma irónica habla de estas necesidades espirituales al hacer la crítica a la economía política: ... “la Economía, pese a su mundana y placentera apariencia, es una verdadera ciencia moral, la más moral de las ciencias. La autorenuncia, la renuncia a la vida y a toda humana necesidad es su dogma fundamental. Cuanto menos comas y bebas, cuanto menos licores compres, cuanto menos vayas al teatro, al baile, a la taberna, cuanto menos pienses, ames, teorices, cantes, pintes, esgrimas, etc., tanto más ahorras, tanto mayor se hace tu tesoro al que ni polillas ni herrumbre devoran, tu capital. Cuanto menos eres, cuanto menos exteriorizas tu vida, tanto más tienes, tanto es mayor tu vida enajenada y tanto más almacenas de tu esencia..." (p. 194). 
...Cada una de sus relaciones humanas con el mundo (ver, oír, gustar, sentir, pensar, observar, percibir, desear, actuar, amar), en resumen, todos los órganos de su individualidad, como los órganos que son inmediatamente comunitarios en su forma, son, en su comportamiento objetivo, en su comportamiento hacia el objeto, la apropiación de éste. La apropiación de la realidad humana, su comportamiento hacia el objeto, es la afirmación de la realidad humana... (p. 179).

La filosofía de Marx es la filosofía de la apropiación del objeto como superación de la propiedad privada. Si el ser humano, concebido este como ser colectivo, se apropia de los objetos no solo por tenerlo de manera egoísta, sino por disfrutarlos para vivir, entonces este el verdadero comunismo ya no irreflexivo y grosero. Con el comunismo “... Necesidad y goce han perdido su naturaleza egoísta y la naturaleza ha perdido su pura utilidad, al convertirse la utilidad en utilidad humana" (Marx, 2013, p. 180).

El comunismo establece una relación con los objetos de manera humana, es un oír, ver, gustar, tocar y un oler de manera humana. Es un relacionarse por buscar conectarse con el objeto para obtener un fin humano, es decir que beneficie al ser humano. Es encontrar el sentido del objeto, ponerse frente a él de manera crítica, de no pasarlo completo sin antes analizarlo, de no oír por oír o comer por comer. Y en esa relación critica cada individuo se dará cuenta que ese objeto no es solo suyo, es para todo aquel que lo necesite. Entonces, el objeto será social porque es humano, y porque este último es social. En otras palabras, el objeto al hacerse humano se hace social, y, por lo tanto, se puede superar la propiedad privada de los objetos. Y a través de los objetos debidamente humanizados, el ser humano se hace social y viceversa, el ser humano social convierte a los objetos en propiedad social o comunismo. Marx (2013) explicará muy bien esta idea diciendo:

...únicamente cuando el objeto es para el hombre objeto humano u hombre objetivo deja de perderse el hombre en su objeto. Esto sólo es posible cuando el objeto se convierte para él en objeto social y él mismo se convierte en ser social y la sociedad, a través de este objeto, se convierte para él en ser. (p. 180-181) 


\section{$1.4 \quad$ Trabajo enajenado}

El trabajo es una categoría filosófica por ser algo exterior y realización del ser humano. Es una definición ontológica en Marx (en Marcuse, 1971), quien afirma: “ ‘...El trabajo es el devenir -para sí- del hombre, dentro de la alienación o como hombre alienado'; es la 'autocreación o el acto de auto-objetivación por parte del hombre...'” (p. 22).

En el trabajo el hombre se autocrea, es decir, en su trabajo se convierte en lo que es como hombre. En el trabajo el hombre existe para sí, es una actividad libre distinta al del ser animal, por lo que se coloca frente al trabajo como ser distinto. En el trabajo se realiza el ser humano.

Marx busca la base del trabajo, que la Economía Política de su tiempo veía como natural, sin cuestionamientos. No explica la Economía Política las injusticias, las ve como producto necesario, como parte natural de la historia; describe como un hecho normal la explotación del hombre. ${ }^{14}$ La economía nacional burguesa es una justificación del capitalismo, que no ve la "...separación del hombre respecto al trabajo, el capital y la tierra..." (Marx en Marcuse, 1971, p. 12). No ve esta economía el enfrentamiento al que se somete el hombre a su objeto de trabajo y vendiéndose este último como mercancía.

Y buscando esa base, Marx, creará un concepto interesante llamado trabajo enajenado. Es una crítica al trabajo explotado del obrero en las fábricas de su época, quienes trabajaban de 12 a 16 horas diarias ${ }^{15}$ y era considerado una mercancía. Así lo afirman Marx y Engels (2007):

\footnotetext{
${ }^{14}$ Los manuscritos de Marx de 1844 tratan "...de una crítica y de una fundación filosóficas de la economía nacional en el sentido de una teoría de la revolución." (Marcuse, 1971, p. 9.)

15 "...hay que tomar en cuenta la jornada de trabajo habitual antes y ahora. Esta ha sido elevada para los obreros ingleses en la manufactura algodonera, desde hace 25 años, esto es, exactamente desde el momento en que se introdujeron de las máquinas para ahorrar trabajo, a doce o dieciséis horas diarias, y elevación en un país y una rama de la industria tuvo que extenderse más o menos a otras partes, dado el derecho, aun generalmente reconocido, a una explotación incondicionada de los pobres por los ricos" (Shulz, Bewegung der Produktion. En: Marx, 2013, p. 77).
} 
En la misma proporción en que se desarrolla la burguesía, es decir, el capital, desarróllese también el proletariado, la clase de los obreros modernos, que no viven sino a condición de encontrar trabajo, y lo encuentran únicamente mientras su trabajo acrecienta el capital. Estos obreros, obligados a venderse al detal, son una mercancía como cualquier otro artículo de comercio, sujeta, por tanto, a todas las vicisitudes de la competencia, a todas las fluctuaciones del mercado. (p. 16.)

Marx hizo una filosofía para superar a Hegel. La teoría de Marx tiene un fundamento filosófico que la convierte en una teoría de la práctica y de la revolución, de la caída del capitalismo provocada por el proletariado en su lucha económica y política:

...Esto es precisamente lo que se debe ver y entender, es decir: que la economía y la política se han convertido, en virtud de una interpretación filosófica bien definida del ser humano y de su realización histórica, en la base económicapolítica de la teoría de la revolución. (Marcuse, 1971, p. 11)

Hegel formuló su explicación de la realidad con el concepto, pero Marx le interesaba ir más allá, es decir trasformar la realidad con la revolución. Dice Marcuse que la crítica de Marx a Hegel no es su método dialectico filosófico, sino el contenido mismo filosófico hegeliano.

La relación de Marx con Hegel se encuentra en los manuscritos. Son una crítica a la economía de la nación de Marx (Alemania):

...ya que las categorías fundamentales de la teoría de Marx surgen aquí de la diferencia categórica con la filosofía hegeliana (por ejemplo, en lo que se refiere al trabajo, la objetivación, la enajenación, la absorción y la propiedad); o sea que Marx no ha adoptado el "método" modificado de Hegel para darle vida después de insertarlo en nuevo contexto, sino que, volviéndose hacia la misma base -la cual fundamenta el método- de la filosofía hegeliana, se apropia de su verdadero contenido y lo amplía. La gran importancia de los nuevos manuscritos se debe al hecho de que son el primer documento en el cual se expone claramente la polémica de Marx respecto a la Fenomenología del espíritu de Hegel, "verdadero lugar de origen y clave de la filosofía hegeliana". (Marcuse, 1971, 2013, p. 10.)

Hegel en su fenomenología dice que la esencia del hombre es la conciencia de sí. Entonces esta conciencia es pensamiento, es intelecto; es abstracta. El objeto para Hegel es la negatividad de la conciencia; y este existe en la medida que le es devuelto. Fromm (1962) dice de Hegel: $\quad$ “... es el problema de la relación entre la esencia y existencia. En el 
proceso de la existencia, se realiza la esencia y, al mismo tiempo, existir significa una vuelta a la esencia..." (p. 38). Esto quiere decir que, para Hegel, si el hombre es solo pensamiento, entonces su realidad material no es importante.

Marx (en Marcuse, 1971) explicando a Hegel dice que la objetividad del hombre está en la conciencia:

Lo esencial es que el objeto de la conciencia no es otra cosa que la conciencia, o también que el objeto no es sino la conciencia objetivada, la conciencia como objeto (...) Por lo tanto, se trata de dominar el objeto de la conciencia. Entendida de esta manera la objetividad es válida para una relación del hombre, alienada, inadecuada y no conforme con el ser humano (...) (p. 63)

Esta es una valiosa crítica de Marx a Hegel, quien observa que la objetividad del hombre está en la relación humana con el objeto. Marcuse (1971) dice que Marx define esta objetividad como:

...la relación humana sin la cual el hombre no puede llegar a la auto-realización y afirmación; era, pues, la "verdadera" objetividad, la "obra" del trabajo humano $\mathrm{y}$, en ningún caso, el objeto de la conciencia abstracta. Ya que defiende semejante punto de vista, Marx puede decir que Hegel hace del hombre "un ser no-objetivo y espiritual"; este ser que nunca se encuentra a sí mismo en los verdaderos objetos sino siempre y únicamente en la negatividad de sí mismo, que tampoco se encuentra en su "ser-otro como tal"; ese ser se vuelve finalmente un ser "inobjetivo" y "un ser inobjetivo es un no-ser" (p. 63-64).

La realidad del hombre sería entonces, para Hegel, un objeto abstracto. Sería una realidad dominada por la conciencia y no por lo material, de tal manera que esa conciencia sería una causa de alienación del hombre quien tendría que ver su dominación por el trabajo como algo anejo a él. A continuación se explicará el trabajo enajenado como un extrañamiento a su objeto de trabajo, es decir como el fruto del trabajo del hombre se le hace extraño por no poder beneficiarse de él.

Se ha dicho anteriormente que los Manuscritos de 1844 de Marx son la fundación de una teoría revolucionaria. Son un análisis filosófico de la economía y del trabajo para luego 
hacer una praxis de dicha filosofía, es decir, para lograr la liberación del hombre de este trabajo enajenado.

En el primer manuscrito de Marx se explica que la miseria del obrero es todo lo contrario a la abundancia de la producción. Esto lo justifica la economía política cuestionada por Marx, la cual no ve la pobreza como una consecuencia natural del capitalismo. No explica la economía política las injusticias, las ve como parte casual de la historia y no como producto necesario dialectico. También observa que la explotación del obrero es un hecho normal.

Marx plantea dos tipos de trabajo: un trabajo que realiza al ser humano y lo que hace feliz ${ }^{16}$, y un trabajo enajenado que lo convierte en mercancía ${ }^{17}$ y lo hace infeliz. Un trabajo que puede ser armonioso con la naturaleza u otro que puede ser hostil con ella. Explica Fromm (1962) lo que significa el trabajo para Marx:

...El trabajo es el factor que constituye la mediación entre el hombre y la naturaleza [...] El trabajo es la expresión de la vida humana y a través del trabajo se modifica la relación del hombre con la naturaleza; de ahí que mediante el trabajo se modifique a si mismo... (p. 28)

Se modifica para su bien o para su mal con el trabajo.

El trabajo enajenado no realiza el ser del hombre porque no se autocrea, ni se realiza como tal. Marcuse (1971) comentando a Marx, quien reflexiona el concepto de trabajo enajenado, dirá: “...El trabajo ya no es 'libre actividad' y tampoco es universal y libre auto-

\footnotetext{
16 “Casi todo el mundo está de acuerdo, con razón, en que el joven Marx pensaba que la realización a través del trabajo es un elemento central del desarrollo humano. Por supuesto que no todos los trabajos reúnen las condiciones adecuadas para la realización. De hecho, Marx afirma que la actividad productiva más característica del mundo social moderno crea 'monstruos atrofiados' en lugar de seres humanos plenos..." (Leopold, 2012, p 248). Marx (2013) habla de los dos tipos de trabajo: "Ciertamente el trabajo produce maravillas para los ricos, pero produce privaciones para el trabajador. Produce palacios, pero para el trabajador chozas. Produce belleza, pero deformidades para el trabajador. Sustituye el trabajo por maquinas, pero arroja una parte de los trabajadores a un trabajo bárbaro, y convierte en máquinas a la otra parte. Produce espíritu, pero origina estupidez y cretinismo para el trabajador" (137-138).

17 "El obrero es más pobre cuanta más riqueza produce, cuanto más crece su producción en potencia y volumen. El trabajador se convierte en una mercancía tanto más barata cuantas más mercancías produce. La desvalorización del mundo humano crece en razón directa de la valorización del mundo de las cosas. El trabajo no sólo produce mercancías; se produce también a sí mismo y al obrero como mercancía, y justamente en la proporción en que produce mercancías en general" (Marx, 2013, p. 134).
} 
afirmación del hombre en la totalidad de su exteriorización vital sino un 'no-ser', un sujeto meramente físico en una actividad 'abstracta'..." (p. 41). Es una actividad que es pensamiento objetivado, y, por lo tanto, ajena totalmente a su ser. Y es una actividad que produce mercancías ajenas y distantes de su realidad. Mercancías que el ser humano no puede aprovechar para realizarse y para ser feliz. Dice Marcuse (1971) que estas mercancías son “...cosas extrañas que ningún modo pertenecen al trabajador...” (p. 41-42). Y con un trabajo enajenado la existencia del hombre no es un "sí mismo" para su autoafirmación, sino un medio para su solo existir físico. El trabajador enajenado se convierte en un animal solamente subsistiendo y no viviendo en su integridad con la naturaleza, con las cosas que produce con su trabajo. Marx (2013) dice que el trabajo enajenado no es del trabajador, es ajeno a él, aunque es realizado por él:

...para el trabajador se muestra la exterioridad del trabajo en que este no es suyo, sino de otro, que no le pertenece; en que cuando está en él no se pertenece a sí mismo, sino a otro [...] De esto resulta que el hombre (el trabajador) sólo se siente libre en sus funciones animales, en el comer, beber, engendrar, y todo lo más en aquello que toca a la habitación y al atavío, y en cambio en sus funciones humanas se siente como animal. Lo animal se convierte en humano y lo humano en animal. Comer, beber, engendrar, etc., son realmente también auténticas funciones humanas. Pero en la abstracción que las separa del ámbito restante de la actividad humana y las convierte en fin único y último son animales (p. 139-140).

El trabajo enajenado se concreta en los objetos producidos por el trabajador, ya que son extraños a él. El producto del trabajo es su objetivación, el cual se hace extraño al trabajador. Este se apropia del objeto del trabajo porque lo produce, porque lo toca, pero es ajeno a él porque no lo disfruta, por eso la apropiación del objeto o producto del trabajo es extrañamiento y enajenación.

También el trabajo enajenado se puede ver una realización del mismo como desrealización del trabajador porque con su trabajo no puede alcanzar a comer lo suficiente, en otras palabras, trabaja hasta morir por no alcanzarle el beneficio producto de su trabajo para vivir bien. Los dueños de las fábricas van a disfrutar de las ventas de las mercancías producidas, y al obrero le quedará solo una mínima parte para medio subsistir. Para Marx (2013) el exceso debe acabarse porque en la plenitud de una sociedad la miseria se mantiene de igual forma. La teoría económica, estudiada por Marx, dice que la mayor parte del trabajo 
le pertenece al obrero, pero en la práctica recibe solo lo indispensable para subsistir no como humano sino como obrero:

Coloquémonos ahora totalmente en el punto de vista del economicista, y comparemos, de acuerdo con él, las pretensiones teóricas y prácticas de los obreros. Nos dice que, originariamente y de acuerdo con su concepto mismo, todo el producto del trabajo pertenece al obrero. Pero al mismo tiempo nos dice que en realidad revierte al obrero la parte más pequeña e imprescindible del producto; sólo aquella que es necesaria para que el exista no como hombre, sino como obrero, para que perpetúe no la humanidad, sino la clase esclava de los obreros. (p. 72)

En el trabajo enajenado aparece la apropiación como extrañamiento. Esto quiere decir que el obrero se apropia del trabajo sin que no pueda acceder al producto del trabajo; él es también objeto o mercancía producida por el trabajo. Se apropia del trabajo en la medida que el objeto de su trabajo lo extraña, es decir, no puede poseer ese objeto que produce. Y al no acceder al producto de su trabajo sufre una enajenación en su objeto de trabajo. A esto se llama extrañamiento porque padece la pérdida del producto de su trabajo. Y además de ser extrañando se convierte en siervo o esclavo del trabajo, porque solo puede existir como trabajador y como trabajador se convierte en sujeto físico. Es decir, si no trabaja de manera esclava no es ser vivo. $\mathrm{Y}$ al no ser vivo ni siquiera puede existir como humano. Entonces el trabajo esclavo lo deshumaniza. Al final se concluye que el trabajo enajenado lo convierte en esclavo.

El trabajo en general es para Marx (2013) “...La esencia subjetiva de la riqueza...” (p. 167). Pero en el caso del trabajo enajenado es puesto al servicio del capital, es trabajo explotado por no ser bien remunerado. También se pudiera decir que, si el trabajo es esencia de la riqueza y este es hecho por el ser humano, la riqueza humana es puesta al servicio de unos pocos con el trabajo enajenado.

Fromm (1962) dirá que la crítica de Marx al trabajo enajenado va más allá de la justa distribución del ingreso, sino que este trabajo le “...destruye su individualidad...” (p. 60) (al 
trabajador) y “...lo transforma en cosa..." (p. 60). Lo deshumaniza y como ya se ha reflexionado: lo convierte en mercancía. Así como la mercancía se vende el obrero se vende.

Para entender porque se establece el trabajo enajenado se debe entender “...la relación entre trabajador y la producción" (Marx, 2013, p. 138). Con esta relación se descubre que el trabajador no solo se extraña o enajena del producto u objeto del trabajo sino de la misma actividad del trabajador, es una maquina más de la fábrica, se aísla totalmente del trabajo, y este “... se convierte en un poder independiente frente a él...” (Marx, 2013, p. 136).

El trabajo enajenado hace que el trabajador pertenezca a otro y no se pertenezca así mismo, porque "...Está en lo suyo cuando no trabaja y cuando trabaja no está en lo suyo..." (Marx, 2013, p. 139). Es un trabajo exterior a él, lo que lo convierte en un animal por solo poder realizar sus funciones básicas del cuerpo y no poder realizar las actividades humanas del espíritu. De tal manera que no podrá recrearse, pensar, compartir tiempo libre. Marx dirá que el trabajo enajenado "...Lo animal lo convierte en humano y lo humano en animal" (Marx, 2013, p. 139). De todo esto se deduce que el trabajo o se humaniza o siempre será enajenado. Por medio del trabajo el ser humano se dignifica ${ }^{18}$, siempre y cuando pueda estudiar, compartir tiempo libre, dormir lo necesario, cuando aporta lo que sabe para transformar el mundo en más humano y solidario y fraterno. Y por el contrario con el trabajo enajenado no disfruta de su vida espiritual. Dice Pachón Soto (2013):

...quien trabaja 16 horas en una mina: ¿qué tiempo tiene para cultivar sus potencialidades humanas? ¿Qué tiempo tiene para ocuparse de sí, de su crecimiento intelectual y cultural? ¿Qué tiempo para disfrutar la vida, para leer, cantar, pintar, ser crítico? Ninguno. Es un ser miserable, es sólo un trabajador... (p. 36)

\footnotetext{
${ }^{18}$ Marx (2013) hablando del salario lo considera como un servidor del trabajo y no como un fin en sí mismo que realice la dignidad humana: "Un alza forzada de los salarios, prescindiendo de todas las demás dificultades (prescindiendo de que, por tratarse de una anomalía, sólo mediante la fuerza podría ser mantenida), no sería, por tanto, más que una mejor remuneración de los esclavos, y no conquistaría, ni para el trabajador, ni para el trabajo su vocación y su dignidad humanas" (p. 149).
} 
En su relación con la naturaleza el ser humano se sitúa de manera genérica, es decir de manera libre. Se presenta ante ella en su relación consigo mismo y con los demás, ya que el mismo es naturaleza por medio de su cuerpo. De esta relación se puede entender su carácter colectivo porque necesita relacionarse con los otros que son naturaleza, y aunque pueda considerarse individuo a su vez es un ser colectivo. Y de esta la relación ser humanonaturaleza nace de relación hombre-mujer. Marx (2013) lo dice claramente:

...La relación inmediata, natural y necesaria del hombre con el hombre, es la relación del hombre con la mujer. En esta relación natural de los géneros, la relación del hombre con la naturaleza es inmediatamente su relación con el hombre, del mismo modo que la relación con el hombre es inmediatamente su relación con la naturaleza, su propia determinación natural... (p. 172)

Y Cuando por medio del trabajo enajenado no puede disfrutar de la naturaleza, la vida genérica se convierte en algo individual-egoísta, llamada por Fromm (1962) "egotismo existencial" (p. 64); entonces, para lograr ser un humano se debe convertir en individualista dueño de un trabajo enajenado, realizado por otros, de tal manera que estos otros no sean seres humanos. Y será imposible en la práctica que todos los obreros puedan llegar a ser dueños del trabajo de los otros, será entonces una pelea incansable que los irá matando, hasta que no se produzca un cambio en las relaciones de producción, para que estas se den desde la unidad de quienes producen; una unidad para que sea un trabajo que los humanice y cuyo producto alcance para todos. Marx y Engels (2010) en la ideología alemana miran el comunismo como movimiento:

...que revoluciona la base de todas las relaciones de producción que hubo hasta ahora y por primera vez trata de manera consciente todas las condiciones previas naturales como creaciones de los seres humanos anteriores, las despoja de su naturalidad y las somete al poder de los individuos unidos... (p. 161)

Es una unidad de los individuos en la economía para hacerla humana.

Con el trabajo enajenado, el ser humano depende de la naturaleza porque no la transforma para su bien, sino igual que los animales depende de ella para su subsistencia 
física. Renuncia a su ser genérico, como ya se escribió, para ser individual-egoísta, luchando por sobrevivir y no por vivir con dignidad. Es una renuncia a su creación espiritual de la naturaleza:

El trabajo enajenado, por tanto: Hace del ser genérico del hombre, tanto de la naturaleza como de sus facultades espirituales genéricas, un ser ajeno a él, un medio de su existencia individual. Hace extraños al hombre su propio cuerpo, la naturaleza fuera de él, su esencia espiritual, su esencia humana. (Marx, 2013, p. 144)

Entonces el trabajo es un medio para sobrevivir y no fin del ser humano para su libertad, para la creación y admiración, y para su felicidad. Con un trabajo ajeno a él, su ser también lo es, en consecuencia, no es ser humano. Y al ser ajeno a él mismo lo es también a la naturaleza porque el mismo es naturaleza. Fromm (1962) dice que el trabajo enajenado lo aparta de su ser humano: “...le arrebata su vida como especie, su objetividad real como especie y transforma su ventaja sobre los animales es una desventaja, en tanto que su cuerpo inorgánico, la naturaleza, le es arrebatada...” (p. 60). Se enajena de sí mismo porque vive como los animales ${ }^{19}$, solo buscando refugio y alimentos y poniendo su cuerpo al servicio del trabajo, y así el trabajo no está al servicio de su cuerpo y espíritu. Dice Marx (2013) que se pierde a si mismo por un capital viviente, que es el mismo, por este trabajo enajenado:

...En el trabajador se da, pues, subjetivamente, el hecho de que el capital es el hombre que se ha perdido totalmente a sí mismo, de la misma forma que en el capital se da, objetivamente, el hecho de que el trabajador es el hombre que se ha perdido totalmente a sí mismo... (p. 152)

Hasta ahora se ha visto como el trabajo enajenado extraña al trabajador de su producto, de su actividad productiva y de sí mismo, por eso también se le puede llamar enajenación o extrañamiento con la que se siente que todo es superior a él. Fromm (1962) dice:

\footnotetext{
${ }^{19}$ A Marx "...le preocupan aquellas condiciones sociales en las que el objetivo de los individuos se reduce a satisfacer las necesidades físicas elementales. En concreto, afirma que lo más probable es que un individuo que se ve obligado por la pobreza a 'soportar la carga' de las necesidades físicas no solo descuide otras sensibilidades más refinadas [...] sino que además satisfaga esas necesidades de la forma más 'rudimentaria'..." (Leopold, 2012, p. 247)
} 
La enajenación (o "extrañamiento) significa, para Marx, que el hombre no se experimenta a sí mismo como el factor activo en su captación del mundo, sino que el mundo (la naturaleza, los demás y él mismo) permanece ajeno a él. Están por encima y en contra suya como objetos, aunque puedan ser objetos de su propia creación. La enajenación es, esencialmente, experimentar al mundo y a uno mismo pasiva, receptivamente, como sujeto separado del objeto. (p. 55)

Tanto es el extrañamiento, que no puede realizar su historia y esta se le impone desde arriba. Más adelante veremos el materialismo histórico de Marx y Engels, como una historia desde abajo, desde el trabajador. Ahora vamos a explicar cómo se extraña el mismo humano de sus pares.

Se puede decir que cuando se extraña el trabajador, éste entrega el producto, su trabajo y su ser a otro. Es un extrañamiento práctico y material, porque al ser robado su trabajo no lo entrega a una idea abstracta sino a alguien concreto de carne y hueso. Este alguien es el dueño, patrono, quien tiene a su mando los medios de producción. Este extrañamiento o enajenación del trabajo lo entrega el trabajador a un extraño o ajeno a su trabajo, a quien Marx (2013) lo llama "no trabajador" (p. 147). Este "no trabajador" es dueño de la propiedad privada, que es producto de la enajenación. Por este motivo Marx (2013) afirma que “...La propiedad privada es, pues, el producto, el resultado, la consecuencia necesaria del trabajo enajenado, de la relación externa del trabajador con la naturaleza y consigo mismo" (p. 147). Sin duda la propiedad privada lo aleja de los otros seres humanos, principalmente de los patronos o capitalistas, ya que se dan relaciones muy marcadas a partir de esta propiedad-resultado del trabajo enajenado porque "En la relación del trabajo enajenado, cada hombre considera, pues, a los demás según la medida y la relación en la que él se encuentra consigo mismo en cuanto trabajador" (Marx, 2013, p. 145). Si el trabajador se encuentra como no humano, tampoco los demás lo serán, ni sus compañeros obreros ni al patrono, a quien también verá como una máquina, pero no de trabajo físico sino de hacer dinero. Podemos decir que la miseria del capitalismo no solo es causada por el dueño de la empresa, sino por la fuerza del mercado al cual también él está sometido porque:

El dueño que compra el trabajo del obrero a un precio tan bajo que apenas basta para las necesidades más urgentes no es responsable ni de la insuficiencia de los salarios ni de la larga duración del trabajo: el mismo sufre la ley que impone..., 
no es tanto de los hombres como de las fuerzas de las cosas de donde procede la miseria. (Buret en Marx, 2013, p. 107)

El trabajo enajenado extraña al trabajador de los otros seres humanos porque si es enajenado de sí mismo, es decir de su esencia humana, de manera simultánea se extraña de los otros porque "La enajenación del hombre y, en general, toda relación del hombre consigo mismo, sólo encuentra realización y expresión verdaderas en la relación en que el hombre esta con otro" (Marx, 2013, p. 144). Dice Marcuse (1971) que, a partir de la enajenación del obrero de su trabajo, de su producto y de sí mismo nace la enajenación con los otros especialmente en la relación dominio-servidumbre porque “...en realidad, la alienación del trabajo, como enajenación de la actividad propia y de su objeto, ya es en sí la relación entre trabajador y no-trabajador, entre dominio y servidumbre" (p. 57).

Anteriormente se afirmó que la propiedad privada y capital son lo mismo, ahora es necesario agregar que, en consecuencia, también lo es el salario pagado al trabajador, porque si la propiedad y el capital son consecuencia de la enajenación, el salario también lo es porque se paga una mínima parte del capital extrañando al trabajador. Esto lo aclara Marx (2013): “...en el salario el trabajo no aparece como un fin en sí, sino como un servidor del salario...” (p. 148). Entonces el salario lo enajena del capitalista y también de los otros trabajadores que ganan más salario, porque quien gana más, es más importante en el ambiente capitalista. De esta manera “...La sociedad es comprendida entonces como capitalista abstracto” (Marx, 2013, 149). Si la sociedad es "capitalista abstracto" es una enajenación y una discriminación negativa por quien tiene poco capital.

\subsection{Materialismo histórico}

El materialismo histórico es un método humano de abordaje de la historia. Es un mirar la historia desde la realidad social del ser humano. Lo material son las condiciones sociales, políticas y económicas de las sociedades estudiadas por la historia. Marx y Engels (2010) dicen que la historia es la historia del modo como se produce, es una historia material o social: 
...un determinado modo de producción, o una determinada fase industrial, está siempre asociado a un determinado modo de cooperación, o a una determinada fase social, y que este modo de cooperación mismo es una "fuerza productiva"; que la cantidad de fuerzas productivas accesibles a los seres humanos condiciona la situación social, y que, por lo tanto, la "historia de la humanidad" tiene que estudiarse y elaborarse siempre en conexión con la historia de la industria y del intercambio...(p. 58)

Entonces, se cuenta la historia desde la producción y desde ahí se mira las contradicciones entre poseedores del medio de producción y los trabajadores en ese medio de producción, para buscar satisfacer las necesidades materiales de estos. Mondolfo (1977) dice que el materialismo histórico de Marx y Engels:

... aspira a considerar al hombre en su realidad efectiva y concreta; a comprender la existencia del hombre en la historia, y la historia misma como realidad producida por el hombre a través de su trabajo, de su acción social: en el curso de los siglos en que se desarrolla el proceso de formación y transformación del ambiente en que vive el hombre, y se desarrolla el hombre mismo, como efecto y causa a la vez de toda evolución histórica. (p. 12)

El ser humano, como causa y efecto por su trabajo, por su producción, efectúa conciencia, y su vez su conciencia causa verdadera historia de un ser humano en búsqueda de libertad en medio de su producción. Hasta aquí podemos decir con Mondolfo que el materialismo histórico es un "humanismo realista".

Un "humanismo realista" o materialismo histórico que no debe confundirse con un materialismo de Feuerbach, quien, según Marx con su crítica, concebía la realidad como pensamiento y no como actividad sensible, dando como resultado la realidad como mera idea y no como realidad práctica. Es un materialismo que separa el objeto del sujeto, el cual es observado desde afuera sin involucrar el sujeto. Para Marx el materialismo es la integración sujeto-objeto, y esta integración es la actividad humana.

El materialismo de Marx no era el naturalismo de su época. Fromm (1962) dice:

...Este materialismo sostenía que "el" sustrato de todos los fenómenos mentales y espirituales se encontraba en la materia y los procesos materiales. En su forma 
más superficial y vulgar, este tipo de materialismo sostenía que los sentimientos y las ideas se explican suficientemente como resultados de procesos corporales químicos y que "el pensamiento es al cerebro como la orina a los riñones". (2021)

Como se puede observar este no es el materialismo de Marx, ya que él explica los fenómenos mentales y espirituales a través de la praxis del ser humano. Por este motivo se le llama "materialismo histórico" lejos del "...materialismo abstracto de los naturalistas que deja a un lado el proceso histórico..." (Marx en Fromm, 1962, p. 21). Por lo que no es un materialismo pasivo sino activo, no es sólo que la materia la que modifica al ser humano sino él también la modifica, y en esta acción fluye la historia.

El materialismo de Marx nace en la época del idealismo de Hegel, quien considera lo abstracto como esencial mientras que para Marx es lo concreto, lo material, esto es lo esencial. Para el idealismo la actividad del ser humano es abstracta y para el materialismo es sensorial. Así lo explica Marx (2010) en su primera tesis sobre Feuerbach:

El defecto principal de todo el materialismo anterior (incluyendo el de Feuerbach) es que el objeto o la cosa [Gegenstand], la realidad efectiva [Wirklichkeit], la sensibilidad o lo sensible [Sinnlichkeit], sólo es concebido bajo la forma del objeto [epistemológico, Objekt] o de contemplación o intuición [Anschauung]; pero no actividad sensiblemente humana, no como praxis; no subjetivamente. De ahí el lado activo desarrollado abstractamente por el idealismo -que, naturalmente, no conoce la actividad efectivamente real [wirklich], sensible, como tal-, en contraste con el materialismo... (p. 13)

La actividad humana es distinta de los objetos ideológicos o de las ideas.

El materialismo es una respuesta al idealismo. Este pone el centro de la historia en una dialéctica entre las ideas o pensamiento y el espíritu absoluto. Mondolfo (1977) dice que Marx y Engels reaccionan de cara a Hegel:

...Frente a esta concepción, por la cual la subjetividad humana, esto es, la realidad sensible concreta de los hombres, no era -según la frase de Hegel -otra cosa que "materia de la astucia de la razón" universal, trascendente, Marx y Engels reaccionan afirmando que esa pretendida materia de la astucia de la razón, -es 
decir, los hombres, la humanidad- era, en cambio, la verdadera realidad, central y fundamental, del mundo y de la historia. (p. 16)

La realidad o actividad del ser humano es la que responde y crea conciencia, y según Hegel, es materia para ser pensada según el absoluto o razón universal y luego imponer una idea que no corresponde a la realidad de la actividad. Un espíritu absoluto que puede ser quienes en nombre de este quieren mantener sus privilegios y exclusiones. Es la historia de los dominadores o de la burguesía, que según Korsch (1978) cree haber cerrado la dialéctica idealista:

...el movimiento dialectico debe hacer alto irrevocablemente, hoy y en el futuro, en el punto final absoluto en el que lo dejó el último filosofo revolucionario de la clase burguesa, Hegel. No debe sobrepasar con sus conceptos los límites que la misma sociedad burguesa tampoco puede sobrepasar en la realidad, sin eliminarse a sí misma. Su última palabra, la gran síntesis universal en la que son abolidas o pueden ser abolidas todas las contradicciones, es el Estado... (175-176)

Entonces, la burguesía, respaldada por el Estado Burgués es el absoluto ${ }^{20}$, quien no tiene antítesis, y quien se atreva a criticarla queda “...fuera del derecho burgués, de la libertad burguesa y de la paz burguesa, y por consiguiente también fuera de toda filosofía y ciencia burguesa..." (Korsch, 1978, p. 176). Porque la libertad, dice Marx y Engels (2007), es la libertad para seguir considerando al obrero una pieza más de su fábrica: "Por libertad, en las condiciones actuales de la producción burguesa, se entiende la libertad de comercio, la libertad de comprar y vender" (p. 27).

El materialismo histórico distingue una historia dominadora a una humana donde estos (humanos) se rebelan contra el dominador para luego mandar en el sentido de humanizar. Desde este punto de vista se puede entender el poder de los proletariados, como un poder para humanizar.

Es la historia desde la lucha de los pueblos. Así lo confirman Marx y Engels (2007):

20 “....Es evidente que los 'fantasmas', los 'lazos', el 'ser superior', el 'concepto', la 'duda', son meramente la expresión intelectual idealista, la idea aparentemente del individuo aislado, la idea de trabas y limites muy empíricos, dentro de los cuales se mueve el modo de producción de la vida y las relaciones de producción ligadas a él" (Marx y Engels, 2010, p. 64). 
La historia de todas las sociedades hasta nuestros días es la historia de las lucha de clases. Hombres libres y esclavos, patricios y plebeyos, señores y siervos, maestros y oficiales, en una palabra: opresores y oprimidos se enfrentaron siempre, mantuvieron una lucha constante, velada unas veces y otras franca y abierta; lucha que terminó siempre con la transformación revolucionaria de toda la sociedad o el hundimiento de las clases en pugna. (p. 7-8)

La historia desde el materialismo hace ver que existen humanos que la realizan y otros a los cuales se la realizan, mejor dicho, son presas de una falsa historia porque no logran beneficiarse de ella.

El materialismo de Marx tampoco debe ser confundido y menos reducido a la necesidad única de lo material para dejar de lado lo espiritual. Según Fromm, Marx quiere liberar al hombre de las presiones que forjan las necesidades materiales y sobre todo las creadas o falsas o "necesidades no necesarias". Una cosa es liberar al ser humano de sus necesidades materiales falsas o creadas, otra es utilizar a Marx para decir que sólo se preocupaba que el ser humano tuviera cosas materiales para ser feliz. Esto es una reducción y no el materialismo de Marx. Este consiste en la satisfacción de las necesidades materiales y espirituales, pero sin llegar a un consumo exagerado. Este consumismo es un tipo de materialismo de nuestra época llamado hedonismo, o placer por el placer o "placer irresponsable".

El materialismo de Marx, como se ha dicho, no implica afán por el mismo, sino cubrimiento del mismo producto del trabajo. Es un beneficiarse de lo material por ser el humano esencia material, para vivir como tal y no como animal. Entonces, si los medios de producción no cubren las necesidades del ser humano, estos están al servicio de unos pocos y no de la mayoría. Fromm (1962) explica muy bien el materialismo de Marx como teoría histórica y no como impulso materialista:

La interpretación "materialista" o "económica" de la historia no tiene nada que ver con un supuesto impulso "materialista" o "económico" como el impulso fundamental del hombre. Significa que el hombre, el hombre real y total, "los individuos realmente vivos", -no las ideas producidas por estos "individuos"- son el tema de la historia y de la comprensión de sus leyes. La interpretación marxista de la historia podría llamarse una interpretación antropológica de la historia, si se 
quisiera evitar las ambigüedades de los términos "materialista" y "económico"; es la compresión de la historia basada en el hecho de que los hombres son "autores y actores de su historia”. (p. 24-25)

Las obreras y obreros serán "autores y actores de su historia” si logran emanciparse, de lo contrario serán consecuencia de la misma. Este es el gran aporte de Marx: sumar a los oprimidos como historia y no solo a los ricos y poderosos. Esta es la historia materialista ${ }^{21} \mathrm{o}$ materialismo histórico de Marx.

21 "Otra lección importante de la historia que Marx construye [...] es su dimensión como historia materialista. No en el sentido vulgar, aunque a veces repetido, de que lo 'espiritual' sea un simple 'reflejo directo o dependiente de lo material sino más bien en la línea de que, en general, es imposible explicar adecuadamente los procesos culturales, las formas de conciencia, los elementos del imaginario social, las figuras de la sensibilidad colectiva, etcétera, sin considerar igualmente las condiciones materiales en que se desenvuelven y apoyan esos productos, y esas manifestaciones diversas de los fenómenos intelectuales y de la sensibilidad humana en general" (Aguirre Rojas, 2010, p. 83). Se da una síntesis entre lo material y espiritual. 


\section{Antropología y humanismo en el socialismo del siglo XXI}

El segundo capítulo descubrirá por medio de los autores citados y las propias reflexiones la antropología y el humanismo presentes en el socialismo del siglo XXI. Para abordar este capítulo primero se narrará una breve historia de este socialismo, luego se tocarán puntos importantes como: emancipación de la mujer, inclusión de los indígenas, campesinos, movimientos sociales, trabajadoras y trabajadores, consejos comunales, socialismo cristiano, socialismo bolivariano, socialismo e interculturalidad, y por ultimo socialismo e integración latinoamericana.

\subsection{Breve historia del socialismo del siglo XXI}

El socialismo del siglo XXI surge como una respuesta al llamado fin de la historia planteado por Fukuyama, después de la caída del muro de Berlín y la caída de la Unión Soviética. Y surge también como respuesta comprensiva y racional de las contradicciones del capitalismo. Podemos decir que se comienza a fraguar a finales del siglo $\mathrm{XX}^{22}$ y nace

\footnotetext{
22 “Las bases del socialismo del siglo XXI como movimiento no son teóricas sino, muy al contrario, beben de realidades bien concretas -esto siempre es así, pero se pierde de vista en los análisis de grandes plazos y grandes estructuras. E incluso, los referentes teóricos más influyentes han estado mucho más cerca de coyunturas concretas que de discusiones de libros sobre libros. Las bases del socialismo del siglo XXI hay que buscarlas (aun sin ánimo exhaustivo) en los siguientes sucesos y en las reflexiones que abrieron: el derrocamiento de la Primavera de Praga en 1978 por las fuerzas del Pacto de Varsovia; la creación del sindicato polaco disidente Solidaridad en los astilleros de Gdansk, en 1980; las victorias de la derecha en Europa y Estados Unidos (Juan Pablo II-1978; Thatcher-1979, Reagan- 1980, Kohl-1981); la caída del Muro de Berlín de 1989; el nombramiento de Carlos Salinas en México en 1988, de Carlos Saúl Menem en Argentina y de Carlos Andrés Pérez en Venezuela, ambos en 1989; la pérdida del poder de los sandinistas en 1990; la enunciación del Consenso de Washington en 1990; la disolución de la URSS en 1991; el levantamiento zapatista de 1994; la fundación en 1980 de Los Verdes en Alemania (con las banderas del socialismo, el ecologismo, la democracia de base, la no violencia y el antiautoritarismo); el desarrollo de la teología de la liberación, con la fecha
} 
formalmente con el inicio de los gobiernos de izquierda de Venezuela, Bolivia y Ecuador ${ }^{23}$, fruto de luchas de movimientos sociales desde hace varias décadas. Al primer líder político que se le escucha hablar de socialismo del siglo XXI es Hugo Chávez Frías, quien lo pronuncia por primera vez en un discurso. Dieterich (2008) citando a Chávez dice lo siguiente:

Con un fuerte cañonazo hacia el campo de las ideas, el Presidente Hugo Chávez sacudió el 27 de febrero del año 2005 las bucólicas discusiones de intelectuales y políticos sobre el futuro de la humanidad. Mencionó lo inmencionable y pidió lo que no se debe pedir: un debate a fondo, sin tabúes ni exclusiones, destinado a buscar una alternativa para el género humano, más allá del capitalismo actual y de la socialdemocracia. Hugo Chávez se catapultó a la vanguardia del debate mundial, al proclamar la necesidad de "seguir alejándonos del capitalismo" e “inventar el socialismo del siglo XXI". Caso seguido, el Comandante reforzó su posición, enfatizando que el socialismo en Venezuela sería de carácter democrático y participativo, "en concordancia con las ideas originales de Carlos Marx y Federico Engels”. (p. 9)

Chávez dará forma política y teórica con el socialismo del siglo XXI a los movimientos sociales (profesionales de clases media, educadores populares, clase obrera, comunidades católicas de base, estudiantes, mujeres, etc.) y militares nacionalistas que venían en Venezuela desde el Caracazo en 1989 y el golpe militar de 1992, buscando participación política, justicia social y un nuevo estado dispuesto a saldar la enorme deuda social de los gobiernos de la llamada cuarta república (desde 1958 a 1998).

Luego de Chávez, vendrá Evo Morales y su vicepresidente Linera quienes asumirán, a partir del año 2006 un liderazgo para incorporar a los indígenas bolivianos en la construcción

emblemática de 1973, cuando el peruano Gustavo Gutiérrez Merino editó el primer libro sobre el tema Historia, política y salvación de una teología de liberación (que obligaría a pluralizar el sujeto); etc." (Monedero, 2008, p. 78-79).

23 “...Una izquierda digna de ese nombre solo lo es en la medida de su radical anticapitalismo. Por eso, solamente gobiernos como los de Cuba y en menor medida (habida cuenta de su corta experiencia en términos históricos) los de Venezuela, Bolivia y Ecuador califican como gobiernos de izquierda... (Borón, 2014, p. 240). 
de un nuevo modelo de participación política y social con ellos a la cabeza y así ser parte del nuevo socialismo, llamado por ellos socialismo comunitario.

Después vendrá Correa, en 2007, con su revolución ciudadana para construir el socialismo del siglo XXI. Igual que Chávez, Correa dará forma de poder de gobierno constitucional a los reclamos de los movimientos sociales e indígenas del Ecuador.

Al ascenso de los movimientos sociales al poder, Correa (citado por Montes del Castillo, 2009) lo llamará revolución ciudadana en su mensaje ante la Asamblea Nacional Constituyente al cumplirse el primer año de gobierno, en enero de 2008:

Las políticas impulsadas en este año por el gobierno de la Revolución Ciudadana han cambiado radicalmente los principios y orientaciones, privilegiando al ser humano por sobre el capital, la aventura de la dignidad a la nefasta solvencia del servilismo, la minga a la competencia. (p. 204)

Como puede analizarse, Correa recoge el espíritu de minga o de cooperación gratuita del pueblo ecuatoriano para proponer un estilo de vida socialista y humano por encima del capital y del servilismo o esclavitud. En otro discurso (01 de mayo de 2007) Correa explicará como por medio de estas luchas de los movimientos sociales de poner el trabajo sobre el capital, se puede fomentar y consolidar el socialismo del siglo XXI. Dice Correa:

La herencia, lo dije en el discurso de transmisión de mando y se lo repito en este uno de mayo, la herencia más nefasta de esta larga y triste noche neoliberal ha sido la explotación de nuestra fuerza laboral, tratada como un instrumento más de acumulación, que hay que utilizarlo en función los requerimientos del capital, el trabajo en función del capital, qué barbaridad, qué inmoralidad. El trabajo humano, compatriotas, obreros y obreras de mi patria, no es un medio más de producción, es el fin mismo de la producción. Todo debe estar en función del trabajo humano, lo más sagrado que existe. Y aquí, como decía el compañero Arciniegas, se lo ha tratado como una mercancía: comprar, vender o botar cuando ya no sirve. Y se ha exacerbado la explotación laboral. Esto que les acabo de mencionar es doctrina social de la iglesia, encíclica Laborel Excelsem de Juan 
Pablo II. Pero es la característica fundamental del socialismo de siempre y, por supuesto, del socialismo del siglo XXI. La supremacía, escúchenme bien, la supremacía es del trabajo humano sobre el capital. Así que entérense todos, en este país, en este gobierno de la revolución ciudadana, el capital y todos los demás factores de producción deberán estar en función del trabajo humano y no lo contrario, cómo la locura que se ha vivido hasta ahora, compatriotas. (p. 5-6)

Y lo dicho por Correa no se quedó en el papel, sino que a partir de su mandato tomó decisiones en favor de las trabajadoras y trabajadores con el aumento del sueldo mínimo, aumento de salarios a los profesores y médicos y demás personal de salud y abrió nuevas plazas para los educadores públicos.

En la actualidad (2018) el socialismo del siglo XXI como propuesta teórica se encuentra en una fase de desconfianza por las crisis política y social de Venezuela y la crisis de corrupción en Ecuador. Ya se dijo en la introducción que por el hecho que una teoría no se lleve a cabo totalmente en la práctica, no quiere decir su fracaso. Tanto en Venezuela como en Ecuador se espera las respuestas de los movimientos sociales de base, para que ellos puedan de veras guiar estos procesos. Ellos son la realidad y a partir de ahí surgirán liderazgos colectivos que mantengan los avances sociales que no son informados en los poderosos medios de comunicación capitalistas. ${ }^{24}$

\footnotetext{
${ }^{24}$ Monedero (2014) hace una especie de predicción de lo que está pasando (año 2018) en los procesos socialistas del siglo XXI, una autocrítica y una posible respuesta de los pueblos organizados: “...la falta de diálogo con los sectores críticos rebajará la base de apoyo a los gobiernos de cambio, poniendo en peligro su subsistencia electoral (a diferencia de la izquierda propia de la Guerra Fría, la nueva izquierda se juega todo lo alcanzado en las elecciones). La creación de redes clientelares en los gobiernos, la política extractivista, la falta de diálogo con los indígenas o con los sectores desobedientes, la desaparición de la crítica (uno de los rasgos centrales que diferencian los actuales procesos de cambio de cualquier otra revolución en el pasado), la creación de nomenklaturas que aprovechen la posición de poder en el entramado estatal, el freno a los procesos de empoderamiento popular, son todos aspectos que volverán a achicar la base de apoyo a estos gobiernos. La tesitura no es sencilla y parece claro que hay que garantizar tanto la eficiencia gubernamental que logre mejores niveles de vida como la participación popular que vaya permitiendo una superación del modelo heredado. Una certeza es incuestionable: si se puede hablar hoy de la posibilidad del socialismo del siglo xxi es porque hay un pueblo dispuesto a luchar por él" (p. 233).
} 


\subsection{Emancipación de la mujer como signo del socialismo del siglo XXI}

El sistema socialista mira a la mujer en igualdad de condiciones que al hombre. La mujer es vista en el sistema capitalista como subordinada al varón. Son iguales porque ambos deben aportar a la sociedad. El machismo y la debilidad de la mujer son creaciones occidentales para dominar. Un hombre dominando a una mujer, no solo la domina a ellas, sino que domina a los hijos y así puede el hombre como tal dominar a la sociedad.

Sin participación de la mujer y sin su emancipación no existe socialismo porque la igualdad entre seres humanos se entiende a partir de la igualdad entre hombres y mujeres, igualdad económica, cultural y política. Dice Blanco (2007) que el feminismo garantiza una sociedad socialista:

...Ya muchas feministas comunistas comprendieron en el desarrollo del llamado socialismo real que vencer o transformar el sistema capitalista por el socialista no era suficiente para cambiar las relaciones de dominación entre los sexos y la discriminación hacia la mujer, si no se cuestionaba y se derrumbaba en todos los niveles el modelo cultural de dominación androcéntrico que le servía a su vez de plataforma al capitalismo; de no revisar este legado histórico corremos el riesgo de seguir reproduciéndolo y así como ocurrió con el socialismo decimonónico podría volver a ocurrir en el siglo XXI. (p. 95)

Ser feminista por sí solo no garantiza emancipación. El feminismo puede ser visto como

liberación de la mujer blanca y heterosexual. El feminismo socialista es redentor también de la raza y de la homosexualidad femenina y masculina. Lugones (2008) establece esta relación entre feminismo, raza, y orientación sexual:

En el desarrollo de los feminismos del siglo XX, no se hicieron explícitas las conexiones entre el género, la clase, y la heterosexualidad como racializados. Ese feminismo enfocó su lucha, y sus formas de conocer y teorizar, en contra de una caracterización de las mujeres como frágiles, débiles tanto corporal como mentalmente, recluidas al espacio privado, y como sexualmente pasivas. Pero no explicitó la relación entre estas características y la raza, ya que solamente 
construyen a la mujer blanca y burguesa. Dado el carácter hegemónico que alcanzó el análisis, no solamente no explicitó, sino que ocultó la relación. Empezando el movimiento de «liberación de la mujer» con esa caracterización de la mujer como el blanco de la lucha, las feministas burguesas blancas se ocuparon de teorizar el sentido blanco de ser mujer como si todas las mujeres fueron blancas. (p. 95)

Las mujeres blancas burguesas no incluyeron a las mujeres negras, indígenas, campesinas, obreras porque ellas mismas fueron y son promotoras del machismo capitalista para sustituirlo por el feminismo capitalista. Ha sido un feminismo burgués para ellas por ser parte del poder patriarcal.

El feminismo burgués es visto, como ya se afirmó, como respuesta a ser vistas como débiles, por eso se aleja del feminismo socialista, ya que las mujeres oprimidas eran juzgadas como agresivas y malas y por eso debían ser dominadas. En lo popular o en el machismo popular costeño, campesino y llanero, colombiano o venezolano se dice que la mujer perjudica todo, por eso debe ser dominada. Dice Lugones (2008):

Históricamente, la caracterización de las mujeres Europeas blancas como sexualmente pasivas y física y mentalmente frágiles las colocó en oposición a las mujeres colonizadas, no-blancas, incluidas las mujeres esclavas, quienes, en cambio, fueron caracterizadas a lo largo de una gama de perversión y agresión sexuales y, también, consideradas lo suficientemente fuertes como para acarrear cualquier tipo de trabajo... (p. 96-97)

Fue caracterizada la mujer pobre como animal. Por este motivo el feminismo socialista es distinto al feminismo burgués porque quiere que la mujer asuma su protagonismo como ser digna y humana. Blanco (2007) agrega que existen distintos tipos de feminismo por la relación entre clase social y feminismo:

... aunque pueda señalarse que el conjunto de las mujeres padece discriminaciones legales, educacionales, culturales, políticas y económicas, lo cierto es que existen, a su vez, evidentes diferencias de clases entre ellas que moldearan, no sólo las vivencias subjetivas y objetivas de la opresión sino sus posibilidades objetivas de enfrentamiento, resistencia y superación de estas condiciones socio-culturales de 
discriminación. De ahí que se desprendan corrientes de feminismo obrero, socialista y marxista y, por otro, feminismo burgués, y aunque ambos están compuestos por mujeres que luchan contra el sistema patriarcal, su posición de clases determina su posición ideológica. (p. 89)

Por lo tanto, la participación de la mujer en la edificación del socialismo del siglo XXI es indispensable. Ella es motor de la auténtica revolución socialista del siglo XXI. Además de valioso aporte en igualdad con el hombre, ella que ha sido víctima de un sistema patriarcal y su relación con la raza, clase y cultura oprimida, es clave para superar la explotación a la que es sometida grandes mayorías del mundo por la lógica del capital. Superándose la mujer obrera, indígena, negra, campesina, se supera la indignidad del ser humano esclavo del capitalismo.

\subsection{Indígenas y socialismo del siglo XXI}

A partir de la subida al poder de Evo Morales Ayma, originario aymara y líder sindical cocalero, como primer presidente indígena de Bolivia, nace de manera oficial la relación entre el socialismo del siglo XXI y los indígenas, con la consecuente originalidad de la participación de este poder popular. Con este hito histórico se marca con fuerza la llegada de estos a un poder controlado solo por blancos en un país de mayoría aborigen. Dice Stefanoni (2008):

El 22 de enero de 2006 fue vivido por una gran mayoría de bolivianos como un parte aguas en una historia nacional que pasó del colonialismo español al "colonialismo interno"; un sistema formalmente republicano en el que el color (más blanco) de la piel, los apellidos españoles y el dominio del castellano devinieron un "capital" necesario para acceder a los espacios de decisión política, acumulación de riquezas y construcción de prestigio social. Ese día llego a la presidencia Evo Morales Ayma indígena aymara y dirigente de los sindicatos de cultivadores de coca en el Trópico de Cochabamba. (p. 253).

La propuesta de Evo Morales de una asamblea nacional constituyente y la nacionalización del gas convenció a la mayoría indígena de Bolivia, quien lo votó como su 
presidente. Esta propuesta es llamada un nacionalismo indígena que entra a formar parte del socialismo del siglo XXI, como emancipación de las clases campesinas muy parecida a la indígena por sufrir discriminación y exclusión. Evo Morales como parte del Movimiento al Socialismo Boliviano (MAS) se sirve de esta idea y la ganan en las elecciones presidenciales. Explica Stefanoni (2008) como el MAS aplica el marxismo para liberar a los indígenas: “...La mención del marxismo como uno de los ejes ideológicos masistas tiene principalmente el objetivo de resaltar la dimensión clasista que atraviesa al movimiento indígena -que se piensa a sí mismo como campesino- ...” (p. 257). Y más allá de la clase está el sentido de pueblo indígena que se contrapone a la oligarquía o clase dominante y también una "...etnificacion (no excluyente) de la política..." (Stefanoni, 2008, p. 258), como acceso de las etnias a la participación política, social y económica desde su visión del respeto a la naturaleza y la vida en común. "Etnificación" de la política por la sabiduría ancestral y comprobada de ellas, para asimilar de ellas en la construcción del socialismo nuevo del siglo XXI, como explica Mosonyi (2007):

¿Hasta cuándo tardaremos en comprender que el socialismo necesita de insumos originales e inéditos para su renovación y repotenciación, en lugar de la práctica tan común de seguir aplicando recetas triviales y fracasadas? Diremos una y mil veces que atosigar a los pueblos indígenas con fórmulas socializantes eurocéntricas no sólo puede matar en germen cualquier contribución propia emanada de la sociodiversidad sino que puede hasta revestir un carácter tragicómico; porque si alguien sabe por experiencia milenaria de comunidades y de convivencia solidaria entre la gente y con la naturaleza son precisamente los indios americanos, especialmente aquellos que nunca estuvieron organizados en grandes imperios ni se dedicaron a la conquista bélica de otras sociedades. Lo mismo vale para las microetnias de otros continentes. Exportarles ahora desde nuestras capitales el esquema comunitario parece casi una burla; es como llevar baldes de agua al océano. Por favor, recuperemos la sindéresis y tratemos de aprender algo nuevo y distinto de otros pueblos, aunque sea por primera y única vez en nuestra vida. A veces pienso que nuestra soberbia trasciende todo límite imaginable. (p. 186) 
También Chávez (2006) en el llamado "discurso de la unidad"25 del 15 de diciembre de 2006, propone el socialismo del Siglo XXI con características indígenas:

Vamos a relanzar el socialismo indo-venezolano, un socialismo inspirado en nuestras propias raíces. Debemos incorporar repotenciándolo, actualizándolo, el socialismo indígena o indo-venezolano. Tenemos que respetar y ayudar a fortalecer esas raíces de nuestro socialismo. Esas prácticas son como una semilla que debe expandirse, multiplicarse. Fijense, es al revés de lo que mucha gente ha planteado. Mucha gente ha dicho: "Vamos hasta las comunidades indígenas para ayudarlos"; más bien, deberíamos decir: "Vamos a pedirle ayuda a ellos para que cooperen con nosotros en la construcción del proyecto socialista del siglo XXI". Me decía el gobernador Rangel Gómez hace poco, allá en Bolívar, conversando, que él se ha dado cuenta de cómo los consejos comunales, por ejemplo, funcionan mucho más rápido y con mayor eficiencia en las comunidades indígenas. Eso es lógico porque es su cultura de siglos. La nuestra, por el contrario, está envenenada de capitalismo, individualismo, egoísmo. Ellos mantuvieron sus tradiciones porque los obligaron a replegarse hasta zonas alejadas, hasta las riveras del Capanaparo, la Sierra de Perijá, el Delta del Orinoco, las selvas de Amazonas, la Paragua y más allá, hacia las regiones fronterizas.

Chávez toma en su propuesta teórica lo dicho por Mariátegui cuando afirmaba que el socialismo de América no debe ser copia del europeo, sino un socialismo indoamericano propio y original. ${ }^{26}$ Para Mariátegui el materialismo marxista produce valores espirituales. El marxismo de Mariátegui se acerca a la filosofía de la praxis, la ética, humanismo y conciencia revolucionaria de América Latina. No es una lectura nueva del marxismo sino un instrumento aplicado a la realidad latinoamericana.

Este socialismo indígena parte de recoger las ideas de la vida social de los indígenas para aplicarlas a la sociedad venezolana. El venezolano tiene una herencia de la forma de ser de los Caribes, tribu que vivía en la costa de lo que hoy es llamada Venezuela. Los españoles encontraron fuerte resistencia de ellos hasta tal punto de tardar un siglo para poder

\footnotetext{
${ }^{25}$ En este discurso, pronunciado en Caracas, Chávez llama a conformar un partido único socialista con el objetivo de reunir a todos los partidos y movimientos de izquierda. En:http://www.manuelugarte.org/modulos/biblioteca/c/chavez/chavez.htm

26 "No queremos, ciertamente, que el socialismo sea en América calco y copia. Debe ser creación heroica, tenemos que dar vida, con nuestra propia realidad, en nuestro propio lenguaje, al socialismo indoamericano. He aquí una misión digna de una generación nueva...capitalismo o socialismo. Este el problema de nuestra época. No nos anticipamos a las síntesis, a las transacciones, que sólo puede operarse en la historia". (Mariátegui, citado por Rodríguez, 1985, p. 116)
} 
dominarlos. En efecto las primeras guerras de conquistas fueron perdidas por los conquistadores españoles. También los caribes vivían de manera comunitaria sin jerarquías. Para los caribes la guerra era parte de un ritual de vida, para su defensa, pero no era para dominar. $^{27}$

De este pensamiento Caribe se pueden extraer enseñanzas para el socialismo. Se puede vivir de manera comunitaria sin jerarquías, pero con autoridades para ayudar a mantener el orden. El cacique en las comunidades indígenas venezolanas tiene autoridad, pero no jerarquía. Ella se impone, la autoridad dialoga y luego hace cumplir lo dialogado. El socialismo indígena no pretende que vivamos exactamente como ellos, pero sí que aprendamos de ellos su convivencia sana con la naturaleza. Aprender de ellos y que ellos aprendan de nosotros, como dice Paulo Freire (1970) "Ahora, ya nadie educa a nadie, así como tampoco nadie se educa a sí mismo, los hombres se educan en comunión, y el mundo es el mediador..." (p. 92)

Aprender de los indígenas, de su vida social y saberes para curarse de enfermedades, y así construir el socialismo del siglo XXI sin comercializar la medicina, como lo hacen los indígenas venezolanos. De esto dice Mosonyi (2007):

...hay que recordar que Venezuela cuenta con un alto número de comunidades que hasta el presente han tenido muy poco contacto y una mínima compenetración con el mundo envolvente, y que quizás por esto tengan muchísimo que ofrecernos en materia de originales aportes socioculturales, tecnoeconómicos y políticos [...] Me refiero, por ejemplo, a los múltiples conocimientos botánicos, biomédicos, tecnológicos ahorradores y la psiquiatría social de raíz chamánica y profundamente espiritual. Aquí estarían algunos aportes a futuro dentro de una concepción más amplia y dinámica de un socialismo del siglo XXI. (p. 185)

\footnotetext{
27 “Los caribes podían guerrear unos días y luego regresar a conversar con los vencidos, sin establecer mecanismos de dominación o exterminio propios de sociedades clasistas, es la comprensión del mundo sin clases sociales, de una cosmogonía basada en lo ritual cotidiano y no en la guerra de supresión aplicada por los españoles para la esclavización de los sometidos por la fuerza." (Barrios Romero, 2007)

En http://www.aporrea.org/ideologia/a39406.html.
} 
También se puede rescatar de los indígenas su humanismo en su sentido de armonía de unidad en la diversidad y de respeto por la idea de los otros. Y aunque no estén de acuerdo con las decisiones del colectivo ellos saben posponer sus propias ideas y llevar a la práctica lo consensuado. Dice Mosonyi (2007):

...el consenso no mata la diversidad de pensamiento y el adherirse a una solución permite todavía que ciertos individuos y familias mantengan en reserva algunas ideas distintas. Así, dentro de una comunidad parece lógico que unos ejecuten las obras con mayor entusiasmo que otros, les dediquen tal vez mayor tiempo y esfuerzo, mientras que algunos permanecen discretamente en la retaguardia sin sabotear jamás y sin llevarle abiertamente la contraria a lo que decidió el colectivo. Esto permite que en la medida en que fracase o sea insuficiente lo resultante de un consenso logrado, haya todavía otros recursos que posteriormente podrían ponerse en práctica a base de otras discusiones y eventualmente un nuevo acuerdo. Lo llamativo es el mantenimiento de la armonía, pues una comunidad indígena prefiere dividirse y marcharse cada uno por su lado antes que mantenerse juntos con iras y reconcomios... (p. 183-184)

Esto es un socialismo humanista porque se resalta que cada individuo pensante es un ser un humano en el beneficio social, pero sin renunciar a su individualidad y humanidad con dignidad, a su ser distinto de los otros. Es un socialismo basado en un indigenismo que respeta lo individual, aunque se trabaje en colectivo. Explica Mosonyi (2007):

Las propuestas indígenas están basadas en la diversidad interna y externa de cada sociedad participante (Grupo de Barbados, 1993), con énfasis en las microsociedades -muy diferenciadas entre sí- de orientación comunal. En estas comunidades observamos una amplísima tolerancia frente a todo tipo de manifestaciones individuales, siempre y cuando no amenacen decididamente la convivencia de los copartícipes ni la sostenibilidad histórica de la sociedad como tal. Esa misma tolerancia se extiende a los representantes de otras formaciones sociales, incluidas las occidentales. (p. 188)

Se viene hablando de asimilar las prácticas comunitarias de los indígenas como ingrediente del socialismo, lo cual le fue difícil, por no decir imposible, para ciertos marxistas del siglo XX. Esto por su visión lineal y teleológica de la historia. Y entonces al no ser posible establecer un capitalismo en los indígenas, le era imposible una posterior instauración del socialismo comunista. Esto hizo que los movimientos indígenas estuvieran fuera de la izquierda latinoamericana, con la excepción de Guatemala. De esta manera, aunque el 
marxismo latinoamericano del siglo $\mathrm{XX}$, con algunas excepciones, no le dio importancia al movimiento indígena, ha habido en este siglo un acercamiento entre marxismo e indianismo, es más el marxismo ha cohesionado los movimientos indígenas. García Linera (2008) considera que, gracias a la izquierda se puedo cohesionar los movimientos indígenas en el siglo XXI. Dice este autor:

De hecho es posible apuntar que el éxito, o parte del éxito, un elemento pequeño que ha contribuido a la construcción de un movimiento popular indígena con la suficiente fuerza de movilización, en los años 2000-2006, y buena parte de las estrategias de alianzas que se han podido articular entre movimientos indígenas, movimiento obrero, sector urbano juvenil, se debe a muchos elementos. En primer lugar, por supuesto, a las características del momento, una nueva generación de líderes sociales, pero también, a manera bastante humilde pero interesante de ser tomada en cuenta, a una distinta manera de acercamiento de núcleos marxistas al desarrollo de estos movimientos y a la búsqueda de un diálogo entre una trayectoria planetaria del movimiento marxista y los aportes locales y generales del propio movimiento indígena. (p. 116-117)

García Linera, apoyado en Marx, explica que se puede considerar la economía y la cultura indígena parte del capitalismo por la subsunción de esta al mismo. Por eso hoy en día con más razón la explotación de las comunidades indígenas al ser parte del capitalismo es una razón para que ellos aporten toda su sabiduría por el buen $\operatorname{vivir}^{28}$ y el socialismo del siglo XXI. El tercer capítulo explicará mejor este encuentro teórico-práctico entre socialismo indígena y marxismo. García Linera (2008) habla de esta subsunción diciendo lo siguiente:

En particular consideramos que en la teoría crítica marxista existen al menos cuatro grandes líneas teóricas que ayudan, que pueden ayudar y están ayudando a un acercamiento, a un ensamblaje critico-revolucionario entre marxismo e indianismo. Menciono estas cuatro líneas y las trabajo: 1. La teoría del desarrollo del capitalismo como proceso de subsunción formal y de subsunción real del proceso de trabajo bajo el capital 2. La teoría de la nación y de la colonialidad al

\footnotetext{
${ }^{28}$ La teoría del buen vivir de los indígenas bolivianos es un aporte al socialismo del siglo XXI, pero según Katz (2014), este no puede reducirse al mismo: “García Linera estima que en Bolivia -al igual que en Ecuador, México, India o partes de África -es factible desenvolver formas comunitarias de socialismo. Recoge especialmente sugerencias que planteó Mariátegui para tender puentes entre comunismo y el indianismo. Existen muchas interpretaciones unilaterales de este proyecto como simple sinónimo del 'buen vivir'. Omiten que la recomposición de la armonía del ser humano con la naturaleza constituye sólo una meta de un programa concebido para el Altiplano. Es importante subrayar que no es un modelo universal, aplicable a países forjados en otras tradiciones" (p. 72).
} 
interior de las sociedades capitalistas 3. La teoría de las formas de la comunidad y 4. La teoría de la revolución y el poder. (p. 117).

Como se explica acá, ya puede darse una lucha marxista de superación de clases sociales en Latinoamérica indígena y campesina, porque para el capitalismo los indígenas y los campesinos son iguales a la clase obrera, son clase oprimida y excluida de los beneficios del capital.

Otro autor de apellido Bosteels (2016) escribe que Marx habló de un capitalismo no igual desarrollado que el de Europa. Suaviza su visión dura lineal de la historia. Este autor reflexiona esta idea para hablar de los desencuentros entre Marx y Martí, pero a la vez para afirmar que estos desencuentros permiten ver que la realidad latinoamericana es distinta a la de época de Marx, y a pesar de estos pueden darse encuentros que permitan desarrollar una sociedad socialista en América Latina. Dice este autor al hablar de las diferencias entre Marx y Martí:

Esto no quiere decir que nos queden solo encuentros fallidos o negativos entre Marx y América Latina, o entre Marx y Martí. Al contrario, como empecé a formular arriba, la lógica del encuentro fallido o el desencuentro puede ser considerada un nombre, entre otros, para el desarrollo desigual del capitalismo en su fase global. Esto incluso podría abrir el espacio para una apreciación renovada de la idea del encuentro, no como eufemismo para el descubrimiento y la colonización de América Latina, sino en el sentido en que el último Louis Althusser lo usa para configurar lo que le llamaba la "corriente subterránea" de un "materialismo aleatorio", basado en encuentros azarosos, en oposición al supuesto determinismo y etapismo de las versiones tradicionales, dogmática o vulgares del materialismo historio y dialectico[...] Al fin y al cabo, especialmente a partir de los años 1870, Marx también empezó a formular una serie de hipótesis acerca del desarrollo desigual que le permitieron generalizar una lógica de la contingencia y la desigualdad para todo capitalismo y no solo para los países llamados periféricos, atrasados, semicapitalistas o coloniales... (p. 43-44)

Esta idea puede ser base para un comunismo que se establece en regiones como la nuestra en que el capitalismo no ha sido desarrollado a su máxima expresión. Por esto los 
campesinos e indígenas bolivianos, aunque no han sido parte del capitalino desarrollado, son parcialmente parte de él y a partir de ahí ser enlace para un futuro comunismo o socialismo.

A partir de esta relación entre Marxismo e indigenismo, que en Bolivia se mira también como relación entre Marxismo y Movimientos Campesinos, ya que ambos colectivos trabajan la tierra y tienen un contacto directo con la naturaleza, se habla de un socialismo comunitario. Se trata de mirar las experiencias comunitarias de estos grupos para poder implementarlas en toda la sociedad boliviana. Experiencias de respeto a la naturaleza y a todos los seres humanos para construir así el socialismo del siglo XXI.

Mosonyi (2007) y García Linera (2010), ambos estudiosos de los indígenas, venezolano y boliviano, respectivamente, coinciden en descubrir que los indígenas no viven de imposiciones, sino más bien de consensos. Por lo que se deduce que invitar a los indígenas a ser parte del socialismo del siglo XXI, es respetar sus visiones sin interferir es sus procesos culturales ancestrales. Mosonyi (2007) resume en 10 puntos los aportes de los originarios venezolanos al socialismo del siglo XXI. Solamente citaremos un solo punto por razones de metodología de esta tesis ${ }^{29}$. Dice el nombrado autor:

Cuando discuten las propuestas de algún ente foráneo, generalmente algún organismo gubernamental, señalan con nítida precisión en cuáles aspectos existe pleno acuerdo o, por el contrario, cierto desacuerdo de mayor o menor gravedad según cada caso concreto y específico. No aceptan de buena gana las ofertas en bloque y menos aún si ya vienen previamente elaboradas o se les requiere la obediencia acrítica. Es fácil parlamentar con los indígenas si sus intereses son respetados y cuando prevalece un ánimo colectivo constructivo por ambas vertientes. (p. 189)

\footnotetext{
${ }^{29}$ Quien desee mirar todos los aportes, esta es la dirección electrónica: http://www.redalyc.org/articulo.oa?id=17721547010
} 
Con este aporte se da cuenta que los aborígenes saben más de lo que pensamos de ellos (de manera peyorativa y racista se llama indio a cualquier persona que ignora algo) para mantener su relación armónica entre ellos y la naturaleza y así ser parte de nuevo socialismo.

García Linera (2010) explica que el socialismo comunitario también se logra por acuerdos y respeto de la naturaleza:

...En el socialismo comunitario la naturaleza es parte imprescindible de la propia vida y se la tiene que cuidar con mayor fuerza y razón que la propia vida del ser humano. Si se genera riqueza, no será destruyendo la naturaleza sino preservándola para satisfacer necesidades [...] En lo político, en el socialismo comunitario, la sociedad política y la sociedad civil vuelven a fundirse gradualmente, esto quiere decir que un comunario, un joven, un estudiante, un campesino o un empresario se hacen partícipes directos de la toma de decisiones... (p. 16)

Es un socialismo democrático, protagónico de las ciudadanas y ciudadanos, participativo. No tiene nada de dictatorial para acusarlo como lo hacen ciertos mass media al servicio de los grandes capitales.

Los indígenas quieren soluciones concretas comunitarias y por eso la buscan de manera directa, sin discursos largos y con abstracciones como la filosofía occidental. Más allá de abstracciones respetables, el socialismo del siglo XXI se concreta en soluciones humanitarias. Dice Mosonyi (2007) de la manera de ser de los indígenas:

...Ellos quieren saber cuándo se les demarcarán las tierras, cómo se efectuará la mensura y hasta dónde llegará cada territorio colectivo, con sus lugares sagrados y los espacios necesarios para su movilización, ya que el conuco indígena trata de no agotar el suelo permaneciendo por largo tiempo e ininterrumpidamente en un solo sitio. También les interesa saber qué pasará con sus enfermos y cómo serán las escuelas oficiales, a fin de armonizarlas siquiera un poquito más con la cultura e idioma locales... (p. 187) 
El socialismo del siglo XXI con los aportes del indigenismo se convierte en un socialismo nuevo, que se puede implementar de manera democrática, sin lucha armada y puede coincidir con la emancipación de los seres humanos buscada por Marx.

\subsection{Campesinas, campesinos y socialismo del siglo XXI}

El punto del socialismo del siglo XXI e indígenas señaló la similitud, aunque no exacta, entre este movimiento y el de campesinas y campesinos por su relación directa con la tierra y toda la naturaleza: astros, lluvia, agua, animales, etc. Este apartado quiere resaltar los aportes de estos para así construir un socialismo del siglo XXI en un continente latinoamericano con presencia significativa de ellos.

Es mucho lo que contribuyen, sobre todo su conocimiento de agroecología y su capacidad de sembrar para el autoconsumo ${ }^{30}$, siendo una gran enseñanza para sembrar en los patios de las casas urbanas y terrenos urbanos, como forma de no depender del capital. Las campesinas y campesinos también aportan en su batalla por la tenencia de la tierra.

El socialismo del siglo XXI pretende respetar la naturaleza, y quienes saben de este respeto son precisamente las campesinas y campesinos por sembrar con técnicas agroecológicas para no dañar la tierra. También el socialismo promueve la solidaridad y ellos saben de compartir lo que cosechan, tienen conciencia de la generosidad de la tierra y por eso son generosos para compartir lo que producen. Fals Borda (2009) describe las características

\footnotetext{
${ }^{30} \mathrm{El}$ acuerdo de paz colombiano reconoce la economía campesina, familiar y comunitaria: "Desarrollo integral del campo: el desarrollo integral del campo depende de un adecuado balance entre las diferentes formas de producción existentes -agricultura familiar, agroindustria, turismo, agricultura comercial de escala-; de la competitividad y de la necesidad de promover y fomentar la inversión en el campo con visión empresarial y fines productivos como condición para su desarrollo; y de la promoción y fomento, en condiciones de equidad, de encadenamientos de la pequeña producción rural con otros modelos de producción, que podrán ser verticales $u$ horizontales y en diferente escala. En todo caso se apoyará y protegerá la economía campesina, familiar y comunitaria procurando su desarrollo y fortalecimiento." (p. 12)
} 
humanas de las campesinas y campesinos colombianos, específicamente del campo de Boyacá:

...el sentimiento de hospitalidad y simpatía, la constancia y la valentía en el esfuerzo, la objetividad en los aspectos prácticos de la vida, el sentido de la seguridad y del honor que se encuentran en las comunidades rurales, la solidaridad familiar, la honestidad, la fe en el Todopoderoso... (p. 36)

Estos valores sin duda son una base para construir un socialismo del siglo XXI como una forma de humanismo.

La lucha por la tenencia de la tierra es muy significativa en Colombia. Se puede decir que el conflicto armado colombiano finalizado con las Farc fue por la tenencia de la tierra. Las campesinas y campesinos de Colombia han sido desplazados y despojados de sus tierras. En el acuerdo de paz la Farc y el gobierno se propusieron transformar estructuralmente el campo, por este motivo ellos expresan uno los motivos del conflicto: el despojo de tierras. Dice este acuerdo, hablando de la transformación estructural del campo:

Que a juicio del Gobierno esa transformación debe contribuir a reversar los efectos del conflicto y a cambiar las condiciones que han facilitado la persistencia de la violencia en el territorio. Y que a juicio de las FARC-EP dicha transformación debe contribuir a solucionar las causas históricas del conflicto, como la cuestión no resuelta de la propiedad sobre la tierra y particularmente su concentración, la exclusión del campesinado y el atraso de las comunidades rurales, que afecta especialmente a las mujeres, niñas y niños. (p. 10)

También el acuerdo textualmente reconoce la violencia por la tenencia de la tierra de las campesinas y campesinos:

Regularización de la propiedad: es decir, lucha contra la ilegalidad en la posesión y propiedad de la tierra y garantía de los derechos de los hombres y las mujeres que son los legítimos poseedores y dueños, de manera que no se vuelva a acudir a la violencia para resolver los conflictos relacionados con la tierra. Nada de lo establecido en el Acuerdo debe afectar el derecho constitucional a la propiedad privada. (p. 13) 
Aunque en el acuerdo el gobierno colombiano no se compromete a una revolución socialista, la FARC como partido de izquierda quiere incorporar a los campesinos en su propuesta socialista. En la medida que se incorporen a las campesinas y campesinos al desarrollo de Colombia, estos podrán permear de socialismo a la sociedad colombiana, de manera pacífica y democrática como es el método del socialismo del siglo XXI, quiere decir, sin violencia.

No solo el despojo de tierras ha sido la causa del conflicto colombiano sino también las condiciones de vida de las campesinas y campesinos. Por eso en el acuerdo se propone la reforma agraria como salida al conflicto. Dice en su inicio, específicamente en el punto primero lo cual denota su importancia, que el conflicto colombiano ha sido por causa de la indiferencia para las campesinas y campesinos por parte del estado y la sociedad:

Los delegados y delegadas del Gobierno de la República de Colombia (el Gobierno Nacional) y las Fuerzas Armadas Revolucionarias de Colombia (FARC-EP), respecto a: 1. Hacia un Nuevo Campo Colombiano: Reforma Rural Integral. Consideran: Que en el marco del presente Acuerdo para la Terminación del Conflicto, la Reforma Rural Integral, en adelante RRI, sienta las bases para la transformación estructural del campo, crea condiciones de bienestar para la población rural - hombres y mujeres - y de esa manera contribuye a la construcción de una paz estable y duradera. Que a juicio del Gobierno esa transformación debe contribuir a reversar los efectos del conflicto y a cambiar las condiciones que han facilitado la persistencia de la violencia en el territorio... (p. 10)

Por eso Fals Borda (2009) explica de manera clara que tenencia de tierra de los campesinos sin acompañamiento de la sociedad y del estado para su desarrollo no tiene sentido: “...Debe subrayarse la opinión de que una verdadera reforma agraria no se reduce al problema de la tenencia o al uso 'económico' de la tierra, como ha habido la tendencia a considerar en Colombia y en otros países latinoamericanos...” (p. 53). 
Las campesinas y campesinos al ser incorporados de manera seria y practica al socialismo del siglo XXI son referencia obligada como protagonistas importantes, junto con los obreros e indígenas, motores de una economía al servicio del ser humano.

\subsection{Socialismo del siglo XXI y movimientos sociales}

Los movimientos sociales ${ }^{31}$, como lo indica su nombre son movimientos de la base de la sociedad que luchan y protestan por el reconocimiento de sus derechos ante un poder estatal y económico que se los quitan. Además de este motivo, surgen por el cansancio y el descontento por las clases políticas quienes se alejan de la base electoral. Otro motivo de la aparición de estos movimientos es una respuesta a una modernidad racional e individual. Dice Somuano Ventura (2007):

...Las explicaciones globales ven a los movimientos sociales y a las asociaciones civiles derivadas o ligadas a ellos como el resultado de profundos cambios en la sociedad en la que se generan y se desarrollan. En este sentido su explicación depende de diversas teorías de cambio social. Un representante de estas ideas es Jürgen Habermas, quien ve en los movimientos sociales una reacción a la creciente racionalización de la vida moderna. Claramente la industrialización y la urbanización supusieron un gran cambio en las formas de vida y en los esquemas mentales de mucha gente. Las instituciones tradicionales básicas como la familia, la comunidad, la religión, entre otras, se vieron fuertemente alteradas por lo que progresivamente se adoptaron nuevas formas de interrelación social con nuevos

\footnotetext{
31“Durante la segunda parte de los años noventa América Latina aparece atravesada por diferentes movimientos sociales de significación nacional. A manera de ejemplo podemos mencionar, entre otras experiencias, el levantamiento zapatista en la selva Lacandona en 1994 que hizo visibles las demandas de indígenas y campesinos cuando en México entraban en vigor los acuerdos de libre comercio con Estados Unidos; la "Guerra del Agua" cochabambina y las luchas del movimiento cocalero en el Chapare boliviano que les permitió alcanzar nuevos liderazgos, una significativa presencia en el parlamento y finalmente la elección de su líder como presidente de ese país; los levantamientos indígenas impulsados por la CONAIE en Ecuador en 1996 y en 2000 que culminan en ambos casos con la caída del gobierno; la emergencia y extensión del movimiento de trabajadores desocupados en Argentina y las movilizaciones y protestas que desencadenaron la renuncia del gobierno a finales de 2001; las iniciativas de ocupaciones de tierras masivas de carácter nacional acometidas por el Movimiento de Trabajadores Sin Tierra (MST) en Brasil; las movilizaciones campesinas en Paraguay que jugaron un rol importante en la caída del presidente Cubas Grau; las intensas protestas sociales en Perú (particularmente la experiencia de los Frentes Cívicos regionales) que marcaron el fin del régimen de Fujimori." (Somuano Ventura, 2007, p. 33)
} 
significados que, sin sustituir totalmente a las anteriores, se adecuaban mejor a las nuevas formas de organización generadas por la producción capitalista y la dominación legal burocrática. Los movimientos sociales hacen frente al rompimiento que sufren los vínculos tradicionales del individuo con su entorno social inmediato (de clase, familia y religión) y que dan lugar al alto grado de individualismo que, sin embrago, no conlleva la emancipación de todo tipo de control. (p. 34-35)

Son movimientos que expresan un aburrimiento de las instituciones tradicionales por lo que sus miembros deciden juntarse para hacer frente a los que los oprime. Entre tantos podemos resaltar el movimiento de los ecológicos, educación popular, de diversidad sexual, derechos humanos.

Estos movimientos junto con la clase trabajadora luchan por el socialismo del siglo XXI porque buscan equidad e inclusión en la sociedad. Guadarrama González (2012) enumera estos movimientos y resalta su fortaleza en América Latina:

En América Latina la clase obrera continua desempeñando un papel significativo en la lucha de clases, pero a la misma se le han sumado fuerzas imprescindibles de otros sectores marginados como los campesinos, indígenas, mujeres, minorías étnicas, migrantes y hasta sectores del lumpenproletariado, homosexuales, prostitutas, desempleados, etc., en la lucha contra el poder de las oligarquías vernáculas y transnacionales del capitalismo neoliberal, que en ocasiones pueden llegar a desempeñar un papel significativo en la dirección de las luchas sociales. (P. 588)

También Borón (2014) destaca a los movimientos sociales, a quienes se oponen la derecha y también algunos izquierdistas dogmáticos:

Parafraseando un célebre pasaje del Manifiesto Comunista podríamos decir que un fantasma recorre américa Latina. Es el fantasma del "giro a la izquierda" y una de sus más deplorables derivaciones: el populismo. Todas las fuerzas de la vieja y nueva derecha se unieron en santa cruzada para exorcizar a ese fantasma: en su tiempo fueron Condoleezza Rice y José M. Aznar, George W. Bush y Silvio Berlusconi; hoy son Barack Obama y Mariano Rajoy, mientras que los Vargas Llosa (padre e hijo) y Carlos Montaner, Jorge Castañeda y Andrés Oppenheimer, la Fundación Cubano-Americana y el National Endowment for 
Democracy, la Sociedad Interamericana de Prensa y los Reporteros sin Fronteras han estado envueltos en estas lides desde siempre. Todas estas vertientes se unen para rescatar a América Latina de la "mortal amenaza" que supone esta reorientación del rumbo político de la región. Y en esta confusa estampida se mezcla también un nutrido tropel formado por antiguos izquierdistas espantados ante los rostros insolentes de campesinos, indígenas, jóvenes, mujeres y el heteróclito "pobretariado" latinoamericano, que se rebelan con un protagonismo desconcertante para sus resecas teorizaciones... (p. 238)

La fuerza de estos movimientos es tal que el presidente Chávez en su propuesta socialista funda el Partido Socialista Unido de Venezuela (PSUV) como un partidomovimiento, para tomarlos en cuenta para la dirección política del mismo. Lo funda, para dejar de lado el burocratismo y así enraizarse en las realidades sociales de la gente y dar respuestas a las mismas desde sus aprendizajes, organizados en los movimientos sociales. Las líneas estratégicas de este partido explican de manera clara porque se une a los movimientos sociales:

...Optar por la lógica del Partido-Movimiento implica posicionarse dentro de las masas populares, estableciendo y desplegando una amplia política de alianzas con las diversas formas de organización popular, incluyendo los sectores patrióticos y democráticos de las clases medias, apoyándolas e invitándolas a poner su talento y conocimiento al servicio de la construcción de una sociedad del buen vivir para todos y todas. Es necesario establecer objetivos concretos, sobre el terreno, dentro del proceso real de transformación de la sociedad hacia el Socialismo. Se trata de trabajar junto con el pueblo, en su lucha diaria por transformar sus condiciones materiales de vida y la satisfacción de sus necesidades humanas [...] Esta política de alianzas con movimientos sociales, colectivos y organizaciones populares es apenas un primer paso para avanzar en el proceso de recuperación y rearticulación de fuerzas. Más allá, el objetivo es sumar para la causa revolucionaria a sujetos sociales y sectores de la población que se mantienen al margen de la política. ${ }^{32}$

Ante la experiencia del llamado socialismo real de la unión soviética con su carga burocrática, corrupta y elitista, los movimientos sociales son invitados a ser parte de la construcción del socialismo del siglo XXI. Esto con el objetivo de crear un estado socialista

\footnotetext{
${ }^{32}$ Líneas estratégicas de acción política del Partido socialista unido de Venezuela, Caracas, enero 2011Diciembre 2012. En: http://www.psuv.org.ve/portada/lineas-estategicas-de-accion-politica/\#.WZ3TwITyjIU
} 
centrado en el pueblo y no en los cargos de gobiernos o burocracia. De tal manera que se puede apostar a un estado comunal, un estado donde la gente, ella misma de manera organizada es la institución o estado socialista. Magallanes (2008) dice que las izquierdas de este siglo, y en especial en América Latina, no solo nacen de los trabajadores sino de la misma sociedad con sus clamores:

Tras el auge de las izquierdas habría también una visión de mayor confianza en la sociedad, que opone una visión 'sociocéntrica' en lugar de una 'estadocéntrica', común a muchas posiciones previas de izquierda e incluso de centroizquierda. Esta visión 'sociocéntrica' es la expresión en el ámbito ideológico de la constitución por estas izquierdas de frentes o alianzas amplias de fuerzas sociales, entre las que destacan los nuevos movimientos sociales y organizaciones no gubernamentales, que suplieran la debilidad del movimiento de los trabajadores. Aunque los nuevos movimientos sociales juegan un papel significativo también al interior de los movimientos socialistas en Europa, en nuestras sociedades latinoamericanas esto parece ser una necesidad, al tiempo que contribuye a ampliar los frentes sociales de izquierda e incluir a los sectores sociales de clase media dentro de acciones de crítica y transformación sociales. Ésta es quizás otra diferencia sustancial entre la izquierda latinoamericana y las características de la izquierda histórica europea, en la cual los trabajadores tuvieron una presencia más significativa. En América Latina, la participación del movimiento sindical ha sido más limitada, como quizás cabría esperar de una región industrialmente menos desarrollada en términos relativos, en la cual el sector informal y la economía de subsistencia tienen aún tanta importancia. (p. 38-39)

El socialismo del siglo XXI, aunque no se declara abiertamente estado comunal, propende hacia allá para que las comunidades y movimientos sociales asuman el mismo para dirigirlo. García Linera (2010) habla de un estado de movimientos sociales y comunitario o comunal:

Algunos analistas advierten que hay que evitar el surgimiento de una burguesía burocrática. Es una advertencia de la que hay que tener cuidado. La clave radica en que la toma de decisiones se socialice cada vez más, puede surgir una burguesía burocrática cuando las decisiones del Estado se concentran en un núcleo cerrado y exclusivo, que es lo que pasó en la Unión Soviética. La forma de combatir ello es que la toma de decisiones se democratice, se socialice, de ahí la importancia para nosotros de garantizar que seamos un gobierno y un Estado de movimientos sociales, porque de esa manera las decisiones de democratizan 
en la propia realidad. ¿Quién controla a los dirigentes?, son los movimientos sociales en su conjunto, las bases, niveles intermedios que renuevan a sus representantes, debaten las tomas de decisiones y definen el horizonte del país. Lo que pasó en Bolivia en estos últimos cuatro años es que las grandes decisiones de Estado como la nacionalización, Asamblea constituyente, reconversión comunitaria de la reforma agraria, seguro social, sin excepción, han sido debatidas, definidas, modificadas y mejoradas por la estructura de los movimientos sociales. Esa es la garantía de que no surja una élite que burocratice la toma de decisiones. A futuro, la garantía del socialismo comunitario radica en la democratización y comunitarización del Estado, de la toma de decisiones y del gobierno. Por eso en la Constitución, el mismo Presidente Evo hace énfasis en un gobierno de movimientos sociales, en la consulta con las bases y en el aprendizaje de ello para tomar decisiones en beneficio del país, que es justamente lo que no sucedió con otras experiencias de lucha revolucionaria en otras partes del mundo. (p. 16-17)

La participación de los movimientos sociales es fundamental para distinguir el socialismo del siglo XXI del socialismo del siglo XX.

\subsubsection{Movimientos ecológicos}

Los movimientos ecológicos son los movimientos sociales más mediáticos por bregar por un aspecto del mundo como es su futuro mediato y largo plazo en la conservación el medio ambiente. Ellos se preocupan por dar a las futuras generaciones un planeta limpio y con suficientes recursos para subsistir.

Aunque necesariamente todos los movimientos ecológicos no están identificados con el socialismo, estos indirectamente aportan a la propuesta del mismo, ya que el sistema opuesto que es el capitalismo es esencialmente destructor de la naturaleza por ser acumulador

de capital a costa de ella. Como ya se dijo, no todos los movimientos ecológicos son socialistas en teoría, pero en la práctica se ordenan hacia allá, al proponer y luchar por el uso 
respetuoso de los recursos naturales, el cuidado de los mares y océanos, hábitat natural de los animales, el uso de energía renovable, el reciclaje, la reducción del consumo de energía fósil, el reusar elementos para no ser desechados. Houtart (2009) explica lo destructor que es el capitalismo:

Existe una contradicción fundamental entre el hecho de que para el capital la biodiversidad sea una nueva frontera de acumulación, al mismo tiempo que su actuación práctica está destruyendo la fuente misma de su propia riqueza. Por una parte, los recursos no renovables son superexplotados: según el estudio Planeta Viva del WWF, en 2006, los seres humanos extraen un $25 \%$ más de los recursos que el planeta puede reproducir; en 2050, será el doble de la capacidad de reproducción de la tierra. Por otra parte, el monocultivo, sea de la soya, del eucalipto, de la palma africana, se realiza sobre extensiones enormes de tierra y destruyen la biodiversidad. Este tipo de actividad agrícola está dominado por empresas transnacionales, principalmente Monsanto o Cargill. (p. 56)

Estos movimientos ecológicos están íntimamente relacionados con los movimientos campesinos e indígenas, quienes luchan por el cuidado de sus tierras para su adecuado y de acuerdo con sus prácticas ancestrales. Houtart (2009) nombra algunos de los movimientos sociales ecológicos:

Varios movimientos sociales se encuentran en posiciones de resistencia. Se trata primero de los movimientos indígenas que luchan en el mundo entero. Hay unos 250 millones de personas que forman los pueblos autóctonos o, como se llaman en Asia, las minorías étnicas. Luchan por la integridad de su medio de vida, y conocemos muchos ejemplos en este sentido. Estas luchas se multiplicaron durante las últimas décadas. Basta pensar en los Zapatistas, en México, que entre otras cosas se oponen a la deforestación; en los indígenas del Kerala, con su defensa del agua contra la empresa Coca Cola; en los Karen de Tailandia, invadidos por el monocultivo de maíz de Monsanto; en los pueblos amazónicos, que se expresaron de manera muy clara en los Foros panamericanos de Belén y de Venezuela. Se puede añadir los movimientos campesinos que se organizan para defender una agricultura respetuosa de la biodiversidad, contra la agricultura productivista, y que luchan en un plan internacional. Es el caso en particular de Vía Campesina, una coordinación de más de 100 organizaciones en el mundo, que ha llevado una dura campaña contra los acuerdos de la OMC, en particular en Cancún y en Hong Kong. Se aprecia también una convergencia de 
movimientos a propósito de la defensa del entorno ecológico y la biodiversidad. Es el caso, por ejemplo, en Sri Lanka, de Monlar (Movement for Landreform), que reagrupó más de 100 organizaciones campesinas, obreras, religiosas, budistas y cristianas, contra la privatización de las selvas y contra las políticas del Banco Mundial. Debemos también añadir una acción muy eficaz y muy seria de algunas ONG especializadas, como el WWF o también la organización no gubernamental para la protección de los bosques tropicales, que tiene su sede en Montevideo. Poco a poco se aglutinan acciones en el mundo entero, no solamente contra las políticas destructivas del sistema económico, sino en favor de modelos alternativos que permitan el respeto al ambiente natural y la utilización de recursos renovables. (p. 59-60)

En el caso del socialismo comunitario de Bolivia, los movimientos ecológicos parten de los movimientos indígenas quienes tratan la naturaleza con consideración y devoción religiosa. Este es un caso de movimientos ecológicos-indígenas quienes apuestan al socialismo.

\subsubsection{Movimiento de la educación popular}

El movimiento social por la educación popular apunta hacia la inclusión de los sectores populares en la misma y hacia una educación critica, y por eso rechaza el capitalismo como forma de educación para la dominación y apoya el socialismo como forma de inclusión educativa y educación para la liberación. También orienta hacia una educación no solo institucional sino desde el hogar, las fábricas, los campos, desde la sabiduría propia de los pueblos, las comunidades organizadas o no.

Existen quienes por un lado hablan de movimientos sociales o de protesta social y por otro de educación popular olvidándose que la educación popular en sí misma es una protesta contra la exclusión de la escuela tradicional y por lo tanto puede considerarse a la educación popular un movimiento social. Mejía (1996) habla de la unión de los movimientos sociales y la educación popular: 
Estos dos fenómenos que se dieron como hecho cultural y político en los últimos 40 años en América Latina, forman parte, hacia el futuro, de una unidad indisoluble que no puede estar disociada de la nueva teoría de la impugnación que va surgiendo a lo largo del continente y que hoy apenas es visible en los estallidos del "Caracazo", Chiapas, los campesinos paraguayos, y Santiago del Estero en Argentina. Estos hechos piden a gritos una nueva teoría para interpretar esa organización que emerge desde la protesta y que requiere de procesos educativos que hagan posible una nueva forma de la lucha social en nuestra realidad. (p. 8788)

La educación popular como movimiento de protesta social siempre es critica a una educación para la dominación y está orientada hacia la liberación y al vencimiento del pensamiento colonial presente en sectores de las academias, desde la escuela inicial hasta la educación universitaria. Una educación académica que no valora la organización popular de los movimientos sociales; de aquí surge esa necesaria unión entre la educación popular y los movimientos sociales para lograr una academia cerca de los pueblos.

La educación popular necesariamente tiene que introducirse en la academia, para que desde dentro la transforme, y haga de la academia toda ella una gran trasformadora de la sociedad al darle acceso a la educación a toda la población sin ningún tipo de exclusión. Ella podrá realizar proyectos de aprendizaje que partan de los contextos, sociales, políticos, económicos, culturales, educativos, e históricos de los estudiantes, los cuales pueden ayudar bastante a implementar una sociedad socialista que ponga al ser humano en el centro y no al capital, como lo hace la educación para la dominación.

En Venezuela existe un proyecto educativo popular llamado "espacios de formación permanente para el desarrollo cultural endógeno" que toma en cuenta el estudio de los contextos para crear un currículo educativo pertinente: 
Las indagaciones de los contextos se basan en el levantamiento organizado y por escrito de los saberes y conocimientos producidos por las buenas prácticas que tienen los sujetos y que han sido invisibilizadas por la estructura y la gestión escolar. Esto nos permite un acercamiento verdadero hacia los seres humanos con los que contamos. En este sentido planteamos levantar los perfiles que tiene cada persona: 1. Saberes que traen los directivos, maestros y maestras, sujetos comunitarios, relacionados con su herencia cultural, es decir ligados a su origen, desarrollo social, económico, geográfico, familiar cultural, artísticos. 2. Otra situación similar se nos presenta en los y las jóvenes, adolescentes, niñas y niños que asisten a nuestros espacios. Si hacemos levantamientos de los saberes de ellos y ellas encontraremos una variedad y rica gama de legados culturales y artísticos que forman parte de su cotidianidad. 3. Saberes que tienen los obreros y obreras, secretarias. Entonces podemos decir que nuestros espacios educativos tienen en sí mismos, riqueza social y cultural, más allá de los contenidos programáticos y la estructura escolar, que expresan un currículo aun no explorado por nuestro sistema educativo, pero que está allí esperando ser reconocido. (Sojo, 2010, p. 7)

De esta manera la educación popular se orienta directamente al socialismo del siglo XXI en la incorporación de todos los saberes ancestrales políticos organizacionales, económicos y culturales necesarios para construirlo.

En Colombia existe un método de educación popular llamado "InvestigaciónAcción Participativa" (IAP). Es creado por Orlando Fals Borda, quien fue un sociólogo colombiano, con el objetivo de vincular al investigador en la solución de los problemas sociales. Y este buscar solución hace de la IAP un servicio educativo porque busca las causas y soluciones haciendo de la educación una práctica política y no neutra. Balcazar (2005) explica que es la IAP:

...El método de Fals-Borda estaba basado en la inserción del investigador en la comunidad, el análisis de las condiciones históricas y la estructura social de la comunidad, el desarrollo del nivel de conciencia de los miembros de la comunidad, el desarrollo de organizaciones políticas y grupos de acción y lo que ellos llamaron la investigación militante, caracterizada por su énfasis en la solución de problemas y el compromiso con la comunidad o grupo... (p. 61) 
Fals Borda (2009) por medio de la IAP hace un abordaje del conocimiento popular para hacer de este, fuente académica. Sin duda este método hace parte de la educación popular y es actual para el desarrollo de un socialismo desde abajo y desde la participación política de las comunidades y movimientos sociales:

En la investigación-acción es fundamental conocer y apreciar el papel que juega la sabiduría popular, el sentido común y la cultura del pueblo, para obtener y crear conocimientos científicos, por una parte; y reconocer el papel de los partidos y otros organismos políticos o gremiales, como contralores y receptores del trabajo investigativo y como protagonistas históricos, por otra... (p. 279)

\subsection{Trabajadoras, trabajadores y socialismo del siglo XXI como economía de equivalencias en una democracia participativa}

El socialismo del siglo XXI tiene un novedoso aporte con la incorporación de las nuevas trabajadoras y nuevos trabajadores, no solo los productivos, sino de todos aquellos que perciben salario, a cambio de la venta de su fuerza de trabajo, y que también se caracterizan por no ser dueños de los medios de producción donde trabajan.

Estas nuevas trabajadoras y nuevos trabajadores son quienes, entre otros, ejercen la labor de limpieza o aseo de los sitios de trabajos, por poner un ejemplo. Dejemos que Antunes (2008) los describa mejor, él dice de ellos:

...la clase trabajadora incorpora también al conjunto de los trabajadores improductivos, cuyas formas de trabajo son ejecutadas a través de la realización de servicios, sea para uso público, como los servicios tradicionales, sea para uso privado, para uso del capital, no constituyéndose, por eso, en elemento directo en el proceso de valorización del capital y de creación de la plusvalía... (p. 427) 
No son trabajadores directos creando riqueza y mercancía, pero están indirectamente sirviéndole al capital al recibir salario, y forman parte de los costos de la mercancía. García Linera (2010) también amplia el concepto de obrero a los intelectuales, a otros trabajadores, y a las clases medias:

...Aclaremos que obrero no es sólo el que usa overol, un intelectual o un científico también pueden ser obreros, un albañil, un textilero, un abogado, un sociólogo y clases medias, pequeños empresarios, pequeños propietarios y comerciantes que viven de su propia actividad pueden ser también obreros... (p. 12)

Estas trabajadoras y trabajadores también sufren las consecuencias del capitalismo por ser esclavos del horario de trabajo y ganar en muchos casos un ínfimo salario insuficiente para vivir dignamente. Por este motivo ellos también se les considera parte de la auténtica búsqueda de un sistema socialista del siglo XXI que reconozca su derecho a un salario digno, y es más, deben ser los primeros beneficiados de la producción donde ellos trabajan en el área de servicios.

Otro autor llamado Peters (citado por Dieterich, 2008) también amplia el concepto de trabajadora o trabajador más allá del trabajo productivo de plusvalía (proletario, obrero):

...Habrá que incluir en la teoría sobre el valor del trabajo todas las actividades humanas que trasciendan el autoabastecimiento del individuo. Se trata, ante todo, de actividades que hoy día se reúnen bajo el término "servicios": el trabajo que realizan los médicos, jueces, enfermeros, mecanógrafos, carteros, abogados, maestros, dirigentes de plantas industriales, operadores de camión, directores, barrenderos, cocineros, ministros, peluqueros, periodistas, tipógrafos; en pocas palabras, todas las actividades cuyos resultados no entran directamente a los bienes. (p. 77)

Estas nuevas trabajadoras y nuevos trabajadores que se incorporan al socialismo del siglo XXI lo hacen porque el trabajo vale por sí mismo y no por un precio producto de la 
oferta y la demanda, sino que los precios y salarios equivalen al trabajo mismo, y este, y toda mercancía o bien, y todo servicio producido es equivalente y valen lo mismo en cuanto si el número de horas trabajadas es similar. Esto puede ser posible en una economía equivalente en un socialismo del siglo XXI. Por lo que se requiere de una democracia directa de los ciudadanos que hagan valer su trabajo, la cual instaure esta economía equivalente imposible de ser concebida y menos practicada en una democracia representativa liberal burguesa aliada del capitalismo. La democracia liberal burguesa protege los intereses de los capitalistas, ya que los poderes del estado son controlados por los capitalistas. En una democracia participativa se camina hacia el socialismo ya que el control del pueblo garantiza la economía de equivalencias. En otras palabras, el pueblo en este tipo de democracia directa puede controlar la economía. Dieterich (2008) dice que esta democracia puede incidir en la economía:

El concepto "democracia participativa" se refiere a la capacidad real de la mayoría ciudadana de decidir sobre los principales asuntos públicos de la nación. En este sentido se trata de una ampliación cualitativa de la democracia formal, en la cual el único poder de decisión política reside en el sufragio periódico por partidos-personajes políticos. En la democracia participativa, dicha capacidad no será coyuntural y exclusiva de la esfera política, sino permanente y extensiva a todas las esferas de la vida social, desde las fábricas y los cuarteles hasta las universidades y medios de comunicación. Se trata del fin de la democracia representativa -en realidad sustitutiva- y su superación por la democracia directa o plebiscitaria. El parlamento y el sistema electoral de la partidocracia, como los conocemos hoy, son controlados por las elites económicas y no tendrán lugar en la democracia futura. Lo mismo es válido para los grandes monopolios de la adoctrinación (televisión, radio y prensa) y de la producción. La gran empresa privada -que en términos organizativos es una tiranía privada con estructura militar- es incompatible con una democracia real y desaparecerá como tal. (p. 93)

La democracia directa y participativa consiste en la participación del pueblo, de las comunidades, de la sociedad en general en las decisiones, de manera que la economía no sea guiada por la oferta y la demanda, la cual en una economía capitalista decide el precio de los bienes y servicios. En la democracia directa y participativa se quiere pasar de una economía de mercado a una economía equivalente o economía de equivalencias, donde los precios, como se ha dicho, son fijados por las horas de trabajo, para que así todo trabajo tenga el mismo valor, desde el trabajo del barrendero hasta el trabajo del gerente. Esta propuesta de 
Dieterich de una economía equivalente fruto de una democracia directa y participativa es una visión humanista de la democracia, de la economía y del trabajo. Se supera entonces el trabajo enajenado para dar paso a un trabajo humanizado que permita que los trabajadores puedan vivir dignamente y terminando de esta manera la división social del trabajo.

También se cuenta con un autor que incluye a nuevas trabajadoras y trabajadores en el socialismo del siglo XXI. Se trata de García Linera (2010) quien no lo dice directamente, pero propone juntar a los indígenas y campesinos, y obreros para el socialismo comunitario: quien afirma lo siguiente:

...Un brazo emerge del capitalismo desarrollado, el brazo obrero, y el otro, el brazo indígena emerge de lo que no fue destruido por el capitalismo. La ciencia y la tecnología, procedentes del capitalismo, y el mundo agrario comunitario, que resistió al capitalismo por 500 años, están aquí, pueden y deben irradiarse, expandirse y universalizarse. El socialismo comunitario será la comunidad agraria a nivel planetario, tenemos la semilla comunitaria que crecerá y dará frutos poderosos para Bolivia y para el mundo... (p. 17)

\subsection{Socialismo del siglo XXI construido desde abajo en los consejos comunales}

El socialismo desde abajo consiste en la participación del pueblo organizado en las decisiones del gobierno. Harnecker (2010) explica que la Constitución de la República Bolivariana de Venezuela orienta al socialismo del siglo XXI para ser construido desde la participación:

Lo que más llama la atención en la Constitución Bolivariana es el énfasis que allí se pone en la participación popular en los asuntos públicos y el hecho de que se subraye que este protagonismo es el que va a garantizar el pleno desarrollo, tanto de la persona como del colectivo. Aunque hay varios artículos de la Constitución que se refieren a este tema, probablemente el más completo es el artículo 62, donde se señala la forma en que este desarrollo se logra. Allí se dice que la "participación del pueblo en la formación, ejecución y control de la gestión pública es el medio necesario para lograr el protagonismo que garantice su completo desarrollo, tanto individual como colectivo", señalándose a continuación que es "obligación del Estado y deber de la sociedad facilitar la generación de las condiciones más favorables para su práctica”. Además, el artículo 70 señala otras formas que permiten al pueblo desarrollar "sus 
capacidades y habilidades": "la autogestión, cooperativas en todas sus formas [...] y demás formas asociativas guiadas por los valores de la mutua cooperación y la solidaridad". (p. 4)

En Venezuela existen los consejos comunales, los cuales son instancias de participación en la política de acuerdo con lo expresado por la constitución de la República Bolivariana de Venezuela de 1999, la cual dice en su preámbulo que la democracia venezolana es protagónica y participativa ${ }^{33}$. La máxima autoridad del consejo comunal es la asamblea de ciudadanos quienes por mayoría aprueban sus decisiones. Debe encargarse el consejo comunal de resolver las dificultades de su territorio. Normalmente cada Barrio (en Venezuela son sectores populares), sector, caserío rural, urbanización (en Venezuela son de clase de media) corresponde a un consejo comunal. Ellos tienen facultades también de producir bienes y servicios, de acuerdo con los avances de cada consejo comunal. Es una manera de vivir el socialismo porque parten de la solidaridad, de la preocupación por los vecinos. La experiencia ha sido positiva en muchos consejos comunales, ya que los mismos vecinos han construido su red de agua potable; otros han producido alimentos y luego vendidos a precios solidarios, otros han construido y reparado viviendas. Realizan en tiempos de vacaciones campamentos de recreación para niños y jóvenes. Lamentablemente existen experiencias negativas en las que algunos voceros ${ }^{34}$ de los consejos comunales obstaculizan por no ejercer bien sus

\footnotetext{
33 “El pueblo de Venezuela, en ejercicio de sus poderes creadores e invocando la protección de Dios, el ejemplo histórico de nuestro Libertador Simón Bolívar y el heroísmo y sacrificio de nuestros antepasados aborígenes y de los precursores y forjadores de una patria libre y soberana; con el fin supremo de refundar la República para establecer una sociedad democrática, participativa y protagónica, multiétnica y pluricultural en un Estado de justicia, federal y descentralizado, que consolide los valores de la libertad, la independencia, la paz, la solidaridad, el bien común, la integridad territorial, la convivencia y el imperio de la ley para esta y las futuras generaciones; asegure el derecho a la vida, al trabajo, a la cultura, a la educación, a la justicia social y a la igualdad sin discriminación ni subordinación alguna; promueva la cooperación pacífica entre las naciones e impulse y consolide la integración latinoamericana de acuerdo con el principio de no intervención y autodeterminación de los pueblos, la garantía universal e indivisible de los derechos humanos, la democratización de la sociedad internacional, el desarme nuclear, el equilibrio ecológico y los bienes jurídicos ambientales como patrimonio común e irrenunciable de la humanidad; en ejercicio de su poder originario representado por la Asamblea Nacional Constituyente mediante el voto libre y en referendo democrático, decreta la siguiente: CONSTITUCIÓN." Preámbulo de la Constitución de la República Bolivariana de Venezuela de 1999.
}

34 "Las personas electas para formar parte del consejo comunal se denominan voceras o voceros. Los militantes venezolanos se niegan, con razón, a utilizar el término de representante por las connotaciones negativas que este término ha adquirido en el sistema representativo burgués donde los candidatos sólo se acercan a las comunidades en tiempo de elecciones, prometen "todo el oro del mundo" y luego de electos nunca más se les 
funciones, y otros por no ser honestos en el manejo del dinero asignado por el gobierno y el dinero logrado por autogestión. Pero porque algunas experiencias sean negativas no se puede decir de manera determinante que las instancias de los consejos comunales sean instancias de ingobernabilidad.

El socialismo es mejor si es propuesto, consultado, deliberado, construido desde la base. He aquí la novedad del socialismo del siglo XXI. Un socialismo que no planifique con el pueblo tiene predestinado su fracaso como ocurrió con la Unión Soviética, la cual desde arriba planificaba. Un socialismo que se imponga también está destinado al fracaso, y si se mantiene a fuerza de represión, tarde o temprano se viene abajo. Nos encontramos en el estadio de la historia en lo que nada se impone. De aquí la importancia que la ética socialista sea consultada de lo contrario será moral socialista pero no ética socialista. Puede haber una moral, pero sin un sustento ético, porque no se hace por convicción sino por imposición. Y lo impuesto genera resistencia y no se hace por amor sino por sacrificio injusto con la correspondiente violación de los derechos humanos.

\subsection{Socialismo cristiano}

Heinz Dieterich citando a Chávez, quien propuso a partir de 2005 la invención del socialismo del siglo XXI, habla de un socialismo cristiano basado en las enseñanzas de solidaridad, no discriminación e igualdad de Jesús de Nazaret. Chávez (citado por Dieterich, 2008) decía entonces: “...Yo soy socialista de la nueva era, del siglo XXI y estamos planteándole al mundo revisar la tesis del socialismo cristiano. Si Cristo viniera aquí, fuera socialista, (el Libertador) Simón Bolívar iba directo al socialismo" (p. 9).

Dieterich (2008), quien analiza que el modo de producción descrito en los Evangelios es muy distinto al actual, afirma que las enseñanzas del Evangelio desde un punto de vista

\footnotetext{
ve. Por eso, la vocera o vocero que pierde la confianza de sus vecinas y vecinos - porque ha dejado de transmitir al consejo comunal lo que la comunidad piensa, decide, etcétera - debe ser revocada o revocado porque ha dejado de ser la voz de su comunidad." (Harnecker, 2010, p. 6)
} 
objetivo nada aportan para construir una economía del siglo XXI, por ser una economía industrial y de capitales. Sin embargo, entiende que haciendo una lectura distinta de la Biblia a los círculos integristas católicos se puede extraer enseñanzas para una economía del estado de bienestar, de distribución equitativa de la riqueza. Dieterich (2008), cita el Evangelio según san Juan, Cap. 2, que habla del milagro de Jesús de convertir unas seis tinajas llenas de agua en vino para repartir a los invitados a una boda; también cita un capítulo del Evangelio según san Marcos, específicamente el número 6, que cuenta de la multiplicación de cinco panes y dos peces, de tal manera que alcanzara para cinco mil hombres. Con estas dos citas de la Biblia, Dieterich (2008), recuerda que los cristianos no integristas apoyan una labor cristiana de compartir desde lo poco o mucho que tengan.

Según Dieterich (2008), Jesús quería una democratización de la riqueza en manos de los sumos sacerdotes, quienes habían convertido el templo de Jerusalén en un lugar de negocios para ellos solos. ${ }^{35}$ También quería Jesús una distribución equitativa de la riqueza y por eso era partidario de una reforma agraria para distribuir equitativamente la tierra, en medio de una economía agraria de la época del Jesús histórico. Y por último Jesús se proponía recuperar la soberanía de Israel, quien estaba oprimido por el imperio Romano. Así las cosas, podemos extraer que, según Dieterich (2008), Jesús tenía una visión del hombre desde la solidaridad, de un hombre con deber de transformar la sociedad patriarcal y esclavista, es decir, tenía la visión de un hombre libre para vivir en sociedad sin ser esclavizado, sino disfrutando de las riquezas de su trabajo. Jesús dice "el obrero merece su salario" (Evangelio según san Lucas, Cap. 10, 7); merece vivir de lo que trabaja, eso es lo justo. Para Dieterich (2008), Jesús es socialista, en cuanto que las primeras comunidades cristianas entendieron muy bien sus enseñanzas al vivir sin exclusiones, sin esclavitud y compartiendo todo lo que tenían sin que nadie pasara necesidad, y ganando la simpatía de la sociedad de entonces. El socialismo se conecta con la ética cristiana de la solidaridad. En el libro de los Hechos de los apóstoles, capítulos 2 y 4, se dice que en la primera comunidad cristiana o Iglesia primitiva

\footnotetext{
35 "Se acercaba la Pascua de los judíos y Jesús subió a Jerusalén. Y encontró en el Templo a los vendedores de bueyes, ovejas y palomas, y a los cambistas en sus puestos. Entonces hizo un látigo con cuerdas, echó a todos fuera del Templo, con las ovejas y los bueyes, desparramó el dinero de los cambistas y les volcó las mesas; y dijo a los vendedores de palomas: 'Quitad esto de aquí. No convirtáis la casa de mi Padre en un mercado.' " (Evangelio según San Juan, Cap. 2,13-16).
} 
nadie llamaba suyo a lo propio, ninguno sufría necesidad, compartían sus bienes, vendían lo que tenían y lo ponían a disposición de los apóstoles, repartían lo que tenían según la necesidad de cada uno. ${ }^{36}$

Dieterich (2008) explica muy bien estos dos capítulos diciendo:

Toda teoría de trasformación hacia una sociedad postcapitalista que se desarrolle "en concordancia con las ideas originales de Carlos Marx y Federico Engels", tiene que dar respuestas satisfactorias a los interrogantes y las incógnitas de los cuatro niveles existenciales del ser humano: el racional-critico, el estético, el ético y el cotidiano. La referencia a Jesús como un primer socialista es aplicable desde el plano ético de la praxis reformadora del Nazareno y de las convivencias sociales de las primeras comunidades cristianas, es decir, desde el tercer y cuarto nivel de la existencia humana (antropológica). Las primeras comunidades solían llamarse Ekklesia, tomando el termino y la praxis de las asambleas populares del sistema político de Atenas que era la primera democracia participativa en una sociedad de clase de Occidente, regida por una combinación de sistemas electorales y aleatorios (por sorteo); una democracia participativa que, sin embargo, no era universal, sino elitista, porque excluía a las mujeres, los metecos, esclavos y libertos. Según el apóstol Pablo, esas reuniones de la Ekklesia cristiana temprana eran aún más democráticas que su ejemplo griego, porque no tenían restricciones de admisión: "No hay más Judíos o Griegos, esclavos o libres, hombres o mujeres; porque todos son uno en Jesu Cristo". (p. 10-11)

\footnotetext{
36 Hechos de los apóstoles, Capitulo 2, versículos 41 al 47: "Los que acogieron la palabra de Pedro se bautizaron, y aquel día se unieron a ellos unas tres mil personas. Acudían asiduamente a la enseñanza de los apóstoles, a la convivencia, a la fracción del pan y a las oraciones. Toda la gente sentía un santo temor, ya que los prodigios y señales milagrosas se multiplicaban por medio de los apóstoles. Todos los que habían creído vivían unidos; compartían todo cuanto tenían, vendían sus bienes y propiedades y repartían después el dinero entre todos según las necesidades de cada uno. Todos los días se reunían en el Templo con entusiasmo, partían el pan en sus casas y compartían sus comidas con alegría y con gran sencillez de corazón. Alababan a Dios y se ganaban la simpatía de todo el pueblo; y el Señor agregaba cada día a la comunidad a los que quería salvar." Hechos de los apóstoles, Capitulo 4, versículos 32 al 37: "La multitud de los fieles tenía un solo corazón y una sola alma. Nadie consideraba como propios sus bienes, sino que todo lo tenían en común. Los apóstoles daban testimonio de la resurrección del Señor Jesús con gran poder, y aquél era para todos un tiempo de gracia excepcional. Entre ellos ninguno sufría necesidad, pues los que poseían campos o casas los vendían, traían el dinero y lo depositaban a los pies de los apóstoles, que lo repartían según las necesidades de cada uno. Así lo hizo José, un levita nacido en Chipre, a quien los apóstoles llamaban Bernabé (que quiere decir: 'El Animador'). Éste vendió un campo de su propiedad, trajo el dinero de la venta y lo puso a los pies de los apóstoles."
} 


\subsection{Socialismo Bolivariano}

El pueblo venezolano quiere construir el socialismo Bolivariano, partiendo de las ideas de Simón Bolívar. El Libertador de Venezuela, Colombia, Ecuador, Perú, Panamá y fundador de Bolivia, tuvo ideas que, si bien no pertenecen al socialismo científico, si están enmarcadas en la ética socialista. Bolívar (Citado por Cacciatore, 2010) en su discurso de Angostura, Venezuela, del 15 de febrero de 1819 decía que:

¡Legisladores! Yo deposito en vuestras manos el mando supremo de Venezuela. Vuestro es ahora el augusto deber de consagraros a la felicidad de la República: en vuestras manos está la balanza de nuestros destinos, la medida de nuestra gloria; ellas sellarán los decretos que fijen nuestra Libertad [...] El sistema de gobierno más perfecto es aquel que produce mayor suma de felicidad posible, mayor suma de seguridad social y mayor suma de estabilidad política. Por las leyes que dictó el primer Congreso tenemos derecho de esperar que la dicha sea el dote de Venezuela; y por las vuestras, debemos lisonjearnos que la seguridad y la estabilidad eternizarán esta dicha... (p. 199 y 208)

Esta idea de Bolívar puede tomarse para la construcción de una ética socialista. Porque si el socialismo busca la realización de un ser humano, entonces esta idea de Bolívar encaja para un sistema de gobierno, para una sociedad y un estado socialista. Se parece a lo que dice la Sagrada Escritura en el Evangelio de Juan: "mi paz les dejo, mi paz les doy"37, es decir, la paz que Dios da, ya que la paz es la mayor suma de bienes que da la felicidad ${ }^{38}$. Bolívar (Citado por Cacciatore, 2010) también en su discurso de Angostura abogaba por la libertad, la igualdad y la abolición de los privilegios en la sociedad, y estos son valores socialistas:

Un gobierno republicano ha sido, es, y debe ser el de Venezuela; sus bases deben ser la soberanía del pueblo: la división de los poderes, la libertad civil, la proscripción de la esclavitud, la abolición de la monarquía y los privilegios. Necesitamos de la igualdad para refundir, digámoslo así, en un todo, la especie de los hombres, las opiniones políticas y las costumbres públicas... (p. 208)

\footnotetext{
${ }^{37}$ Evangelio según san Juan, Capitulo 14, versículo 27.

38 "Saludo y despedida ordinaria de los de los judíos. Significa la integridad del cuerpo, luego la felicidad perfecta y la liberación aportadas por el Mesías. Todo esto lo da Jesús". (Biblia de Jerusalén p. 1531)
} 
El fin de la política para el Libertador es la felicidad y la libertad de los hombres y mujeres. Se nota un ánimo en el Libertador que le indica que la política es para la felicidad y alegría de los pueblos. Es una política que se abaja hasta lo concreto, por lo que quita esa visión popular aburrida de la misma (y por ser popular no es menos cierta).

En Venezuela desde 1998 se vive un proceso político llamado "revolución bolivariana", porque se basa en la recuperación y aplicación del ideario bolivariano. Proceso que tuvo sus antecedentes en el llamado Caracazo de febrero de 1989, caracterizado por saqueos a supermercados, debido al acaparamiento de los alimentos y como protesta a un paquete de medidas neoliberales impuestas por el presidente de entonces Carlos Andrés Pérez. Y luego fue seguido por el movimiento militar contra el presidente Pérez, liderado por Hugo Chávez Frías, jefe del Movimiento Bolivariano 200 (MBR 200), un movimiento de militares con ideas bolivarianas y socialistas. Aunque Bolívar no se llamó así mismo socialista ${ }^{39}$ su ideario enlaza con esta idea suprema de organización social. Y partir de este proceso revolucionario se reflexiona sobre la necesidad de construir un socialismo a lo venezolano, por la cercanía de la mayoría del pueblo humilde a esta "revolución bolivariana" y viceversa.

\footnotetext{
${ }^{39}$ Guadarrama González (2012) dice que las ideas de Bolívar tuvieron impacto en lo social: "Bolívar no llegó a escribir obras propiamente filosóficas, pero en todo su epistolario, en numerosos documentos, proclamas, etc., se aprecian innumerables reflexiones de profundo carácter filosófico respecto a los más diversos problemas, entre ellos la existencia de Dios, las potencialidades de la naturaleza, el conocimiento humano, el poder de la ciencia, el papel de las artes, de la moral y de las ideas en el desarrollo social, entre otras. En ellas se aprecia tanto su concepción particular del lugar de la filosofía en el saber humano, como la recepción creadora que hay en él de las ideas de la ilustración y en general si ideario profundamente humanista" ( $\mathrm{p}$ 244-245). También se puede agregar que Bolívar no fue un filósofo en el sentido académico pero sus reflexiones expresan posturas filosóficas, por lo que hace críticas a las ideas que no correspondían a la realidad de su momento (crítica a los gobiernos coloniales) , o para decirlo en clave marxista: ideas sin realidad. Dice Bolívar (Citado por Guadarrama González, 2012) : "los códigos que consultaban nuestros magistrados, no eran los que podían enseñarles la ciencia práctica del gobierno, sino los que han formado ciertos buenos visionarios que, imaginándose republicas aéreas, han procurado alcanzar la perfección política, presuponiendo la perfectibilidad del linaje humano. Por manera que tuvimos filósofos por jefes, filantropía por legislación, dialéctica por táctica, y sofistas por soldados. Con semejante subversión de principios y de cosas, el orden social se resintió extremadamente conmovido, y desde luego corrió el estado a pasos agigantados a una disolución universal, que bien pronto se vio realizada" (246).
} 


\subsection{Socialismo e interculturalidad}

La interculturalidad se refiere al dialogo entre culturas como pares y no como superiores unas de otras. A partir de esta comunicación intercultural surge la filosofía intercultural como método de búsqueda de la verdad no imponiendo sino encontrando puentes para una filosofía más humanista y por ende en favor del desarrollo de los pueblos a partir de su propia filosofía o pensamiento. Fornet-Betancourt (2001) dice lo que significa la filosofía intercultural:

Esa nueva figura de la filosofía, la "filosofía intercultural", será nueva, primero, en el sentido de que será una manera de hacer y practicar la filosofía que brota de lo inédito. O sea, que no se trata de una simple reubicación teórica de lo que tenemos ni de una radicalización de planteamientos heredados. Se trata más bien de crear desde las potencialidades filosóficas que se vayan historizando en un punto de convergencia común, es decir, no dominado ni colonizado culturalmente por ninguna tradición cultural. Segundo, es la "filosofía intercultural" porque, superando los esquemas de la filosofía comparada, apunta a la realización de la filosofía en el sentido de un proceso continuamente abierto en el que se van dando cita, se van con-vocando y van aprendiendo a con-vivir las experiencias filosóficas de la humanidad toda. Con otras palabras: es un proceso eminentemente polifónico donde se consigue la sintonía y armonía de las diversas voces por el continuo contraste con el otro y el continuo aprender de sus opiniones y experiencias. (p. 29)

Tomando en cuenta este concepto podemos hablar entonces de un socialismo del siglo XXI intercultural, porque no solo se basa teóricamente y en la praxis de Marx y las experiencias sociales reales, sino con el contraste, las opiniones, y las experiencias socialistas propias de cada cultura que va construyendo y autocriticando este nuevo socialismo.

Se nutre el socialismo del siglo XXI de las diversidades presente en América Latina y no en una formula dogmática a ser impuesta. Por este motivo hablamos de un socialismo indígena, obrero, de diversidad sexual, campesino, de movimientos sociales distintos. Estas disimilitudes permiten una libertad frente a la opresión del capitalismo uniformador, que, si bien hoy en día se puede disfrazar de respetuoso con las culturas, ha querido imponer un único modelo económico, irrespetando por lo tanto la diversidad económica y política de las culturas. 
Anteriormente se habló de la interculturalidad del socialismo al hablar del socialismo indígena, campesino, de los movimientos sociales, de la participación de la mujer, de los nuevos trabajadores y de los trabajadores de siempre, es decir, la clase obrera. Ahora se hablará del aspecto teórico de la filosofía intercultural y como ella permite un socialismo abierto a la diversidad. Fornet-Betancourt (2004) dice que esta filosofía no sólo busca el eco de una cultura en otra, sino en una solidaridad con la otra cultura, lo que permite un socialismo que no solo lucha por la cultura obrera, sino que se solidariza con las situaciones de injusticia en otras culturas y movimientos sociales o humanos:

...De esta suerte la filosofía intercultural, en tanto que figura de un filosofar contextual, se propone como la expresión de una filosofía que - abundando en su idea de la autocomprensión - considera la toma de responsabilidad contextual como una condición necesaria para abrirse a un dialogo de diversidades donde, superándose actitudes tautológicas y/o la disposición a escuchar solo la resonancia que produce la palabra propia en el otro, se aprenda a compartir diferencias y a solidarizarse con ellas en la carne cultural y corporal del otro; es decir, donde se aprende a ser universales compartiendo contextualidades. (p. 131)

De tal manera que un socialismo es un universal en la medida que cada contexto de lucha social se hace universal en relación y sin imposición al otro. En otras palabras, cada contexto de por si es universal porque aporta al mundo, ya es parte de un todo. Por ende, el socialismo es contextual en contraposición al capitalismo uniformador por querer forjar una sola cultura. Y también lo es por buscar ese encuentro de identidades, es como una mezcla de ellas, pero en su respectivo contexto sin que ocurra la dilución de este. Dice Fornet-Betancourt (2004):

Debe notarse, sin embargo, que con este rechazo de la exigencia de coherencia la filosofía intercultural no aboga por la hibridez de las culturas o identidades, que las convertiría en constructos sin perfil definido y sin arraigo contextual, sino que plantea más bien la alternativa de una universalización que ciertamente mezcla las identidades, pero sin diluirlas porque se da en términos de un proceso de acompañamiento contextual que les permite mantener su base contextual-material como hilo conductor de sus transformaciones (p. 141-142) 
La filosofía intercultural juntamente con el socialismo hace una ética crítica frente a las víctimas de las injusticias. Fornet-Betancourt (2004) dice que la filosofía intercultural es una filosofía para nuestro tiempo, porque se sitúa en el hoy, y desde esta realidad temporal que no es patrimonio de todos hace su llamado para que sea propiedad colectiva:

Conviene añadir, para que también quede claro de entrada, que esa toma de posición ética que implica la interculturalidad se refiere concretamente a la opción de fondo por ver lo que sucede en nuestro tiempo con los ojos de los y las que son víctimas de las "realidades" que genera el aparato dominante de nuestro tiempo. De donde se sigue que la caracterización de la filosofía intercultural como una "filosofía para nuestro tiempo" debe leerse también en el sentido de una indicación sobre la dimensión programática que conlleva su "actualidad". Pues la opción ética mencionada tiene como consecuencia para la "actualidad" de la filosofía intercultural actualizarse justo como una filosofía que muestra que eso que llamamos "nuestro tiempo" es un tiempo que no toda la humanidad puede conocer como un tiempo realmente suyo en el que se ocupa de lo que verdad le conviene e importa. "Filosofía para nuestro tiempo" quiere decir así para la filosofía intercultural compromiso histórico con la tarea de hacer que nuestro tiempo sea nuestro, con un nuestro que pueda ser pronunciado por toda la humanidad como manifestación de copertenencia solidaria... (p. 132)

Esto quiere decir que el socialismo del siglo XXI es intercultural y de esto se deduce que es para todas las culturas, todas las mujeres y hombres del mundo, no solo es exclusivo para un grupo. Y será de completo en la medida que todas y todos participen de la justicia económica.

La filosofía intercultural y el socialismo del siglo XXI van a reconstruir las realidades culturales desde los contextos para así superar la invasión epistemológica central europea producida por el capitalismo. Dice Cuellar (2017): “...Es un volver a la voz de los pueblos desde una campaña de alfabetización en los muchos mundos que tenemos. Estamos analfabetos por tantas interpretaciones que han terminado por descontextualizar nuestras realidades históricas.” (p. 542) Es revalorizar nuestros contextos y desde ahí descubrir los valores socialistas inmersos en ellos. Este es el reto del socialismo del siglo XXI, que no está construido del todo, sino que es un proceso dialectico sin fin, lo que permite renovarlo y actualizarlo siempre. 
Finalmente, en este apartado, se puede afirmar que el socialismo del siglo XXI se sirve de la filosofía intercultural para ver las culturas latinoamericanas de igual a igual a las de los otros continentes. De esta manera si puede construir la convivencia sana, respetuosa entre seres humanos, que defienden su identidad en primer lugar, que están abiertos a los aportes antropológicos y humanistas de otras culturas y respetan lo diverso. Esto es socialismo del siglo XXI.

\subsection{Socialismo del siglo XXI e integración latinoamericana}

El socialismo del siglo XXI es integrador de lo latinoamericano. Nace premisamente acá, como se ha dicho, en Venezuela, Bolivia, Ecuador, en la década primera de este siglo, en el contexto de ascenso al poder de presidentes en consonancia con movimientos sociales, interculturales y obreros. En esta misma década asumen en Brasil, Lula, en Argentina los esposos Kirchner, en Paraguay el obispo católico Lugo, en Nicaragua Daniel Ortega, en Uruguay el frente amplio con Tabaré Vásquez y el carismático líder Pepe Mujica, en Honduras el derrocado Zelaya por un golpe militar auspiciado por Estados Unidos, y los jefes de gobiernos de los países caribeños. Todos ellos contribuyeron a darle fuerza a la integración latinoamericana con la fundación de la Celac en 2012 y Unasur en el año 2008. Aunque no todos ellos son representantes del socialismo del siglo XXI, han contribuido enormemente a su planteamiento teórico práctico al favorecer la integración, objetivo indispensable del socialismo. Sin integración de los pueblos de América Latina es imposible construir un socialismo que pueda enfrentarse al monstruo del capitalismo bien unido en la Unión Europea y bien armado para la guerra por Estados Unidos.

La idea de integración nace de pensadores y héroes como Bolívar, Miranda, Martí, entre otros más. Bolívar propone el congreso anfictiónico de Panamá como manera practica la unión americana. Dice Acevedo (2011): 
El sueño americanista de Bolívar se va a expresar en términos concretos en dos grandes proyectos políticos: la Gran Colombia y el Congreso Anfictiónico de Panamá. El primer proyecto, el Libertador pretende la formación de confederaciones lo suficientemente sólidas en lo económico, político, demográfico, militar, etc., para poder enfrentar los peligros que por lógica asedian a las pequeñas republicas, bien sea por causas externas como la invasión de potencias extranjeras o el perfilamiento de caudillos y dictadores oligárquicos y plutocráticos. En este último aspecto, Bolívar hacia predicciones de que la experiencia política e histórica americana le daría más tarde la razón. Para Bolívar, países como Argentina y Perú estaban llamados a establecer dictaduras (p. 54).

Bolívar (En Cacciatore, 2010) propone este grandísimo sueño para fortalecer las naciones de América y también invita a Gran Bretaña para encontrar un aliado más allá de estas fronteras:

El congreso de Panamá reunirá a todos los representantes de la América y un agente diplomático del gobierno de su majestad británica. Este congreso parece destinado a formar la liga más vasta, o más extraordinaria o más fuerte que ha aparecido hasta el día sobre la tierra. La Santa Alianza será inferior en poder a esta confederación, siempre que la Gran Bretaña quiera tomar parte en ella, como miembro constituyente. El género humano daría mil bendiciones a esta liga de salud y la América como la Gran Bretaña cogerían cosechas de beneficios. Las relaciones de las sociedades políticas recibirán un código de derecho público por regla de conducta universal. (p. 295)

Miranda es otro gran soñador, pero por soñador no deja de ser práctica esta idea de unión americana. Dice Acevedo (2011):

En sus años de lucha en Europa, se apropia del discurso de Viscardo y llama a los americanos a la unión para enfrentar a España. A él se debe la idea de la formación de un gran bloque continental llamada "Colombia" o "Colombeia", que sirvió de influencia al pensamiento de Bolívar. Como intelectual representa el antecedente más importante en el proceso de integración y solidaridad hispanoamericana. América y los americanos representan el núcleo de su reflexión y pensamiento político. (p. 53). 
Martí nos habla en "Nuestra América" de la identidad como americanos. Y esa originalidad crea su unidad. Dice Laguna Gómez (2011):

...Sucesor en línea directa del ideario bolivariano, Martí irá a desarrollar en este texto una crítica categórica a la actitud de pose de las clases dominantes al desatender alevosamente el llamado de la originalidad americana e imitar siempre todo lo extranjero. Los acusará de cobarde e indignos por no atreverse "a descubrir" el maravilloso espesor de la sociedad y la cultura latinoamericana y llegar a sentir vergüenza en ellas. En "Nuestra América", como lo hará en buena parte de su monumental obra, Martí desmontará con argumentos sólidos esa vergüenza para transformarla en orgullo patriótico. Se preguntará: “¿En qué patria puede tener un hombre más orgullo que en nuestras republicas dolorosas de América?" (p. 114-115)

Sin duda que la integración Latinoamérica conlleva a profundizar su identidad o identidades y así se puede construir un socialismo original del siglo XXI a lo latinoamericano o lo que es lo mismo a lo indígena, campesino, femenino. 


\section{Encuentros teóricos entre el socialismo del joven Marx y el socialismo del siglo XXI}

Este capítulo conclusivo precisará los encuentros teóricos entre el socialismo del joven Marx y el socialismo del siglo XXI. Se va a poner a dialogar a ambos socialismos para revelar que ha heredado, que parte del espíritu de Marx, que visión del hombre y proyecto emancipatorio del joven Marx está contenido en el socialismo del siglo XXI. Finalmente se resaltará la importancia del socialismo del siglo XXI hablando de lo novedoso, lo cual no fue abordado por Marx por no estar presente en su época.

\subsection{Dialogo de ambos socialismos}

Dialogar no es una tarea fácil, siempre es una tarea compleja porque implica renunciar a que no se tiene la verdad absoluta y descubrir en el interlocutor verdades que no se han visto $^{40}$ y llegar al encuentro y superar el enfrentamiento, siempre necesario este último en algunos casos. Con el socialismo del joven Marx sucede lo mismo, es una tarea lenta, serena y compleja ponerlo a dialogar con el socialismo del siglo XXI. Se trata de encontrar que ambos socialismos caminan por un mismo hilo conductor: la emancipación del ser humano.

El socialismo del siglo XXI, más que una superación es una continuación del socialismo del Joven Marx, ya que en su época no se había desarrollado un feminismo, ecologismo, movimientos de educación popular, movimientos campesinos e indígenas. Estos últimos

\footnotetext{
${ }^{40}$ Como reza el dicho popular: "Cuatro ojos ven más que dos".
} 
fenómenos del socialismo del siglo XXI, sin duda son prolongación de la lucha emancipatoria comenzada por Marx.

El joven Marx desarrolla de manera exquisita el tema de la alienación del ser humano al trabajar y no poder disfrutar del producto del mismo. Dramáticamente en sus escritos de 1844 denuncia el maltrato de los obreros y obreras de su época por trabajar muchas horas y solo comer para sobrevivir y así, el capital poder perpetuar la clase obrera explotada. Es un trabajo mediante el cual pierde el objeto del mismo y no se realiza como humano. Dice Marx (2013):

Hasta tal punto aparece la realización del trabajo como desrealización del trabajador, que éste es desrealizado hasta llegar a la muerte por inanición. La objetivación aparece hasta tal punto como perdida del objeto que el trabajador se ve privado de los objetos más necesarios no solo para la vida, sino incluso para el trabajo. Es más, el trabajo mismo se convierte en un objeto del que el trabajador sólo puede apoderarse con el mayor esfuerzo y las más extraordinarias interrupciones. La apropiación del objeto aparece en tal medida como extrañamiento, que cuantos más objetos produce el trabajador, tanto menos alcanza a poseer y tanto más sujeto queda a la dominación de su producto, es decir, del capital. (p. 135)

El socialismo del siglo XXI denuncia al igual que el joven Marx la visión del ser humano maquina extrañado de la mercancía producida y del capital producido. Es una denuncia que emancipa al ser humano. Por este motivo propone la participación de las trabajadoras y trabajadores como consejos que puedan administrar las empresas para redistribuir la riqueza de acuerdo con la necesidad humanas de ellos y de sus esfuerzos correspondientes. Peters (Citado por Dieterich, 2008) lo plantea teóricamente en una economía de equivalencias:

Los países comunistas, igual que los capitalistas [...] sólo pueden realizar históricamente el regreso a la economía equivalente a un nivel superior, si combinan la teoría sobre el valor del trabajo con el principio de la equivalencia. Entonces, el salario equivaldrá al tiempo de trabajo invertido, independientemente de la edad, del sexo, del estado civil, del color de la piel, de la nacionalidad, del tipo de trabajo, del esfuerzo físico, de la preparación escolar, 
del desgaste, de la habilidad, de la experiencia profesional, de la entrega personal al trabajo; independientemente también, de la pesadez del trabajo y de los peligros que implique para la salud. En pocas palabras: el salario equivale directa y absolutamente al tiempo laborado. Los precios equivalen a los valores, y no contienen otra cosa que no sea la absoluta equivalencia del trabajo incorporado en los bienes. De esta manera se cierra el circuito de la economía en valores, que sustituye a la de precios. Se acabó la explotación de los hombres por sus prójimos, es decir, la apropiación de los productos del trabajo de otros, por encima del valor del trabajo propio. Cada ser humano recibe el valor completo que él agregó a los bienes o a los servicios. (p. 76-77)

Y esta economía de equivalencias es posible en una democracia participativa que garantice la de las trabajadoras y trabajadores organizados, como ya se dijo, en consejos. He aquí un encuentro teórico entre ambos socialismos y la vez una pequeña diferencia. Mientras que el Joven Marx invita a una toma del poder del proletariado con la llamada dictadura del proletariado, que no debe entenderse como un poder despótico sino un paso previo al control democrático de la economía, el socialismo del siglo XXI es igual a una democracia participativa. Ahora bien, este socialismo no solo incorpora a trabajadoras y trabajadoras ${ }^{41}$ sino también a indígenas y campesinos para que su trabajo no sea enajenado. Y es entendible esta diferencia de incorporación de actores históricos porque en la época de Marx el centro era el proletariado industrial, y esta época del socialismo del siglo XXI los centros no son solos los obreros sino todo aquel que trabaje incluyendo a las clases medias, como lo dice García Linera (2010):

...Las clases medias y el empresariado van asumiendo que sus intereses, su vida, sus recursos y su bienestar se garantizan de mejor manera asociándose, aliándose tomando en cuenta el liderazgo del movimiento indígena y del obrero. En la hegemonía de estos hermanos que lideran, convocan, seducen y logran acuerdos con estos otros sectores, se juega la vía democrática socialista, el tránsito pacífico sin necesidad de enfrentarnos. Habrá tensiones pero no grandes confrontaciones... (p. 17-18).

\footnotetext{
41 Llámese trabajadoras y trabajadores a todo el que participe directa o indirectamente a la producción de riqueza, por lo que se incluyen quienes trabajan en las áreas de servicios de las empresas, como la limpieza y transporte, por ejemplo. Ellos tienen derecho a disfrutar de la mercancía que se produce: alimentos, calzados, vestidos, etc.
} 
Se ha escrito, que más que superación del socialismo del siglo XXI sobre el socialismo del joven Marx se puede hablar de continuación, ya que en la época de Marx no había movimientos sociales emancipadores y feministas exactamente iguales a los de ahora, son contextos distintos. Otro encuentro teórico, aunque pequeño (en el caso del joven Marx), es la valoración de la mujer en los escritos del Joven Marx y en socialismo del siglo XXI.

El joven Marx toma en cuenta a la mujer al decir que la relación del hombre con la naturaleza nace de su relación con la mujer. Es decir, la mujer es tan naturaleza como el hombre, es decir, es igual de importante su presencia en el mundo. Marx (2013) citando a Shulz resalta la independencia de la mujer en el mundo obrero, aunque explotada también, es trabajadora como el hombre:

En las hilaturas inglesas están actualmente ocupados sólo 158.818 hombres y 196.818 mujeres. Por cada 100 obreros hay 103 obreras en las fábricas de algodón del condado de Lancaster y hasta 209 en Escocia. En las fábricas inglesas de lino, en Leeds, se contaban 147 obreras por cada 100 obreros; en Druden y en la costa oriental de Escocia, hasta 280. En las fábricas inglesas de seda...muchas obreras; en las fábricas de lana, que exigen mayor fuerza de trabajo, más hombres...También las fábricas de algodón norteamericanas ocupaban, en 1833, junto a 18.593 hombres, no menos de 38.927 mujeres. Mediante las transformaciones en el organismo del trabajo le ha correspondido, pues, al sexo femenino, un circulo más amplio de actividad lucrativa..., las mujeres una posición económica más independiente..., los dos sexos más aproximados en sus relaciones sociales. (p. 79-80)

En el socialismo del siglo XXI se pone a la mujer con el mismo liderazgo del hombre, ya que lo social no es solo masculino, sino también femenino, además de ser homosexual, bisexual y transgénero. No es exclusividad de un género. Es un colectivo como un todo, producto de las sumas de las partes. No es solo una parte, por eso lo social es el todo. Cada uno con su diferencia e individualidad, pero respetando la postura sexual del otro, aunque no se este acuerdo. Blanco (2007), quien hace una autocrítica al movimiento feminista socialista de Venezuela habla de la autonomía de las féminas en la creación de un poder de ellas en confrontación dialéctica permanente del poder de los hombres: 
...si damos por entendido que el movimiento de mujeres yace únicamente al interno de los partidos políticos y se busca cada vez más su unidad en un solo aparato, esto es, que las mujeres sigan haciendo la política de ellos, al servicio de ellos, y postergando reiteradamente su propia lucha, entonces no es muy difícil prever el resultado, ni hace falta ser pitonisas - que lo somos- para darnos cuentas de que vamos directo al fracaso, al menos de nuestro socialismo. Considero que el camino nuestro pasa por la idea de la formación, del debate, del proceso de producción de conocimiento que transforme nuestra realidad. No creo que mientras deleguemos nuestro poder -ya sea al partido, al líder, al marido- y no demos un paso para la búsqueda y la conquista de nuestra autonomía y no podamos reencontrarnos en nuestra inmanencia como sujetas de la polis tan iguales como ellos, tan fraternas como ellos, pero sobre todo tan diferente como nosotras. Esto pasa por reinventar una forma de hacer política, errar y descubrir nuevos caminos preñados de una pedagogía política y de una militancia creativa. (p .95)

Es la diferencia de ellas con respecto a los hombres, la que pueden crear una comunidad socialista que aporte desde lo femenino, de lo materno, de la agudeza y disciplina propia y distintiva de la mujer para organizar y desarrollar una sociedad. Son ellas mismas de manera autónoma las que pueden crear un socialismo feminista sin delegación en los hombres.

Un tercer encuentro entre ambos socialismos es la historia materialista que podemos encontrar en ellos. Los obreros son protagonistas de la historia materialista presentada por el Joven Marx. Los movimientos sociales, indígenas, campesinos, junto con los obreros son protagonistas de esta historia.

La historia desde las realidades materiales es el aporte del joven Marx. Primero la realidad y luego la reflexión, para que esta última responda y pueda guiar la realidad para que pueda ser mejor cada día, más justa y más humana. Realidad que se concreta en comida, bebida, ropa, vivienda, educación, arte, deporte y todo lo demás que se necesita para vivir. Marx y Engels (2010) dicen que el primer hecho de la historia es:

...la creación de los medios para la satisfacción de estas necesidades, la producción de la vida material misma, y precisamente éste es un hecho histórico, una condición básica de toda historia, que aún hoy en día, tal como hace mil 
años, tiene que realizarse cada día y cada hora simplemente para mantener vivos a los seres humanos... (p. 53)

Porque existen estas necesidades reales y no creadas para vivir, la historia se mueve a partir de ellas para analizar si han estado cubierta para todos los humanos o solo para un grupo, y a partir de esto Marx y Engels dirán que la historia es la "historia de la lucha de clases", quienes pugnan por dominar lo producido para vivir. Y esta lucha de clases “...es una lucha política..." (Marx y Engels, 2007, p. 19) por tomar el poder. A este materialismo histórico también se le llama dialéctica materialista, porque la historia se mueve por el dialogo entre lo material y la idea.

El socialismo del siglo XXI es la nueva fuente para una historia de las realidades sociales. Y es fuente también para la dialéctica materialista de Marx. Se debe entender que en el periodo histórico de Marx no se daba estas realidades que hace que el socialismo del siglo XXI aglutine no solo la clase obrera, sino también la clase media, los estudiantes y otros movimientos sociales impactados negativamente por el capitalismo. En la época de Marx no existía una clase media como la nuestra, la cual es fruto de los procesos políticos sociales, quien debe estar también a la vanguardia y extender sus logros también a la clase obrera. Ella esta llamada junto con los obreros a ser parte del socialismo del siglo XXI. Guadarrama González (2012) explica muy bien porque no solo el proletariado moderno debe derrotar el capitalismo:

La creciente complejidad de la estructura socioclasistas de las sociedades dependientes, como las predominantes en los países latinoamericanos, obliga -a la hora de establecer alternativas de orientación socialista a los países de esta región- a tomar en consideración también otras clases y grupos sociales, como la empobrecida clase media, la pequeña burguesía, el estudiantado, la intelectualidad e, incluso, los militares, que sufren de modo diferente las consecuencias del capitalismo real y el impacto de su crisis contemporánea. (p. 589)

Se observa entonces, como las realidades que articula el llamado socialismo del siglo XXI inciden en una transformación de ideas para una historia materialista o materialismo 
histórico, que pueda hacer una sociedad socialista de derechos humanos respetados con una producción de riquezas repartida en beneficios de todas y todos. En otras palabras, el socialismo del siglo XXI es la unión de los movimientos sociales, indígenas, campesinas y campesinos, obreras y obreras, mujeres. Primero son los pueblos con sus líderes naturales y luego las ideas. ${ }^{42}$ Esto es la dialéctica materialista del siglo XXI.

El cuarto dialogo teórico entre el Joven Marx y el socialismo del siglo XXI es la irrupción del indigenismo latinoamericano. El marxismo del Joven Marx pone en el centro de la revolución al obrero ${ }^{43}$. Nos preguntamos ¿cómo entender un socialismo del siglo XXI indigenista con quienes no son obreros y quienes no han pasado por una previa revolución industrial proletaria burguesa para llegar al socialismo? La respuesta la podemos encontrar en García Linera y Stefanoni, quienes respectivamente hablan de una subsunción del mundo económico y social al capitalismo y de una analogía entre obreros e indígenas.

García Linera (2008) habla de "La teoría del desarrollo del capitalismo como proceso de subsunción formal y de subsunción real del proceso de trabajo bajo el capital” (p. 117). Es una de las teorías de la crítica marxista, que, según este autor, acerca al marxismo con el indigenismo. Esta teoría explica como el capitalismo ha desplegado su poder para subsumir o absorber todo el aparato económico del mundo desde el más pequeño al más grande, a partir de su desarrollo. Quiere decir que manera indirecta o directa el capitalismo lo asume todo. Cuando un campesino o indígena produce, así no sea de manera industrial sino artesanal, este producto al venderlo toma forma de capital y de ganancia. Dice García Linera (2008):

\footnotetext{
42 Chávez decía: "señores yo no soy la causa, soy la consecuencia" (recuperado de: http://www.oas.org/es/centro_noticias/comunicado_prensa.asp?sCodigo=C-095/13). Son primeras las luchas de unos pueblos irrespetados en sus derechos humanos y luego las reflexiones que surgen para guiar a estos mismos pueblos. La llamada Revolución Bolivariana, de la cual surge el Chavismo como ideología política es consecuencia no causa.

${ }^{43}$ Marx y Engels (2007) en el manifiesto comunista explican el papel de la clase obrera en la transformación revolucionaria de la sociedad: "El proletariado se valdrá de su dominación política para ir arrancando gradualmente a la burguesía todo el capital, para centralizar todos los instrumentos de producción en manos del estado, es decir, del proletariado organizado como clase dominante, y para aumentar con la mayor rapidez posible la suma de las fuerzas productivas." (p. 33)
} 
Este proceso de subsunción nos dice Marx, tiene dos etapas, la subsunción formal y la subsunción real. ¿En que consiste la supeditación formal, sobre cuya base se levanta la subsunción real? Hay subsunción formal -o mejor, la expansión primaria del capitalismo- cuando los intercambios, el comercio y los negocios entre productores se subordinan a la lógica del mercado, a la lógica de la ganancia mercantil. Eso comenzó a ocurrir alrededor de 1400 y de allí, gradualmente, el intercambio mercantil entre productores no-capitalistas, pero que van asumiendo una lógica del comercio capitalista que se comienza a expandir por el mundo. El primer resultado de esta lógica de expansión de la lógica mercantil es la creación del mercado mundial, que se redondea con el llamado descubrimiento de América, la vinculación entre el comercio entre California con China, China con la India y Europa y nuevamente con América Latina; lo que podíamos llamar la primera etapa de la globalización, la creación del mercado mundial que comienza a ser una realidad desde 1490-1500. (p.118119)

Según García Linera ya Marx se apuntaba hacia un socialismo no solo de base proletaria y burgués sino hacia todo movimiento histórico no capitalista como el indígena y el campesino. Llama la atención que el Manifiesto comunista señala a los estamentos no proletarios en orden hacia allá. Dice Marx y Engels (2007):

Los estamentos medios -el pequeño industrial, el pequeño comerciante, el artesano, el campesino-, todos ellos luchan contra la burguesía para salvar de la ruina su existencia como tales estamentos medios. No son, pues, revolucionarios, sino conservadores. Más todavía, son reaccionarios, ya que pretenden volver atrás la rueda de la historia. Son revolucionarios, únicamente por cuanto tienen ante sí la perspectiva de su tránsito inminente al proletariado, defendiendo así no sus intereses presentes, sino sus intereses futuros, por cuanto abandonan sus propios puntos de vista para adoptar los del proletariado. (p. 20-21)

Y se puede señalar que la historia lineal planteada por Marx también puede ser vista cuando indígenas son subsumidos por el capital y por lo tanto empiezan a ser parte del mundo obrero porque también trabajan en función del capital y no son beneficiados de las ganancias. Para Stefanoni el partido Movimiento al Socialismo del Bolivia propone muy bien el concepto pueblo en semejanza con los indígenas. Ya no solo es la clase trabajadora la que sufre los efectos del capital sino todo el pueblo. Dice Stefanoni (2008): 
En cuanto sujeto político, para el MAS no es la clase sino el pueblo, y no en el sentido marxista -un pueblo hegemonizado por una clase- sino en el sentido populista: el pueblo se construye como equivalencia de las demandas de quienes se oponen a la oligarquía en una suerte de alianzas de clases... (257-258)

Entonces los indígenas como pueblo pueden estar al lado de la clase trabajadora y clases medias para construir una nación pluriétnica. En este sentido los indígenas se nivelan a la clase trabajadora descrita por Marx.

Volviendo al punto de la subsunción formal y real del indigenismo por parte del capitalismo, García Linera dice que la subsunción real consiste, como ya se ha dicho, en una producción no necesariamente industrial ligada al poder del capital. Dice García Linera (2008):

...la subsunción real supone la subordinación de la actividad creativa, de la actividad emotiva de la fuerza del trabajo a los intereses del capital. No solamente las emociones, el intelecto, la imaginación, la creatividad quedan subordinadas a la empresa, sino que la propia actividad asociativa de los trabajadores, sus propias iniciativas colectivas, sus propias iniciativas de aglomeración y de agrupación quedan por último subordinadas al capital. Este es el momento final y último de la subsunción real, porque el capitalismo llega a subsumir una fuerza productiva infinita. El intelecto es una fuerza productiva infinita y la emoción es una fuerza productiva infinita. En ese momento, cuando el capitalismo subsume esto, ha logrado redondear y totalizar su proceso de producción sobre bases propias, se vuelve universal, se vuelve planetario y se vuelve total. (p. 120)

Para finalizar este punto de los encuentros teóricos, es interesante citar a Stefanoni, quien viene a confirmar lo que se viene señalando de la articulación de entre el marxismo y los movimientos sociales, indígenas y obreros. Este es un gran encuentro teórico entre marxismo del joven Marx y el socialismo del siglo XXI. Dice Stefanoni (2008):

A riesgo de simplificar la complejidad que conlleva esta confederación de organizaciones sindicales, indígenas y sociales -y consciente del reduccionismo de los conceptos- podríamos definir el MAS como un nuevo nacionalismo en el que los clivajes pueblo-oligarquía y nación-imperialismo están atravesados por 
una cierta etnificacion (no excluyente) de la política. En el campo de los referentes históricos del MAS se procesa la misma articulación: Tupac Amaru, Tupac Katari, Bartolina Sisa, el Che Guevara, el sacerdote progresista Luis Espinal, y el diputado socialista Marcelo Quiroga Santacruz, ambos asesinados por la dictadura de García Meza en 1980, conviven en la misma iconografía masista. (p. 258)

\subsection{Importancia y novedad del socialismo del siglo XXI}

El socialismo del siglo XXI es importante por responder a la dura existencia de los más pobres de este siglo. A partir de la caída del muro de Berlín y del fin del socialismo real en la antigua Unión Soviética solo queda $\mathrm{Cuba}^{44}$, China, Vietnam y Corea del Norte con un sistema por lo menos en teoría de incorporación de las masas empobrecidas a la sociedad. Y con el poder de los mass media ufanándose del bien del capitalismo y la crueldad del comunismo, este queda contra la pared, por no tener defensa mediática. En este contexto surge el socialismo del siglo XXI, como nuevo por no querer continuar las contradicciones del socialismo real y ser impulsado por la vía electoral.

América Latina es pionera del socialismo del siglo XXI, por proponerse enfrentar al imperio de los Estados Unidos. En Abya yala como llaman los indígenas nuestros a este continente se viene dando esta batalla por poner en primer lugar a los sin nombres olvidados por el sistema capitalista. El socialismo del siglo XXI viene a dar protagonismo y participación a tantos socialistas anónimos, que sin saberlo unos, otros sin querer llamarse así, en la práctica viven el socialismo desde el compartir y la solidaridad. A esta novedosa teoría y práctica se agrega la teología de la liberación, que con su método ver juzgar y actuar quiere demostrar que el Evangelio libera las comunidades oprimidas por la guerra, el despojo de tierras, la falta de servicios básicos, etc. Sectores de la Iglesia Católica se animan a colaborar, aunque sea calladamente por miedo a la presión jerárquica, por el principio de

\footnotetext{
44 El socialismo cubano va más allá de la teoría por su atención gratuita de la salud y su misión medica internacional reconocida por el mundo entero.
} 
subsidiaridad de la doctrina social de la Iglesia. Este principio anima a apoyar iniciativas sociales de la base, de la cual hace parte el socialismo del siglo XXI. Dice este principio:

El principio de subsidiaridad protege a las personas de los abusos de las instancias sociales superiores e insta a estas últimas a ayudar a los particulares y a los cuerpos intermedios a desarrollar sus tareas. Este principio se impone porque toda persona, familia y cuerpo intermedio tiene algo de original que ofrecer a la comunidad. La experiencia constata que la negación de la subsidiaridad, o su limitación en nombre de una pretendida democratización o igualdad de todos en la sociedad, limita y a veces también anula, el espíritu de libertad y de iniciativa. ${ }^{45}$

Juan Pablo II, hoy declarado santo por la Iglesia Católica dijo en una entrevista que el marxismo contiene semillas de verdad ${ }^{46}$. Este Papa, quien fue un gran oponente al comunismo de su país y época, pudo reconocer la bondad de la teoría comunista de Marx. Tanto así que visitó a Cuba con la intención de abrirla al mundo y que el mundo se abriera a cuba. Se debe agregar que el llamado Papa anticomunista en la encíclica Sollicitudo rei sociales habla de la índole social de la propiedad privada quitando lo absoluto de la misma ${ }^{47}$. Con este aporte se abrió a una idea de socialización de los medios de producción.

\footnotetext{
${ }^{45}$ Recuperado de: http://www.vatican.va/roman_curia/pontifical_councils/justpeace/documents/rc_pc_justpeace_doc_200605 26_compendio-dott-soc_sp.htmI\#IV. EL PRINCIPIO DE SUBSIDIARIDAD

46 Juan Pablo II (1993) decía: “...Era legítimo combatir el sistema totalitario, injusto, que se definía socialista o comunista. Pero también es verdad lo que dice León XIII, es decir, que hay 'semillas de verdad' incluso en el programa socialista. Es obvio que no se deben destruir estas semillas, que no deben perderse. Hoy es necesario realizar un análisis preciso y objetivo, pero también hay que saber discernir. Los protagonistas del capitalismo a ultranza tienden a desconocer incluso las cosas buenas realizadas por el comunismo: la lucha contra el desempleo, la preocupación por los pobres..." (recuperado de https://elpais.com/diario/1993/11/02/internacional/752194817_850215.html)
}

47 “Es necesario recordar una vez más aquel principio peculiar de la doctrina cristiana: los bienes de este mundo están originariamente destinados a todos. El derecho a la propiedad privada es válido y necesario, pero no anula el valor de tal principio. En efecto, sobre ella grava 'una hipoteca social', es decir, posee, como cualidad intrínseca, una función social fundada y justificada precisamente sobre el principio del destino universal de los bienes. En este empeño por los pobres, no ha de olvidarse aquella forma especial de pobreza que es la privación de los derechos fundamentales de la persona, en concreto el derecho a la libertad religiosa y el derecho, también, a la iniciativa económica. " (Juan Pablo II, 1987, recuperado de http://w2.vatican.va/content/johnpaul-ii/es/encyclicals/documents/hf_jp-ii_enc_30121987_sollicitudo-rei-socialis.html) 
El socialismo del siglo XXI no es la solución máxima, pero si una luz en el túnel de injusticias productos de guerras en nombre del dominio del dinero. Es tal el temor ante las propuestas humanistas de este socialismo que Donald Trump no quiere seguir relaciones estables diplomáticas con Cuba y amenaza a Venezuela con una invasión militar. Como dijo Fidel la historia me absolverá, solo ella podrá juzgar la eficacia y bondad del socialismo del siglo XXI.

Las preguntas siguen abiertas ¿Si el socialismo del siglo XXI fracasa, esto significará el fracaso de la teoría? ¿Será que el capitalismo podrá ceder a sus intereses y cobrar sola la ganancia necesaria? La labor filosófica nunca se detendrá porque la dialéctica nunca se cerrará. A seguir filosofando desde la realidad para seguir transformándola para el bien común. 


\section{Referencias bibliográficas}

Acevedo Gutiérrez, A. (2011). América Latina nacionalidad e integración. En R. Antolinez Camargo y F. Santamaría Velasco (comp.), La integración de América Latina y el Caribe filosofía, geopolítica y cultura (pp. 37-68). Bogotá: Universidad Santo Tomas.

Acuerdo final para la terminación del conflicto y la construcción de una paz estable y duradera (2016).

Recuperado de:

http://www.altocomisionadoparalapaz.gov.co/procesos-yconversaciones/Documentos\%20compartidos/24-11-2016NuevoAcuerdoFinal.pdf

Aguirre Rojas, C., (2010). La historiografía en el siglo XX. Bogotá: Ediciones Desde Abajo.

Antunes, R. (2008). La nueva morfología del trabajo y el diseño multifacético de las luchas sociales. En J. Estrada Álvarez (comp.), Izquierda y socialismo en América Latina (pp. 425432). Bogotá: Universidad Nacional de Colombia. 
Balcázar, F., (2005). Investigación acción participativa (iap): aspectos conceptuales y dificultades de implementación.

Recuperado de:

https://ebookcentral.proquest.com/lib/bibliotecaustasp/detail.action?docID=3163434

Barrios Romero, A. (2007). Sociedad igualitaria aborigen. Recuperado de:

https://www.aporrea.org/ideologia/a39406.html

Blanco, J. (2007). Al debate feminismo revolucionario y socialismo. En el marco de la construcción del socialismo del siglo XXI (Venezuela). Revista Venezolana de Economía y Ciencias Sociales (2), 87-102.

Bohórquez, C. (2013). Los límites del imperio, la Revolución Bolivariana y el Socialismo del Siglo XXI. Recuperado de:

http://biblioteca.clacso.edu.ar/gsdl/cgi-bin/library.cgi?c=ve/ve028\&a=d\&d=article18239oai

Borón, A. (2014). El socialismo del siglo xxi: breves notas sobre algunas experiencias recientes, y otras no tan recientes, de América Latina. Recuperado de: http://biblioteca.clacso.edu.ar/clacso/se/20140918020441/ReinventarLaIzquierda.pdf

Bosteels, B., (2016). Marx y Freud en América Latina. Política, psicoanálisis y religión en tiempos de terror. Madrid: Akal. 
Botero Uribe, D., (2004). Discurso sobre el humanismo. Recuperado de:

http://ebookcentral.proquest.com/lib/bibliotecaustasp/detail.action?docID=3201081

Bunge, M. (2010). ¿Existió el socialismo alguna vez, y tiene porvenir? Lecciones y Ensayos (88), 17-41.

Cacciatore, G. y Scocozza, A., (2010). El gran majadero de la historia: Simón Bolívar, pensamiento político y constitucional. Bogotá: Planeta.

Chávez, H. (2006). El discurso de la unidad. Recuperado de: http://www.manuelugarte.org/modulos/biblioteca/c/chavez/chavez.htm

Constitución de la República Bolivariana de Venezuela (1999). Recuperado de: http://www.mpptaa.gob.ve/publicaciones/leyes-y-reglamentos/constitucion-de-la-republicabolivariana-de-venezuela

Correa, A. (01 de mayo de 2007). Intervención del Presidente de la República, Rafael Correa, por el día del trabajo. Recuperado de: http://www.presidencia.gob.ec/wpcontent/uploads/downloads/2013/09/2007-05-01-Discurso-por-el-D\%C3\%ADa-delTrabajo.pdf

Cuellar, G., (2017). La clave de la intersubjetividad, una mirada intercultural para la enseñanza de la historia. Recuperado de: https://es.scribd.com/document/360012142/Caminos-en-la-ensenanza-de-la-Historia 
Cumare M; Izaguirre M. y Sojo M. (2010) Los maestros (as) y sus prácticas en el devenir histórico latinoamericano y caribeño. Pedagogía de la Acción y Reflexión. Recuperado de: https://es.scribd.com/document/66549620/Los-Maestros-Epdcue

Dieterich, H. (12 enero de 2017). Gobierno y oposición son igualmente incapaces. Panorama. Recuperado de: http://www.panorama.com.ve/experienciapanorama/Heinz-Dieterich-a-PANORAMAGobierno-y-oposicion-son-igualmente-incapaces-20170112-0001.html

Dieterich, H. (2008). Hugo Chávez y el socialismo del siglo XXI (2a. ed.). Recuperado de:https://ebookcentral.proquest.com/lib/bibliotecaustasp/reader.action?docID=3175591\&q uery=Dieterich

Engels, F. y Marx, K. (2010). La ideología alemana (I). En K. Marx, La ideología alemana (I) y otros escritos filosóficos (21-178). Buenos Aires: Losada, S.A.

Fals Borda, O., (2009). Una sociología sentipensante para América Latina. Recuperado de: http://biblioteca.clacso.edu.ar/clacso/se/20100617103320/fborda.pdf

Fornet-Betancourt, R., (2004). Filosofar para nuestro tiempo en clave intercultural. Recuperado de: http://www.casadelcorregidor.pe/descarga/Fornet_Filosofar_en_clave_intercultural.pdf 
Fornet-Betancourt, R., (2001). Transformación intercultural de la filosofía. Bilbao:

Desclee de Brouwer.

Foro de sao paulo, Declaración final (2016). Recuperado de:

http://forodesaopaulo.org/declaracion-final-del-xxii-encuentro-del-foro-de-sao-paulo-sansalvador-2016/

Foro de sao paulo, Declaración final (2017). Recuperado de:

http://forodesaopaulo.org/declaracion-final-del-xxiii-encuentro-del-foro-de-sao-paulomanagua-2017/

Freire, P., (1970). Pedagogía del oprimido. México: Siglo XXI Editores.

Fromm, E., (1962). Marx y su concepto del hombre. México: Fondo de Cultura Económica.

García Cuadrado, J., (2010). Antropología filosófica: una introducción a la filosofía del hombre. Recuperado de:

http://ebookcentral.proquest.com/lib/bibliotecaustasp/detail.action?docID=3207763

García Linera, A. (2010). El socialismo comunitario. Un aporte de Bolivia al mundo. Recuperado de: http://www.vicepresidencia.gob.bo/IMG/pdf/revista_analisis_5.pdf 
García Linera, A. (2008). Marxismo e indianismo. Recuperado de:

http://biblioteca.clacso.edu.ar/Panama/cela/20120717093956/marxismo.pdf

Guadarrama González, P. (2012). Humanismo real, positivo y concreto, justicia social, derechos humanos y/o eficiencia económica: Retos para el socialismo en el siglo XXI. En J. Estrada Álvarez (comp.), América Latina en disputa: Reconfiguraciones del capitalismo y proyectos alternativos (pp. 565-594). Bogotá: Universidad Nacional de Colombia.

Guadarrama González, P. (2012). Pensamiento filosófico latinoamericano. Humanismo, método e historia. Bogotá: Planeta.

Harnecker, M. (junio de 2010). Democracia, participación y socialismo en Venezuela: Una mirada crítica. Ponencia presentada en evento "Democracia, participación y socialismo" organizado por la Fundación Rosa Luxemburgo en Quito. Recuperado de: http://rebelion.org/docs/111544.pdf

Houtart, F., (2009). El camino a la utopía desde un mundo de incertidumbre. Recuperado de: http://biblioteca.clacso.edu.ar/clacso/coediciones/20100629020520/houtart.pdf

Juan Pablo II (2 de noviembre de 1993). El cristianismo fue determinante en la caída del comunismo. El País. Recuperado de: https://elpais.com/diario/1993/11/02/internacional/752194817_850215.html 
Juan Pablo II (1987). Sollicitudo rei sociales. Recuperado de http://w2.vatican.va/content/john-paul-ii/es/encyclicals/documents/hf_jp-

ii_enc_30121987_sollicitudo-rei-socialis.html

Katz, C. (2014). Laboratorio de otro socialismo. En A. Piqueras (ed.), Claves para

construir el socialismo del siglo XXI: II curso de verano de la academia de pensamiento crítico (pp. 55-79). España: El Viejo Topo.

Korsh, K., (1978). Marxismo y filosofía. Barcelona: Ariel.

Laguna, A. (2011). El germen de la identidad latinoamericana en nuestro pensamiento político. En R. Antolinez Camargo y F. Santamaría Velasco (comp.), La integración de América Latina y el Caribe filosofía, geopolítica y cultura (pp. 101-117). Bogotá: Universidad Santo Tomas.

Líneas estratégicas de acción política del Partido socialista unido de Venezuela (2012).

Recuperado de:

http://www.psuv.org.ve/portada/lineas-estategicas-de-accion-politica/\#.WZ3TwlTyjIU

Leopold, D., (2012). El joven Karl Marx. Filosofía alemana, política moderna y realización humana. Madrid: Akal.

Lugones, M. (2008). Colonialidad y Género. Tabula Rasa (9), 73-101. 
Magallanes, R. (2008). Del socialismo del siglo XIX a la propuesta de un socialismo para el siglo XXI.

Recuperado de:

http://biblioteca.clacso.edu.ar/gsdl/cgi-bin/library.cgi?c=ve/ve-

004\&a=d\&d=17721699003oai

Marcuse, H. (1971). Nuevas fuentes para fundamentar el materialismo histórico.

En H. Marcuse, Para una teoría critica de la sociedad (pp. 9-72). Caracas: Tiempo Nuevo.

Marx K. y Engels F., (2007). Manifiesto comunista. Caracas: Monte Ávila Editores Latinoamericana, C.A.

Marx, K. (2010), Ad Feuerbach. En K Marx, La ideología alemana (I) y otros escritos filosóficos (pp. 11-19).Buenos Aires: Losada, S.A.

Marx, K., (2013). Manuscritos de economía y filosofía. Madrid: Alianza Editorial. S.A.

Mejía, M., (1996). Reconstruyendo la transformación social. Movimientos sociales y educación popular. Bogotá: Cooperativa Editorial Magisterio.

Molano Camargo, F. (2008). Socialismo del siglo XXI o Socialismo en el siglo XXI: Un estado de la cuestión. En J. Estrada Álvarez (comp.), Izquierda y socialismo en América Latina (pp. 141-148). Bogotá: Universidad Nacional de Colombia. 
Mondolfo, R., (1977). El humanismo de Marx. México: Fondo de Cultura Económica.

Monedero J. C. (2008). Hacia una filosofía política del socialismo del siglo XXI. Notas desde el caso venezolano. Recuperado de:

http://www.redalyc.org/articulo.oa?id=40306805

Monedero. J. C. (2014). Socialismos en el siglo xxi. La experiencia de América Latina. Recuperado de:

http://biblioteca.clacso.edu.ar/clacso/se/20140918020441/ReinventarLaIzquierda.pdf

Montes del Castillo, A., (2009). Ecuador contemporáneo: análisis y alternativas

actuales. Recuperado de:

http://ebookcentral.proquest.com/lib/bibliotecaustasp/detail.action?docID=4776042

Mosonyi E. (2007). El socialismo indígena en tanto componente del socialismo del siglo XXI: Una metaética trascendental y milenaria. Recuperado de:

http://www.redalyc.org/articulo.oa?id=17721547010

Pachón Soto, D. (2013). Los manuscritos de Marx de 1844 y las filosofías de la vida. Aquelarre (23), 31-46.

Pontificio Consejo Justicia y Paz (2004), Compendio de la doctrina social de la Iglesia.

Recuperado de:

http://www.vatican.va/roman_curia/pontifical_councils/justpeace/documents/rc_pc_justpea ce_doc_20060526_compendio-dott-soc_sp.html 
Rodríguez. E., (1985). Marx y América Latina. El problema de las interpretaciones.

Bogotá: El Búho.

Somuano Ventura, M. (2007). Movimientos sociales y partidos políticos en América Latina: una relación cambiante y compleja. Recuperado de:

http://biblioteca.clacso.edu.ar/gsdl/cgi-bin/library.cgi?c=mx/mx-024\&a=d\&d=26702703oai

Stefanoni, P. (2008). Bolivia, el nacionalismo indígena como identidad política. En J. Estrada Álvarez (comp.), Izquierda y socialismo en América Latina (pp. 253-260). Bogotá: Universidad Nacional de Colombia.

Suardía, P., (2001). Antropología general. Recuperado de:

http://ebookcentral.proquest.com/lib/bibliotecaustasp/detail.action?docID=3186872 